\title{
The Lindi Formation (upper Albian-Coniacian) and Tanzania Drilling Project Sites 36-40 (Lower Cretaceous to Paleogene): lithostratigraphy, biostratigraphy and chemostratigraphy
}

\author{
Álvaro Jiménez Berrocoso ${ }^{1}$, Brian T. Huber ${ }^{2}$, Kenneth G. MacLeod ${ }^{3}$, Maria Rose Petrizzo ${ }^{4}$, Jacqueline A. Lees ${ }^{5}$, \\ Ines Wendler ${ }^{6}$, Helen Coxall ${ }^{7,8}$, Amina K. Mweneinda ${ }^{9}$, Francesca Falzoni ${ }^{4}$, Heather Birch ${ }^{10}$, Shannon J. Haynes ${ }^{3}$, \\ Paul R. Bown ${ }^{5}$, Stuart A. Robinson ${ }^{11}$, Joyce M. Singano ${ }^{9}$ \\ ${ }^{1}$ Repsol Exploración, Méndez Álvaro 44, Madrid 28045, Spain. E-mail address: alvaro.jimenez.b@repsol.com \\ ${ }^{2}$ Department of Paleobiology, MRC 121, Smithsonian Museum of Natural History, Washington, DC 20013-7012, USA \\ ${ }^{3}$ Department of Geological Sciences, University of Missouri, Columbia, MO 65211, USA ${ }^{4}$ Dipartimento di Scienze della Terra "Ardito Desio", \\ Università degli Studi Milano, via Mangiagalli, Milan, Italy \\ ${ }^{5}$ Department of Earth Sciences, University College London, Gower Street, London, WC1E 6BT, UK \\ ${ }^{6}$ Bremen University, Fachbereich 5 - Geowissenschaften, Postfach 330440, 28334 Bremen \\ Germany \\ ${ }^{7}$ Department of Geological Sciences, Stockholm University, SE-106 91 Stockholm, Sweden \\ ${ }^{8}$ School of Earth and Ocean Sciences, Cardiff University, Cardiff, CF10 3AT, UK \\ ${ }^{9}$ Tanzania Petroleum Development Corporation, PO Box 2774, Dar es Salaam, Tanzania \\ ${ }^{10}$ RPS Energy, Goldvale House, 27-42 Church Street West, Woking, Surrey, GU21 6DH, UK \\ ${ }^{11}$ Department of Earth Sciences, University of Oxford, South Parks Road., Oxford, OX1 3AN, UK
}

\begin{abstract}
The 2009 Tanzania Drilling Project (TDP) expedition to southeastern Tanzania cored a total of $572.3 \mathrm{~m}$ of sediments at six new mid-Cretaceous to mid-Paleocene boreholes (TDP Sites 36, 37, 38, 39, 40A, 40B). Added to the sites drilled in 2007 and 2008, the new boreholes confirm the common excellent preservation of planktonic and benthic foraminifera and calcareous nannofossils from core samples that will be used for biostratigraphy, evolutionary studies, paleoceanography and climatic reconstructions from the Tanzanian margin, with implications elsewhere. The new sites verify the presence of a relatively expanded Upper Cretaceous succession in the region that has allowed a new stratigraphic unit, named here as the Lindi Formation (Fm), to be formally defined. The Lindi Fm (upper Albian to Coniacian), extending $\sim 120 \mathrm{~km}$ between Kilwa and Lindi, comprises a 335-m-thick, outer-shelf to upper-slope unit, consisting of dark gray claystone and siltstone interbeds, common finely-laminated intervals, minor $\mathrm{cm}$-thick sandstones and up to $2.6 \%$ organic carbon in the Turonian. A subsurface, composite stratotype section is proposed for the Lindi Fm, with a gradational top boundary with the overlying Nangurukuru Fm (Santonian to Maastrichtian) and a sharp bottom contact with underlying upper Albian sandstones.

The section cored at TDP Sites 36 and 38 belongs to the Lindi Fm and are of lower to middle Turonian age (planktonic foraminifera Whiteinella archaeocretacea to Helvetoglobotruncana helvetica Zones and nannofossils subzones UC6b \pm UC7). The lower portion of TDP Site 39 (uppermost part of the Lindi Fm) is assigned to the lower to upper Coniacian (planktonic foraminifera Dicarinella concavata Zone and nannofossils zone UC 10), while the remaining part of this site is attributed to the Coniacian-Santonian transition and younger Santonian (planktonic foraminifera $D$. asymetrica Zone and upper part of nannofossils zone UC10). TDP Site 37 recovered relatively expanded (150 m thick), monotonous calcareous claystones from the lower to upper Maastrichtian (planktonic foraminifera Pseudoguembelina palpebra to Abathomphalus mayaroensis Zones and nannofossils zones UC19 to $\mathrm{UC} 20 \mathrm{a}^{\mathrm{TP}}$ ) that were separated by a hiatus and/or a faulted contact from overlying brecciated carbonates of the Selandian (middle Paleocene: PF Zone P3 and nannofossil zone NP5). The lower portion of TDP Sites 40A and 40B recovered sandstones and conglomerates barren of microfossils. Their overlying parts were assigned to incomplete sections of the nannofossil zones NC6A to NC8 (uppermost Barremian to lower Albian). Benthic foraminiferal assemblages allowed the Barremian to lower Aptian to be identified in TDP Sites 40A and 40B, while the upper Aptian to middle Albian (Hedbergella trocoidea to Ticinella primula Zones) were assigned using planktonic foraminifera. Cores recovered at TDP 39 (Coniacian-Santonian) and at TDP Sites 40A and 40B (Barremian-middle Albian) represent the first time that these two intervals have been continuously cored and publicly documented in Tanzania.
\end{abstract}


Bulk sediment isotope records generated for the new sites show lower $\delta^{18} \mathrm{O}_{\text {carb }}$ values in the Turonian and Santonian ( $\sim-3.5 \%$ to $-5 \%$ ) than in the Maastrichtian ( $-3 \%$ ), a situation consistent with extreme global warmth in the older intervals and cooling toward the end of the Cretaceous. Also, similar to Turonian sites from previous TDP expeditions, a negative $\delta^{13} \mathrm{C}_{\text {org }}$ excursion was detected across the $W$. archaeocretacea-H. helvetica boundary of TDP Site 36 (close to, but above, the Cenomanian-Turonian boundary). This excursion probably responded to local processes in the region, but it is unknown whether they were related to the recovery phase from Ocean Anoxic Event 2.

Keywords: Mandawa and Ruvuma basins, Lindi Formation, Upper Cretaceous biostratigraphy, glassy foraminifera, pristine calcareous nannofossils, Cretaceous-Paleogene boundary.

\section{Introduction}

A major challenge in studying ancient climates using geochemical proxies from marine microfossils is finding calcareous shells with good enough preservation that original geochemical ratios survive. Since 2002, a major focus of the Tanzania Drilling Project (TDP) has been to study Late Cretaceous-Neogene climates using outcrop and cored sediment samples from southeastern Tanzania (Fig. 1), a well-known province for the occurrence of calcareous microfossils with excellent preservation (Pearson et al., 2001, 2004, 2006, 2007; Bown, 2005a; Lees, 2007; Bown et al., 2008; Jiménez Berrocoso et al., 2010, 2012; Falzoni and Petrizzo, 2011; Petrizzo et al., 2011; Wendler et al., 2011, 2013; Falzoni et al., 2013; MacLeod et al., 2013; Wendler and Bown, 2013; Huber and Petrizzo, 2014; Haynes et al., in press; Lees and Bown, in review). The excellent preservation of microfossils has been attributed to shallow burial of sediments that are clay rich and relatively impermeable (e.g., Pearson et al., 2004, 2006; Nicholas et al., 2006, 2007). This situation makes these microfossils invaluable geochemical and biostratigraphic archives of the tropical-subtropical, fully open marine conditions in which their calcareous shells formed (Pearson et al., 2004, 2006; Nicholas et al., 2006; Jiménez Berrocoso et al., 2010, 2012). Furthermore, the fact that (1) oil seeps have been found in Paleogene outcrops near Kilwa (Pearson et al., 2004, 2006; Nicholas et al., 2006), and (2) up to $2.6 \%$ organic carbon content has been recorded in Turonian cores near Lindi (Jiménez Berrocoso et al., 2012) make investigations into TDP sediments valuable for understanding the petroleum geology of the region. In this contribution, we address the six boreholes (TDP Sites 36, 37, 38, 39, 40A and 40B) that were drilled during the 2009 TDP field season and formally propose a new stratigraphic unit spanning a large part of the Late Cretaceous in southeastern Tanzania.

A first phase of TDP activities, spanning 1998 to 2006, centered on litho- and biostratigraphy, structural geology and refined organic and inorganic geochemistry of Cenozoic samples, but included some Upper Cretaceous intervals (Pearson et al., 2004, 2006, 2008; Stewart et al., 2004; Bown, 2005a; Bown and Dunkley Jones, 2006; Nicholas et al., 2006, 2007; van Dongen et al., 2006; Lees, 2007; Bown et al., 2008; Handley et al., 2008, 2012; Wade and Pearson, 2008; Bown and Pearson, 2009; Cotton and Pearson, 2011). The second phase began in 2007 and focused on Upper Cretaceous sediments. Samples recovered demonstrated the presence of a more expanded and complete Upper Cretaceous succession (Jiménez Berrocoso et al., 2010, 2012) than suggested by results of the first TDP phase. In addition to a composite Albian-Campanian section, that is at least $350 \mathrm{~m}$ thick, the sediments drilled in 2007 and 2008 provided (1) new insights into the stratigraphy and depositional history of the Tanzanian margin (Jiménez Berrocoso et al., 2010, 2012), (2) planktonic and benthic foraminifera, calcareous nannofossils and calcareous dinoflagellates with excellent preservation that helped constrain Tanzanian biostratigraphy, species taxonomy and paleoecology (Jiménez Berrocoso et al., 2010, 2012; Petrizzo et al., 2011; Falzoni and Petrizzo, 2011; Falzoni et al., 2013; Wendler et al., 2011, 2013; Huber and Petrizzo, 2014; Haynes et al., in press; Lees and Bown, in review), (3) bulk rock geochemistry that included isotopic evidence for both partial recovery of Ocean Anoxic Event 2 (OAE2) -close to the Cenomanian-Turonian (C-T) boundary- and climatic cooling from the Turonian into the Campanian (Jiménez Berrocoso et al., 2010, 2012), and (4) foraminiferal isotopic evidence for a stable and hot Turonian (MacLeod et al., 2013) challenging hypotheses of greenhouse glacial episodes.

The 2009 TDP expedition produced more than $500 \mathrm{~m}$ of core from discrete intervals of the Aptian-Albian (TDP Sites 40A and 40B), Turonian (TDP Sites 36 and 38), Coniacian-Santonian (TDP Site 39), and MaastrichtianPaleocene (TDP Site 37) from sites in the vicinity of Kilwa and Lindi (Figs. 1). Here, we present a detailed synthesis 
of the litho-, bio- and chemostratigraphy of the new sites. Combined with sediments cored in 2007 and 2008, samples from the last TDP season yield exquisitely preserved microfossils in most of the intervals and reveal a nearly biostratigraphically complete Upper Cretaceous section of at least $540 \mathrm{~m}$ in composite thickness. We formally define a new unit (the Lindi Formation [Fm]) that extends the lower limit of the Kilwa Group (Nicholas et al., 2006) from the Santonian to at least the upper Albian. Together, the 2007 to 2009 TDP sediments represent an unprecedented sample set that helps constrain (1) the depositional settings, stratigraphy and biostratigraphy of the Tanzanian margin, (2) the biodiversity and paleoceanography of the subtropical-tropical Indian Ocean, and (3) the temperature and climate history of the Late Cretaceous.

\section{Geological setting}

The studied sediments belong to the Mandawa and Rovuma basins of southern Tanzania and northern Mozambique (Salman and Abdula, 1995) (Fig. 1). Descriptions of the regional geology and tectonic evolution of these basins can be found in Balduzzi et al. (1992), Salman and Abdula (1995), Veeken and Titov (1996), Mpanda (1997), Kapilima (2003), Kejato (2003), Pearson et al. (2004), Nicholas et al. (2006, 2007) and Key et al. (2008). We focus on the mid- to Upper Cretaceous marine succession of southeastern Tanzania (Figs 2, 3). Upper Cretaceous surface exposures, albeit of variable quality, occur between Kilwa and Lindi (Moore et al., 1963; Kent et al., 1971; Gierlowski-Kordesch and Ernst, 1987; Ernst and Schlüter, 1989; Ernst and Zander, 1993; Pearson et al., 2004, 2006; Nicholas et al., 2006; Jiménez Berrocoso et al., 2010, 2012) (Fig. 1). The succession consists of mudstones and minor intercalations of sandstones that strike approximately parallel to the coastline and have a shallow oceanward dip (Nicholas et al., 2007). A stratigraphic division of the Upper Cretaceous of this area was proposed by Nicholas et al. (2006), who assigned the Santonian-Maastrichtian sediments to the Nangurukuru Fm (Figs 2,3). The underlying post-Albian to pre-Santonian interval was attributed to a separate unit, with one or more disconformities above the Aptian-Albian Kihuluhulu and Kingongo Marls (Balduzzi et al., 1992; Veeken and Titov, 1996; Nicholas et al., 2006). The litho- and biostratigraphy gathered from the 2007 to 2009 TDP seasons, however, allow this post-Albian to pre-Santonian unit to be proposed as the Lindi Fm in southeastern Tanzania (see below). Figure 2 compares the stratigraphic divisions proposed herein, including the Lindi Fm, to previous stratigraphic divisions of the Mandawa and Ruvuma basins (e.g., Mpanda, 1997; Kapilima, 2003; Kejato, 2003; Nicholas et al., 2006; Thomas, 2007; Key et al., 2008). The stratigraphic extent of the TDP sites drilled in 2007-2009 is displayed in Figure 3.

\section{Methods}

A portable rig with wireline capability and a maximum penetration depth of $\sim 200 \mathrm{~m}$ was used by the Tanzania State Mining Corporation (STAMICO) to drill the 2007-2009 TDP sites. Continuous coring was carried out using diamond bits with HQ and NQ coring assemblies that provided, respectively, core diameters of $48 \mathrm{~mm}$ and $64 \mathrm{~mm}$ (only TDP Site 37). Sample preparation methods are described in detail in Jiménez Berrocoso et al. (2010, 2012). The planktonic foraminiferal biozonation scheme employed here is based on integration of the standard Cretaceous tropical/subtropical schemes of Robaszynski and Caron (1995 - Mediterranean), Sliter (1989 - eastern Pacific), Huber et al. (2008 - western Atlantic), Huber and Leckie (2011 - global), and Petrizzo et al. (2011 southeastern Tanzania). For the Paleocene, the planktonic foraminiferal biozonation scheme of Berggren et al. (1995) was used. Absolute ages assigned to the biozones and secondary datum events and their reference sources are shown in Table 1. The NC nannofossil biozones of Roth (1978), with the modifications/subzones of Bralower et al. (1993), were used for the Aptian-Albian. The UC nannofossil biozones of Burnett et al. (1998) were used for the Upper Cretaceous. For the Paleocene, the nannofossil biozones of Martini (1971) were used.

TDP Sites 36 to 39 . The $\delta^{13} \mathrm{C}_{\text {carb }}$ and $\delta^{18} \mathrm{O}_{\text {carb }}$ of bulk carbonate samples were measured at a resolution of $\sim 1$ sample/core. The $\% \mathrm{CaCO}_{3}, \% \mathrm{C}_{\text {org }}$ and $\delta^{13} \mathrm{C}_{\text {org }}$ (carbon isotopic ratio of bulk organic matter) were measured on about half of these samples (that is, at an average resolution of $\sim 1$ sample every other core). Detailed descriptions of the methodology used for the chemostratigraphy of these sites can be found in Jiménez Berrocoso et al. $(2010,2012)$. 
TDP Site $40 B$. The $\delta^{13} \mathrm{C}_{\text {carb }}$ and $\delta^{18} \mathrm{O}_{\text {carb }}$ of bulk carbonate samples were measured at a resolution of $\sim 2-8$ samples/core. Powdered samples were first roasted in a vacuum oven for 1 hour at $200^{\circ} \mathrm{C}$ to drive off residual water and volatiles. All samples were analysed by continuous-flow mass spectrometry using a Gasbench connected to a ThermoFinnegan DeltaPlus XP mass spectrometer. All isotope data were measured in the Bloomsbury Environmental Isotope Facility at University College London and are reported in \%o deviation from Vienna Peedee belemnite (VPDB). One standard deviation error on internal standards was better than $\pm 0.1 \%$ for both $\delta^{13} \mathrm{C}$ and $\delta^{18} \mathrm{O}$ during analysis of the samples.

The $\delta^{13} \mathrm{C}_{\text {org }}$ data of TDP Site 40B, measured at a resolution of $\sim 3-8$ sample/core, were obtained from $\sim 1$ $\mathrm{cm}^{3}$ of powdered samples that were reacted with $\sim 10 \% \mathrm{HCl}$ until decarbonation was complete. Samples were then repeatedly rinsed with deionized water, centrifuged and the supernatant removed until neutrality was reached. Samples were then oven dried at $\sim 50^{\circ} \mathrm{C}$ and then re-powdered by hand with an agate pestle and mortar, before being weighed ( $\sim 10$ to $40 \mathrm{mg}$ ) into tin capsules and sealed. Samples were analyzed by continuous-flow mass spectrometry using a Flash EA connected to a ThermoFinnegan Delta V mass spectrometer. All isotope data were measured in the Bloomsbury Environmental Isotope Facility at University College London and are reported in \%o deviation from Vienna Peedee belemnite (VPDB). One standard deviation error on internal standards was better than $\pm 0.2 \%$ for $\delta^{13} \mathrm{C}$.

Samples for total organic carbon (\%TOC) of TDP Site 40B were weighed ( $60-100 \mathrm{mg}$ ) and decarbonated with $\sim 10 \% \mathrm{HCl}$ in silver foil cups. Once decarbonation was complete, samples were left to dry on a hotplate at $\sim 50^{\circ} \mathrm{C}$. Samples for Total Carbon (\%TC) were weighed ( 10 to $\left.30 \mathrm{mg}\right)$ in tin cups. All samples were analysed by combustion in a ThermoFinnegan Flash EA. Reproducibility of an internal standard was better than $0.1 \mathrm{wt} \%$. The $\% \mathrm{CaCO}_{3}$ estimates were calculated by subtracting \% TOC from \% $\mathrm{TC}$ to yield \% $\mathrm{TIC}$ and, then, multiplying this value by 8.3 , following the assumption that all inorganic carbon is present as $\mathrm{CaCO}_{3}$.

\section{Results}

\subsection{TDP Site 36}

TDP Site 36 was drilled $0.5 \mathrm{~km}$ west of the main road, $8.7 \mathrm{~km}$ southwest of Lindi (UTM 37L 569784, 8891353) (Fig. 4). The site was positioned $134 \mathrm{~m}$ northwest of the lower-middle Turonian TDP Site 34 (Jiménez Berrocoso et al., 2012), near a sandy soil facies that was predicted to be Cenomanian, based on field mapping. The main goal was to recover the C-T boundary interval. TDP Site 36 was drilled to $110.5 \mathrm{~m}$, with good recovery from the surface to $102 \mathrm{~m}$, and moderate recovery from $102 \mathrm{~m}$ to the bottom of the hole. Drilling was stopped in sandstones barren of microfossils below a thick section of Turonian mudstones. No Cenomanian sediments were recovered.

\subsubsection{Lithostratigraphy and bulk sediment composition}

Underlying an interval with sandy soil and heavily weathered rocks (cores TDP36/1-3), the main lithologies from 9 to $102 \mathrm{~m}$ are $\mathrm{mm}$ - to $\mathrm{cm}$-thick, interbedded, medium to dark olive gray, sandy siltstones and claystones (Figs 5a, 6a), with common occurrences of finely-laminated intervals. Cores TDP36/15, 20-25, 27, 30, 38 and 39 exhibit $\mathrm{mm}$ - to $\mathrm{cm}$-thick layers of light to medium gray, massive, lithified siltstones, with sharp to gradational top and bottom contacts (Fig. 6b). Light gray, thin sandstone partings are observed in cores TDP36/21, 23, 39 and 41. Yellowish brown, $\mathrm{mm}$ - to $\mathrm{cm}$-sized nodules and sub-horizontal and cross-cutting carbonate veins are sporadically present in this interval. Bioclastic debris, including inoceramids and ammonites, is relatively common, and mottling attributed to bioturbation is rare (Fig. 5a). Soft-sediment deformation (slightly inclined laminations) is common (Fig. 6c). Lamination appears highly disturbed in parts of cores TDP36/13, 33-35 and 39 (Fig. 6d). At 102 $\mathrm{m}$, a sharp, undulating contact is observed between the overlying dark gray mudstones and an interval with light greenish gray, up to medium-grained, cemented sandstones (Fig. 6e). These sandstones, extending from $102 \mathrm{~m}$ to the bottom of the hole, generally show massive texture and can include mm-sized, greenish gray mud-clasts (Fig. 6f). Core TDP36/46 exhibits a loaded surface between a light gray sandstone bed overlying a greenish gray siltstone interval (Fig. 6f). 
The $\% \mathrm{CaCO}_{3}$ and $\% \mathrm{C}_{\text {org }}$ range from $2 \%$ to $30 \%$ (average $=11.8 \% \pm 4.9 \%, 1$ s.d.) and from $0.1 \%$ up to $2.3 \%$ (average $=1.1 \% \pm 0.4 \%, 1$ s.d.), respectively. The two metrics vary inversely throughout the majority of the sampled core, and there are no obvious trends through the section (Fig. 5a).

\subsubsection{Foraminiferal biostratigraphy}

Samples collected from 0-7.4 $\mathrm{m}$ and from 97.76-110.5 m are barren of foraminifera, whereas samples from 7.4-97.76 m (cores TDP36/2-41) provide rare to abundant foraminifera. Specimens with translucent, empty shells are relatively rare. Instead, most shells show infilling with calcite or pyrite and some degree of test recrystallization. Planktonic foraminifera indicate the middle Turonian Helvetoglobotruncana helvetica Zone from 7.4-93.01 m (cores TDP36/2-40) (Fig. 5a, Table 1), based on the presence of the nominate taxon. The underlying interval (from 93.01$97.76 \mathrm{~m}$; cores TDP36/40-41) is assigned to the lower Turonian Whiteinella archaeocretacea Zone (Fig. 5; Table 1), based on the absence of $H$. helvetica, Globigerinelloides bentonensis and Rotalipora spp. and the presence of $W$. archaeocretacea, W. aprica, W. brittonensis, H. praehelvetica, Dicarinella hagni and D. elata.

Benthic foraminifera range from $20-40 \%$ of the total foraminiferal assemblage and are similar in taxonomic composition to the lower-middle Turonian assemblage of TDP Site 31 (Jiménez Berrocoso et al., 2012), which was located $0.9 \mathrm{~km}$ east of TDP Site 36 (Fig. 4). The species composition and planktonic/benthic ratio of TDP Site 36 are consistent with interpretations of an outer shelf-upper slope setting during the early-middle Turonian, as was inferred from other TDP sites spanning the same time interval (Jiménez Berrocoso et al., 2010, 2012; Wendler et al., 2011, 2013).

\subsubsection{Calcareous nannofossil biostratigraphy}

Samples were examined from between $5.03 \mathrm{~m}$ (core TDP36/2) to the base of the hole (core TDP36/47). Samples from $98 \mathrm{~m}$ down were barren, or virtually so, of nannofossils. The rest of the section contains generally moderate to excellently-preserved assemblages, with very low to low abundance characterizing the lower part of the section and with low to moderate abundance from around $20 \mathrm{~m}$ and up. The entire section falls into nannofossil subzone UC6b (Fig. 5a), based on the presence of Eprolithus moratus. An extended UC6b, representing the lower Turonian, has been noted in several other TDP sites (21, 22, 24, 24B, 26, 34, 38: see Jiménez Berrocoso et al. 2010, 2012 and below). The section may or may not include UC7, due to the seeming rarity of the marker datum, base Quadrum gartneri, from Tanzania in general. Insight into this biostratigraphic interval is the subject of a separate, high-resolution study of a composite TDP Upper Cretaceous section.

\subsubsection{Chemostratigraphy}

The $\delta^{13} \mathrm{C}_{\text {carb }}$ and $\delta^{18} \mathrm{O}_{\text {carb }}$ values range from $-11.9 \%$ to $1.7 \%$ (average $=-1.7 \%$. $\pm 2.7 \%$, 1 s.d.) and from $12.9 \%$ to $-1.5 \%$ (average $=-3.9 \%$ o $\pm 1.5 \%$, 1 s.d.), respectively (Fig. $5 \mathrm{a}$ ). Except for a few point excursions, likely of diagenetic origin, the $\delta^{13} \mathrm{C}_{\text {carb }}$ plot shows no particular long-term trends along the recovered interval. A gradual decrease from $-3.0 \%$ to $-4.0 \%$ is observed in the $\delta^{18} \mathrm{O}_{\text {carb }}$ profile from $85 \mathrm{~m}$ up to $\sim 10 \mathrm{~m}$. The $\delta^{13} \mathrm{C}_{\text {org }}$ values range from $-24.2 \%$ to $-21.3 \%$ (average $=-22.6 \% \pm \pm 0.7 \%, 1$ s.d.). A notable feature of this profile is the existence of a $\sim 2 \%$ decrease across the Whiteinella archaeocretacea-Helvetoglobotruncana helvetica boundary (cores TDP36/4138; Fig. 5a), which similar to that documented in TDP Sites 30 and 34 near the same zonal boundary (Jiménez Berrocoso et al., 2012).

\subsection{TDP Site 37}

TDP Site 37 was located on top of Kimamba Hill, 19.7 km west of Kilwa Masoko (UTM 37L 536532, 9013949) (Fig. 7). This site was drilled in an attempt to recover a complete Cretaceous-Paleogene (K-Pg) boundary interval, encouraged by the fact that middle Paleocene sediments were recovered between 10 and $14 \mathrm{~m}$ below the surface of TDP Site 27 (Jiménez Berrocoso et al., 2012), only $400 \mathrm{~m}$ southeast of TDP Site 37 (Fig. 7). The 2007 attempt was aborted because of hole instability caused by unconsolidated sandstones immediately below the oldest marine Paleocene sediments drilled. For the 2009 redrill, it was hoped that casing the hole and using a larger diameter drill-pipe would address hole stability. This approach succeeded in achieving excellent core recovery to a 
depth of $172.1 \mathrm{~m}$ before drilling was stopped in lower Maastrichtian mudstones. Unfortunately, no continuous K-Pg boundary interval was present. Instead, an interval of breccias was found that separated middle Paleocene marine carbonates from a thick section of Maastrichtian mudstones.

\subsubsection{Lithostratigraphy and bulk sediment composition}

Similar to TDP Site 27 (Jiménez Berrocoso et al., 2012), the upper part of TDP Site 37 (from 2 to $16 \mathrm{~m}$; cores TDP37/2-10) exhibits a middle Paleocene (see Section 4.2.2) interval with grayish orange to light yellow limestones that show common bioclasts and, generally, mm-scale, vuggy porosity (Figs 8a, 9a). While this porosity seems to decrease below core TDP37/7, the limestones are intensely brecciated between cores TDP37/5-10 (Figs 8a, 9b). Thin-sections from cores TDP37/2, 4 and 6 reveal packstone textures with common benthic bioclasts (e.g., corals, red algae, benthic foraminifera) that, together, indicate reworking of shallow-water carbonates.

A remarkable change in lithology occurs in core TDP37/11 (Figs 8a, 9c-d). A brecciated interval from 17 to $21.25 \mathrm{~m}$ (cores TDP37/11-12) shows cm-sized angular to sub-rounded, poorly-sorted carbonate clasts in a dark gray sandy siltstone matrix (Figs. 8a, 9c-d). A washed-residue sample from this matrix at $18 \mathrm{~m}$ (core TDP37/11; Figs 8a, 9c) reveals a mixed planktonic foraminiferal assemblage, with middle Paleocene and Maastrichtian specimens (see Section 4.2.2), along with abundant detrital quartz. Below the breccias, cores TDP37/12-69 contain thick lower to upper Maastrichtian mudstones (Figs 8a, b, 9e, f). The origin of these breccias could be related to the tectonic evolution of this part of the basin. TDP Site 37 was drilled on top of Kimamba Hill (Fig. 7), a fault-bounded topographic high, interpreted as the surface expression of a deeper-seated flower structure (Nicholas et al., 2007). One possibility is that tectonic uplift of Kimamba Hill could produce erosion of Maastrichtian to middle Paleocene sediments and their deposition (i.e., breccias of cores TDP37/11-12) with mixed Maastrichtian and Paleocene foraminifera (Figs 8a, 9c, d). A hiatus of $\sim 7.6 \mathrm{Myr}$ would exist between the upper Maastrichtian mudstones of cores TDP37/12-17 and the overlying breccias of cores TDP37/11-12 (Fig. 8a). This sedimentary breccia would have been deposited before the end of the middle Paleocene, based on the middle Paleocene age of the overlying limestones (cores TDP37/2-10; Figs 8a, 9a, b). An alternative scenario is that cores TDP37/11-12 represented tectonic breccias. TDP Site 37 would have crossed a localized zone of brittle deformation (i.e., a fault zone) that incorporated carbonate fragments within a sandy siltstone matrix. Because of this fragmentation, infiltration by groundwater and precipitation of secondary minerals (e.g., calcite) would be expected in the fault zone. No such minerals, however, have been detected in the breccias or in the overlying and underlying sediments, a situation that challenges this scenario. Yet, because only one site at Kimamba Hill (i.e., TDP Site 37) found these breccias and drilled into Upper Cretaceous sediments, we cannot totally discard this explanation. Regardless of a sedimentary, tectonic or a combined origin for these breccias, whether a complete K-Pg boundary interval was ever deposited at Kimamba Hill is unknown. If deposited, however, its preservation is difficult to reconcile with the interpretation of erosion and/or tectonism mentioned above.

From $21.35 \mathrm{~m}$ to the bottom of the hole, the Maastrichtian succession is represented by medium to dark olive gray, mostly massive, monotonous, calcareous claystones, with rare to common bioturbation mottling (Figs 8a, $\mathrm{b}, 9 \mathrm{e}, \mathrm{f}$ ). These sediments appear weakly-bedded, with slightly inclined lamination, from 154 to $168 \mathrm{~m}$ (cores TDP37/62-67). Pyrite nodules and bioclastic debris occur in some intervals.

The $\% \mathrm{CaCO}_{3}$ is relatively high at this site, with values ranging from $22.5 \%$ to $84.6 \%$ (average $=38.2 \% \pm$ $13.6 \%, 1$ s.d.; Fig. $8 \mathrm{a}, \mathrm{b}$ ). The $\% \mathrm{C}_{\text {org }}$ is generally low and constant, with values between $0.2 \%$ and $0.4 \%$ (average $=$ $0.2 \% \pm 0.0 \%, 1$ s.d.; Fig. $8 \mathrm{a}, \mathrm{b}$ ). Whereas no $\% \mathrm{C}_{\text {org }}$ data were obtained from the middle Paleocene limestones, large $\% \mathrm{CaCO}_{3}$ variations are observed in the samples of this interval (Fig. 8a).

\subsubsection{Foraminiferal biostratigraphy}

Paleocene assemblages. Sieved, sand-sized $(>63 \mu \mathrm{m})$ sediment residues collected from the matrix of the brecciated limestones of cores TDP37/2 and 6 yielded foraminiferal assemblages similar to those described in TDP Site 27 (Jiménez Berrocoso et al., 2012), with rare planktonic and more common benthic taxa. Foraminiferal preservation is poor in these samples. Benthic species include Nuttalloides truempyi and possible Osangularia sp., Globorotalites sp., Cibicidoides sp., Stilostomella sp., Coryphostoma sp., Neoflabellina sp. and Gyroidinoides sp. 
The planktonic species found (Morozovella angulata, M. velascoensis, M. pasionensis, M. apanthesma, M. occlusa, Subbotina cancellata, S. triangularis, S. triloculinoides, Parasubbotina varianta and Globanomalina chapmani) suggest that cores TDP37/2 and 6 belong to the middle-upper Paleocene (Fig. 8a). The presence of Morozovella angulata together with M. velascoensis, M. pasionensis and G. chapmani in the absence of G. pseudomenardii is suggestive of the Zone P3. The complete absence of species of Igorina in TDP37, in particular I. pusilla and I. alberi that are important in the definition of Subzones P3a and P3b (Berggren and Pearson, 2005; Wade et al., 20011), prevents a more precise zonal assignment. Unconsolidated matrix material from the breccia of core TDP37/11 yielded a mixed foraminiferal assemblage with middle Paleocene (M. angulata and M. conicotruncata) and Maastrichtian (Racemiguembelina fructicosa, Planoglobulina multicamerata and several globotruncanids) species (Fig. 8a). This foraminiferal assemblage must be reworked, indicating erosion of at least Upper Cretaceous outer-shelf sediments (see also Section 4.2.1). The micropaleontology of the limestone clasts from TDP Site 37 has not been studied. We predict, however, they are of middle Paleocene age (Fig. 8a), by lithological analogy with the in situ limestones and limestone clasts from TDP Site 27 (Jiménez Berrocoso et al., 2012).

Upper Cretaceous assemblages. The samples analysed from the lower part of core TDP37/12 to the bottom of the borehole yielded assemblages with abundant planktonic foraminifera representing $60-85 \%$ of the specimens in most samples. Calcareous benthic species are rare, while agglutinated forms are rare to common. Preservation is good in planktonic and benthic specimens, but most shells show calcite infilling and no glassy texture. The upper Maastrichtian Abathomphalus mayaroensis Zone is assigned to the interval 21.69-28.88 m (Fig. 8a, Table 1) based on the presence of the nominate taxon together with A. intermedius, Contusotruncana contusa, Pseudotextularia elegans, Globotruncana aegyptica, and Racemiguembelina fructicosa. The uppermost Maastrichtian is judged to be missing, due to the absence of Plummerita hantkeninoides and Pseudoguembelina hariaensis. The middle Maastrichtian R. fructicosa Zone is identified from 28.88 to $84.90 \mathrm{~m}$ (Fig. 8a; Table 1) based on the consistent occurrence of the nominate taxon and the absence of A. mayaroensis. The lower Maastrichtian Pseudoguembelina palpebra Zone is attributed to the interval $84.90 \mathrm{~m}$ to the bottom of the hole (Fig. 8a, b, Table 1) according to the presence of the nominate taxon along with Gansserina gansseri and the absence of R. fructicosa.

Ages for the foraminiferal datums listed in Table 1 have been used to create an age model for TDP Site 37. Results indicate that the interpreted hiatus and/or faulted contact between the upper Maastrichtian A. mayaroensis Zone and the middle Paleocene (zone P3b-P4) represent at least $~ 7.6 \mathrm{Myr}$. The sedimentation rate through the lower-upper Maastrichtian was relatively high, ranging from 62.8-103.5 m/Myr.

\subsubsection{Calcareous nannofossil biostratigraphy}

Paleocene assemblages. Thirteen samples were studied of which two were barren (cores TDP37/1 and 4) and three contained only very sparse assemblages (cores TDP37/2 and 3). Cores TDP37/6 through 11 generally yielded nannofossils that are common to abundant and exceptionally well preserved. The assemblages are diverse and attain species richness values (up to 56 species) that are higher than typically observed (Bown et al., 2004). The high quality of preservation is evident from the presence of abundant small coccoliths (Prinsius and Toweius) and conspicuous fragile taxa (holococcoliths and Calciosolenia). The assemblages are dominated by abundant to common Prinsius, Toweius, Coccolithus, Neochiastozygus, Ericsonia, Umbilicosphaera jordanii and Zeugrhabdotus sigmoides. Ellipsolithus coccoliths are also frequent and diverse. The presence of Pontosphaera spp. is notable because the family and genus has only been found in rocks of this age in the previously reported TDP Site 27 (Jiménez Berrocoso et al., 2012). Most samples also contained rare reworked, long-ranging nannofossils of mid- to Late Cretaceous age (e.g., Micula, Eiffellithus, Watznaueria and Retecapsa).

In cores TDP37/11 through 6, the presence of Ellipsolithus macellus and Fasciculithus pileatus, and the absence of Heliolithus kleinpelli or discoasters indicate an age equivalent to nannofossil zones NP4-5 (Selandian, middle Paleocene; Fig. 8a). The presence of several questionable specimens attributable to Fasciculithus tympaniformis suggests a position close to the NP4/5 zonal boundary. This age determination is supported by the presence of Sphenolithus, Toweius eminens, Neochiastozygus perfectus and Fasciculithus spp. typical of the 
Selandian radiation (e.g., Varol, 1998; Bernaola et al., 2009). These assemblages are similar to those recovered from the Paleocene interval at TDP Site 27 (Jiménez Berrocoso et al., 2012).

Upper Cretaceous assemblages. Samples were examined from between $19.25 \mathrm{~m}$ (core TDP37/11) to the base of the hole $(\sim 172 \mathrm{~m}$, core TDP37/69). All samples were productive, with moderate to excellent preservation throughout and moderate to high overall abundance. The lower part of the section (below $119.50 \mathrm{~m}$ ) falls into UC19 (between top Reinhardtites levis and base Lithraphidites quadratus), which is suggested as lower Maastrichtian. Above this, and to the top of the section, $\mathrm{UC}_{20} \mathrm{a}^{\mathrm{TP}}$ is indicated, based on base L. quadratus at $119.50 \mathrm{~m}$. This suggests the upper Maastrichtian (see Pérez Rodríguez et al., 2012 for a discussion on candidates to define this substage boundary). The uppermost Maastrichtian is missing: Micula murus and M. prinsii are both absent. This is the first TDP borehole to drill such an extended and young Maastrichtian sequence in Tanzania.

\subsubsection{Chemostratigraphy}

The $\delta^{13} \mathrm{C}_{\text {carb }}$ and $\delta^{18} \mathrm{O}_{\text {carb }}$ values at this site are remarkably constant with few point excursions (Fig. 8a, b). The $\delta^{13} \mathrm{C}_{\text {carb }}$ values fall largely between $1.0 \%$ and $2.0 \%$ and the $\delta^{18} \mathrm{O}_{\text {carb }}$ values between -4.0 and $-3.0 \%$, but the total ranges of the $\delta^{13} \mathrm{C}_{\text {carb }}$ and $\delta^{18} \mathrm{O}_{\text {carb }}$ values are $-6 \%$ to $2.1 \%$ (average $=1.2 \% \pm 1.1 \%$, 1 s.d.) and $-7.2 \%$ to $-2.5 \%$ o (average $=-3.5 \% \pm \pm 0.6 \%, 1$ s.d.), respectively (Fig. 8a, b). There is a gradual increase in $\delta^{13} \mathrm{C}_{\text {carb }}$ from $1.0 \%$ at the bottom up to $2.0 \%$ at the top of the Maastrichtian. Over the same interval, the $\delta^{18} \mathrm{O}_{\text {carb }}$ values generally increase by $\sim 1.0 \%$. The $\delta^{13} \mathrm{C}_{\text {org }}$ values range from $-26.1 \%$ to $-23.3 \%$ (average $=-25.5 \% \pm 0.5 \%$, 1 s.d.; Fig. $8 \mathrm{a}$, b), but most values fall between $-25 \%$ and $-26 \%$ and show the same gradually increasing values observed in the $\delta^{18} \mathrm{O}_{\text {carb }}$ and $\delta^{13} \mathrm{C}_{\text {carb }}$.

\subsection{TDP Site 38}

TDP Site 38 was positioned $9.4 \mathrm{~km}$ west of the Nangurukuru junction, $30.5 \mathrm{~km}$ northwest of Kilwa Masoko (UTM 37L 528972, 9026659) (Fig. 7). The site was drilled $500 \mathrm{~m}$ northeast of a surface sample assigned to the upper part of the planktonic foraminiferal Helvetoglobotruncana helvetica Zone (middle Turonian) and $1.7 \mathrm{~km}$ southwest of a surface sample that was assumed to be Cenomanian, based on field mapping of the area. The main goal for this site was to try to recover the C-T boundary interval. The site was drilled to $30 \mathrm{~m}$, with good to moderate recovery from the surface to the bottom of the hole. Drilling was terminated in Turonian sediments once it was recognized that the C-T boundary would not be within reach of the drill-string.

\subsubsection{Lithostratigraphy and bulk sediment composition}

Below $90 \mathrm{~cm}$ of modern soil, the main lithologies are dark gray to olive black, massive to weakly bedded claystones (Figs 10, 11a, b), with sporadic occurrences of cm-thick sandstone partings in cores TDP38/5 and 7. Evidence of modern weathering on these sediments, such as high friability and oxide stains along fractures (Figs 10, 11a), are frequent from the surface of the hole to the bottom of core TDP38/7. Calcite veins filling fractures were observed in cores TDP38/5 and 8 (Fig. 11a). No macrofossil debris or bioturbation are visible in these cores.

The $\% \mathrm{CaCO}_{3}$ of TDP Site 38 is low compared to all previous TDP sites, and ranges from $10 \%$ up to $15.7 \%$ (average $=12.4 \% \pm 2.4 \%, 1$ s.d.; Fig. 10 ). This low $\% \mathrm{CaCO}_{3}$ is not associated with high $\% \mathrm{C}_{\text {org }}$, which ranges from $0.3 \%$ to $0.8 \%$ (average $=0.6 \% \pm 0.2 \%, 1$ s.d.). In the $30 \mathrm{~m}$ of drilled core, no significant trends in either ${ }_{0} \mathrm{CaCO}_{3}$ or $\% \mathrm{C}_{\text {org }}$ are observed (Fig. 10).

\subsubsection{Foraminiferal biostratigraphy}

Planktonic foraminiferal assemblages found in TDP Site 38 include specimens of Helvetoglobotruncana helvetica with a flattened spiral side and a well-developed keel on all final whorl chambers. Such advanced forms of $H$. helvetica, together with the presence of Marginotruncana marginata, M. sigali and M. schneegansi, indicate that the recovered interval represents part of the middle to upper $H$. helvetica Zone (middle Turonian; Fig. 10, Table 1; see Huber and Petrizzo, 2014). The specimens observed exhibit moderately- to well-preserved shells. Many of them, 
though, show infillings with calcite or pyrite, and even partly-recrystallised walls. Specimens with glassy preservation are rare.

\subsubsection{Calcareous nannofossil biostratigraphy}

Samples were examined from between the top of the borehole down to $2.15 \mathrm{~m}$ (cores TDP38/1-2), and these were barren of nannofossils. Samples were productive from $4.10 \mathrm{~m}$ to the bottom of the hole at $29.09 \mathrm{~m}$ (cores TDP38/3-13). Preservation is moderate to excellent, but abundance is generally very low. As in TDP36 (and other sites, as noted in Section 4.1.3), the entire section falls into the lower Turonian subzone UC6b, based on the presence of Eprolithus moratus and the absence of younger marker datums; the section may or may not include UC7.

\subsubsection{Chemostratigraphy}

The $\delta^{13} \mathrm{C}_{\text {carb }}$ and $\delta^{18} \mathrm{O}_{\text {carb }}$ values of this section range between $-6.0 \%$ and $-1.3 \%$ (average $=-3.2 \% 0 \pm 1.3 \%$, 1 s.d.) and between $-4.9 \%$ and $-2.2 \%$ (average $=-3.5 \% \pm 0.7 \%$, 1 s.d.), respectively (Fig. 10). The $\delta^{13} \mathrm{C}_{\text {carb }}$ exhibits an increase by $\sim 4 \%$ through the section, whereas the $\delta^{18} \mathrm{O}_{\text {carb }}$ decreases from $17 \mathrm{~m}$ to the top of the recovered section. The $\delta^{13} \mathrm{C}_{\text {org }}$ values range from $-24 \%$ to $-23 \%$ (average $=-23.5 \pm 0.4 \%$ o 1 s.d.) and increase by $\sim 1 \%$ from 20 $\mathrm{m}$ to the top of the recovered section (Fig. 10).

\subsection{TDP Site 39}

TDP Site 39 was drilled $7.8 \mathrm{~km}$ northwest of the Nangurukuru junction, $50 \mathrm{~m}$ southwest of the main road (UTM 37L 532485, 9032440) (Fig. 7). This site is located near the summit of Hill 1 of Nicholas et al. (2006) that is part of the composite stratotype section of the Nangurukuru Fm, from Matandu Bridge (Santonian) along the roadside to the Nangurukuru junction (upper Campanian) (Fig. 7). TDP Site 39 was positioned $390 \mathrm{~m}$ southwest of a surface sample that provided planktonic foraminifera from the Coniacian to Santonian Dicarinella asymetrica Zone. The goal was to recover a complete Coniacian-Santonian section, an interval that had previously yielded only incomplete records near Kilwa and Lindi. Drilling was stopped in Coniacian sediments following good to moderate core recovery of a $101 \mathrm{~m}$ interval of Coniacian-Santonian sediments.

\subsubsection{Lithostratigraphy and bulk sediment composition}

Underlying $1 \mathrm{~m}$ of modern soil (core TDP39/1), the main lithologies in cores TDP39/2-13 are massive, calcareous, clayey siltstones of light olive gray color (Fig. 12). Oxide stains are frequent in cores TDP39/2-6 and decrease in abundance down section through cores TDP39/7 to 13, with core 13 representing the lower limit of modern weathering. From core TDP39/14 to 29, calcareous, clayey siltstones show dark olive gray to dark greenish gray color and generally massive texture (Figs 12, 13a). Noteworthy is that parts of cores TDP39/14-21 and 24-28 exhibit cm-thick, dark gray, possibly clay-rich, intervals with abundant bioturbation (Chondrites) alternating with $\mathrm{cm}$-thick, lighter gray intervals with rare bioturbation (Figs 12, 13b-d). The contacts between these intervals are generally gradational but occasionally sharp. Ongoing TDP studies are examining whether these alternating intervals represent changes in redox conditions near the sediment-seawater interface associated with Ocean Anoxic Event 3, traditionally assigned to the Coniacian-Santonian interval (e.g., Jenkyns, 2010). Slightly inclined or disturbed lamination occurs locally in cores TDP39/18-19. Another remarkable feature of this site is the common presence of $\mathrm{mm}$ - to $\mathrm{cm}$-thick, carbonate-cemented siltstone layers from cores TDP39/14 to 35. They exhibit sharp, irregular bases and, occasionally, ripple-like structures at the top (Figs 12, 13a, e, f). The latter are probably related to bottomcurrent activity.

In contrast, the main lithologies of cores TDP39/30 to 40 are olive gray to olive black, well-lithified, silty claystones (Fig. 12). Massive textures are dominant, but laminated intervals (darker and more clay-rich), similar to those found in Turonian TDP sites (e.g., TDP 22, 24, 31; Jiménez Berrocoso et al., 2010, 2012), are visible in cores TDP39/36-40 (see Fig. 18). Finally, bioclastic debris is only observed in cores TDP39/9-10, whereas mm- to cmsized pyrite nodules are relatively common in this hole.

The $\% \mathrm{CaCO}_{3}$ and $\% \mathrm{C}_{\text {org }}$ content of this site range from $11.8 \%$ to $50.0 \%$ (average $=27.4 \% \pm 11.9 \%, 1$ s.d.) and from $0.1 \%$ to $0.4 \%$ (average $=0.2 \% \pm 0.1 \%, 1$ s.d.), respectively (Fig. 12). At $\sim 68 \mathrm{~m}$, a major increase in 
$\% \mathrm{CaCO}_{3}(20 \%$ shift) is observed across the Dicarinella concavata-D. asymetrica zonal boundary (Fig. 12) and, in the nannofossils, this shift is reflected in a change from low to moderate to high overall abundances, which appears to be a feature of the assemblages from here and up (younger) in all TDP sites. Although the $\% \mathrm{C}_{\mathrm{org}}$ is very low throughout, it decreases by half (from $0.4 \%$ to $0.2 \%$ ) at the level of the major $\% \mathrm{CaCO}_{3}$ increase.

\subsubsection{Foraminiferal biostratigraphy}

All samples studied yield specimens with poor to moderate preservation, with some degree of wall recrystallization and complete shell infilling with calcite or pyrite. Foraminifera are abundant in all samples, with planktonic forms generally occurring in greater abundance than benthic forms. Assemblages from the top of the hole to $70.68 \mathrm{~m}$ (core TDP39/29) are assigned to the Coniacian-Santonian Dicarinella asymetrica Zone (Fig. 12, Table 1), based on the consistent presence of the nominate taxon along with Contusotruncana fornicata and abundant and large-sized marginotruncanids (Marginotruncana sinuosa, M. tarfayensis, M. schneegansi, M. coronata, M. pseudolinneiana). Planktonic foraminifera in this interval are very abundant and show a high rate of diversification, with the appearance of several new genera and species, including Globotruncanita stuartiformis (sample TDP39/292, 1-25 cm), G. elevata (sample TDP39/25-2, 1-25 cm), Globotruncana linneiana (sample TDP39/11-1, 25-54 cm), and Sigalia carpatica (sample TDP39/16-1, 1-24 cm). The rest of the hole, from $70.68 \mathrm{~m}$ to the bottom, is placed in the Coniacian Dicarinella concavata Zone (Fig. 12, Table 1), due to the absence of D. asymetrica and the common to abundant presence of marginotruncanids and dicarinellids. A decrease in species richness is observed from core TDP39/34 to the bottom of the hole. Contusotruncana fornicata occurs from the base (core TDP39/40) to the top of the hole, and the base of Pseudotextularia nuttalli is observed in core TDP39/36.

\subsubsection{Calcareous nannofossil biostratigraphy}

Samples were studied from $0.60 \mathrm{~m}$ (core TDP39/1) to the base of the hole, and all were productive. The nannofossil assemblages were generally excellent and moderate to very well- preserved, with overall abundances generally being very low to low in the lower part of the section and moderate to high in the upper part, from $68.05 \mathrm{~m}$ (core TDP39/29). Zones upper UC10 through lower UC12 were identified in this site, based on the presence of Micula staurophora from the base of the section, base Lithastrinus grillii at $53.05 \mathrm{~m}$, top Lithastrinus septenarius at $21.05 \mathrm{~m}$ and the absence of Arkhangelskiella cymbiformis from the uppermost sample.

\subsubsection{Chemostratigraphy}

The $\delta^{13} \mathrm{C}_{\text {carb }}$ values of this site range from $-1.5 \%$ to $1.7 \%$ (average $=-0.3 \%$. $\pm 0.6 \%, 1$ s.d.) and the $\delta^{18} \mathrm{O}_{\text {carb }}$ from $-6.8 \%$ to $-3.6 \%$ (average $=-4.6 \% \pm 0.7 \%$, 1 s.d.; Fig. 12). While the amount of variation in $\delta{ }^{18} \mathrm{O}_{\text {carb }}$ throughout much of the section is low, an $\sim 1 \%$ decrease can be seen across the Dicarinella concavata-D. asymetrica zonal boundary (Fig. 12) that is correlated with a $20 \%$ increase in $\% \mathrm{CaCO}_{3}$ and an increase in overall abundance of nannofossils. The $\delta^{13} \mathrm{C}_{\text {carb }}$ values fluctuate by 1-2\%o throughout the entire section and show no clear trends. The $\delta^{13} \mathrm{C}_{\text {org }}$ values range from $-24.3 \%$ to $-22.6 \%$ (average $=-23.6 \% \pm 0.4 \%$, 1 s.d.) and, except for a short $2 \%$ positive excursion across the $D$. concavata-D. asymetrica boundary, they generally vary no more than $1-2 \%$ throughout the hole (Fig. 12).

\subsection{TDP Sites $40 A$ and $40 B$}

TDP Site $40 \mathrm{~A}$ was drilled $110 \mathrm{~m}$ east of the main road, $43 \mathrm{~km}$ south of the Nangurukuru junction (UTM 37L 540908, 8984449). The site was located next to a surface sample that contained the lower-middle Albian planktonic foraminifera Ticinella primula, and the main goal was to try to recover a complete Aptian-Albian boundary interval. The site was drilled to $88.45 \mathrm{~m}$, with good to moderate recovery from the surface to $60.82 \mathrm{~m}$, and moderate to poor recovery from $60.82 \mathrm{~m}$ to the bottom of the hole. Drilling was terminated in lithified sandstones of uncertain age. TDP Site 40B was positioned $170 \mathrm{~m}$ south of TDP Site 40A, and the main goal was to recover foraminifera in higher abundances and with better preservation than TDP Site 40A, which had yielded a low number of poorly-preserved specimens. TDP Site 40B was drilled to $70 \mathrm{~m}$, with good recovery from the top to $60 \mathrm{~m}$ and low recovery from $60 \mathrm{~m}$ to the bottom of the hole. Drilling again terminated in lithified sandstones. 


\subsubsection{Lithostratigraphy and bulk rock geochemistry}

The uppermost $5 \mathrm{~m}$ of TDP Site 40A shows weathered, massive, sandy claystones and siltstones, with sporadic calcrete nodules. From 5 to $26.12 \mathrm{~m}$ (cores TDP40A/4-11), lithologies are dark olive black and greenish black, massive to weakly-bedded, calcareous siltstones, with sporadic, cm-thick, clay-rich intervals and irregular bioturbation mottling (Figs 14a, 15a). In this interval, at least two layers of light gray, partly conglomeratic, calcareous sandstones, with $\mathrm{mm}$ - to $\mathrm{cm}$-sized mud clasts, are visible $(16.05 \mathrm{~m}$ and $18.25 \mathrm{~m}$; cores TDP40A/8-9; Figs. 14a, 15b). A thin-section from core TDP40A/10, at $22.80 \mathrm{~m}$, shows that the calcareous siltstones have abundant, angular to sub-rounded, monocrystalline, fine to medium quartz grains in a carbonate matrix in which rare to common disseminated pyrite is present (Fig. 16a). A thin-section from the partly conglomeratic, calcareous sandstones, however, reveals carbonate-cemented, rounded to sub-rounded, coarse-grained quartz with little carbonate matrix (Fig. 16b). Shelly debris was also observed in the sandstones in thin-section. Together, these sandstones are interpreted as the result of episodes of increased transport of sand and bioclasts offshore by bottom currents that ripped up mud-clasts from a semi-lithified seafloor.

From $26.12 \mathrm{~m}$ to $60.40 \mathrm{~m}$ (cores TDP40A/12-23), the main lithologies are greenish black, massive, moderately- to intensely-bioturbated, calcareous, silty claystones and siltstones, with sporadic to common bioclasts (Figs. 14a, 15c, 16c). Belemnite guards (cm-sized) occur at $30.20 \mathrm{~m}, 31.34 \mathrm{~m}$ and $43.12 \mathrm{~m}$, and ammonite shell remains from $46.60 \mathrm{~m}$ to $46.79 \mathrm{~m}$. Also, scattered, mm-sized pyrite nodules are visible in cores TDP40A/12, 19 and 20 (Fig. 15d). From $60.40 \mathrm{~m}$ to $60.82 \mathrm{~m}$ (core TDP40A/23), an interval with up to boulder-sized, polygenic conglomerates was cored (Figs 14a, 15e, 16d). These conglomerates are a major lithological change in TDP Site $40 \mathrm{~A}$ and their top is interpreted as a break in sedimentation (i.e., an unconformity). From $62.45 \mathrm{~m}$ to $69.02 \mathrm{~m}$ (cores TDP40A/24-26), lithologies are greenish gray, massive, medium- to coarse-grained, calcareous sandstones, with common plant debris and sporadic bioclasts. At $69.02 \mathrm{~m}$ (core TDP40A/26), a sharp contact gives way to an interval with grayish black, massive to weakly-bedded, moderately- to intensely-bioturbated, fine-grained, calcareous sandstones and siltstones, with common mm- to cm-sized plant debris to the bottom of the hole (Figs 14a, 15f).

TDP Site 40B exhibits weathered, massive to weakly-bedded, silty claystones from $0 \mathrm{~m}$ to $14 \mathrm{~m}$ (cores TDP40B/1-6), with occasional bioturbation mottling, pyrite nodules and calcite veins (Fig. 14b). From $14 \mathrm{~m}$ to $58.36 \mathrm{~m}$ (cores TDP40B/7-22), lithologies are olive gray and dark greenish gray, massive to weakly bedded, calcareous, silty claystones, with sporadic plant debris. This interval is moderately bioturbated and shows common, $\mathrm{mm}$-sized, pyrite nodules scattered in the lower part, and an ammonite shell fragment at $38.54 \mathrm{~m}$ (Fig. 14b). Also, between the bottom of core TDP40B/7 and the top of core TDP40B/8 (from 15.80-17.58 m), massive, mediumgrained, calcareous sandstones are visible (Fig. 14b), which are interpreted as the lateral equivalent to the calcareous sandstones of cores 8 to 9 of TDP Site 40A (Fig. 14a).

A sharp, irregular surface at $58.36 \mathrm{~m}$ marks the contact with the much coarser sediments that occur below core TDP40B/22 down to the bottom of the hole (Fig. 14b). An interval with up to boulder-sized conglomerates was observed from $58.36 \mathrm{~m}$ to $58.71 \mathrm{~m}$ (lower part of core TDP40B/22). These conglomerates represent the lateral equivalent to the conglomeratic interval of core 23 from TDP Site 40A (Fig. 14a). As in TDP Site 40A, because the conglomerates constitute a major lithological change in TDP Site 40B, their top is interpreted as an unconformity. From $58.71 \mathrm{~m}$ to the bottom of the hole, lithologies are greenish gray to black, massive, medium- to coarse-grained, calcareous sandstones. A conglomeratic interval was observed between $68.24 \mathrm{~m}$ and $68.34 \mathrm{~m}$ (Fig. 14b).

In TDP Site $40 \mathrm{~B}, \% \mathrm{CaCO}_{3}$ ranges from $3.8 \%$ to $24.0 \%$ (average $=9.6 \% \pm 4.1 \%, 1$ s.d.) and the $\% \mathrm{TOC}$ from $<0.1 \%$ up to $0.5 \%$ (average $=0.2 \% \pm 0.1 \%, 1$ s.d.). The two metrics do not show any interdependence and apparently have no relationship with the above lithological changes (Fig. 14b). The \%TOC is generally low $(<0.1 \%)$ between 0 and $12 \mathrm{~m}$. From $12 \mathrm{~m}$ to the bottom of the hole, the values fluctuate around a mean of $\sim 0.3 \%$. The highest $\%$ TOC occurs between 23 and $25 \mathrm{~m}$, an interval showing slightly laminated fabrics. The $\% \mathrm{CaCO}_{3}$ record shows no obvious trends with depth (Fig. 14b), although, in general, lower values occur towards the top of the core.

Based on biostratigraphy (see below), the sediments of TDP Sites 40A and 40B (Barremian-middle Albian) were partly deposited during formation of the Aptian-Albian Kihuluhulu and Kingongo Marls (Balduzzi et al., 1992; Veeken and Titov, 1996; Nicholas et al., 2006), the latter attributed to a coastal to shallow marine setting (Veeken 
and Titov, 1996). A similar upper shoreface setting was assigned to the Aptian-Albian interval of the gas-bearing subarkosic sandstones of the Songo Songo field (Williams, 2009) (Fig. 1), located $\sim 150 \mathrm{~km}$ south of and overlapping in time of deposition with TDP Sites 40A and 40B. Our lithological data (i.e., a sequence dominated by calcareous claystones and siltstones with varying abundances of bioturbation, bioclasts and plant debris) indicate that deposition of TDP Sites 40A and 40B occurred in a marine setting with relatively high terrigenous input and at which sediment supply varied through time. Specifically, coarser lithologies (i.e., sandstones and conglomerates), interpreted to correspond to greater input from shallower and/or continental areas, are more frequent from the base of the holes up to the unconformity at the top of the conglomerates of cores TDP40A/23 and TDP40B/22 (Fig. 14a, b). Above this unconformity, finer lithologies were observed, suggesting relatively lower sediment input and/or a change in relative sea level. More subsurface data would be needed to make a comprehensive bio- and lithostratigraphic correlation between TDP Sites 40A and 40B and the reservoirs of the Songo Songo field. Regardless, compared to the Lindi Fm (upper Albian-Coniacian) (see below), the marine sediments of the Barremian-middle Albian of the Tanzanian margin probably experienced higher-energy depositional conditions.

\subsubsection{Foraminiferal biostratigraphy}

Because of the proximity of TDP Sites 40A and 40B, only the more resolved foraminiferal data from TDP Site 40A is described here (Fig. 14a). Preservation of foraminiferal tests in TDP Site 40A varies from poor to good and all shells are filled with calcite. The succession is divided into three intervals that differ in foraminiferal assemblage composition. The intervals are bounded by (1) the calcareous sandstones with mud-clasts between 16.05-18.25 m, and (2) the boulder-sized, polygenic conglomerates between 60.40 and $60.82 \mathrm{~m}$ (Fig. 14a). The top interval is assigned to the upper Aptian to lower-middle Albian and yields moderately abundant and diverse planktonic foraminifera. The biostratigraphy is only tentatively applied in this interval, since some of the index taxa and secondary markers are very rare. The middle unit is attributed to the Barremian-lower Aptian (Fig. 15a), based on moderately abundant and diverse benthic foraminifera. Few planktonic foraminifera have been found in this interval, a situation that prevents more refined foraminiferal age assignments. The bottom interval is barren of both benthic and planktonic foraminifera.

In the upper interval, the lower-middle Albian Ticinella primula Zone is defined from the top of the hole down to $6.25 \mathrm{~m}$ (Fig. 14a), due to the presence of relatively abundant $T$. primula and the absence of Biticinella breggiensis. Other planktonic foraminifera found in this zone are T. roberti, Favusella washitensis and rare $T$. madecassiana, Microhedbergella rischi, and M. pseudoplanispira. The T. primula Zone is underlain by an interval that contains only M. praelippa and M. renilaevis and extends down to $8.65 \mathrm{~m}$ (Fig. 14a). The presence of $M$. renilaevis, a small-sized species whose appearance level is considered a good proxy for placing the Aptian/Albian boundary (Huber and Leckie, 2011; Petrizzo et al., 2012, 2013), confirms the assignment of this interval to the lower Albian M. rischi Zone. The T. madecassiana Zone, which should be found between the T. primula and M. rischi Zones, is not identified in TDP Site 40A (based on the absence of T. madecassiana) likely because of a hiatus spanning part of the lower Albian at $6.25 \mathrm{~m}$ (Fig. 14a). The upper Aptian Paraticinella rohri Zone (P. eubejaouaensis Zone, see Ando et al., 2013) is assigned to 8.65 to $11.09 \mathrm{~m}$ (Fig. 14a) and contains Hedbergella gorbachikae and H. trocoidea. The upper Aptian H. trocoidea Zone is identified from 11.09 to $15.55 \mathrm{~m}$ (Fig. 14a) and includes occurrences of $H$. infracretacea, H. excelsa, and H. gorbachikae.

The middle interval (Barremian-lower Aptian; 18.25-60.40 m) is bounded at the top by calcareous sandstones (from 16.05-18.25 m) that are barren of foraminifera (Fig. 14a). Below the sandstones, the sediments yield a depauperate planktonic foraminiferal assemblage that includes Hedbergella aptiana, Gorbachikella kugleri, Caucasella hoterivica and Globigerinelloides blowi. Benthic foraminifera in this unit include calcareous species assigned to Lenticulina, Gavelinella, Gyroidinoides, Conorotalites and Epistomina, as well as various agglutinated species. Gavelinella barremiana and Conorotalites bartensteini intercedens, species attributed to the Barremianlower Aptian by Bartenstein and Bettenstaedt (in Bolli et. al., 1994), were observed in this interval (Fig. 14a). 


\subsubsection{Calcareous nannofossil biostratigraphy}

Six samples from TDP Site 40A and 18 samples from TDP Site 40B were studied, all with frequent to abundant calcareous nannofossils and predominantly good to excellent preservation. The assemblages are exceptionally diverse and yield species richness values between 54 and 80 per sample (67 average), with $\sim 171$ species present in total. These values are far higher than typically observed for this time interval, and higher than the global compilation of Bown et al. (2004). The quality of preservation is evident from the presence of abundant small coccoliths (especially Biscutum and Zeugrhabdotus) and conspicuous fragile taxa (e.g., Calciosolenia), especially holococcoliths (e.g., Owenia, Orastrum).

Because of the proximity of the two holes, only the more refined calcareous nannofossil data of TDP Site 40B is described below (Fig. 14b). Similar to the planktonic foraminiferal biostratigraphy (Fig. 14a), this site can be divided into three distinct intervals using calcareous nannofossil assemblages. They correspond to an upper interval assigned to the lower Albian that overlies a middle interval from the uppermost Barremian-lower Aptian that is underlain by a lower interval barren of calcareous nannofossils (Fig. 14b).

The upper interval (core TDP40B/7 and higher; Fig. 14b) contains abundant and diverse assemblages with taxa that first appear around the Aptian-Albian boundary and characterize lower zone NC8 (e.g. Prediscosphaera columnata, Cylindralithus nudus, Laguncula, Helicolithus trabeculatus). The Aptian-Albian boundary is currently not defined by a Global Stratotype Section and Point, but Kennedy et al. (2000) proposed a level close to the base of P. columnata sensu stricto, which is present throughout this upper interval at TDP Site 40B, but not present below. The base of the lower Albian at this site is marked by 11 base datums and 6 top datums, which is strongly suggestive of a significant hiatus that incorporates the lowermost part of NC8 (uppermost Aptian/lowermost Albian) and NC7 (upper Aptian). Just underlying the base of the lower Albian in TDP Site 40B (Fig. 14b), medium-grained, calcareous sandstones barren of microfossils occur between the bottom of core TDP40B/7 and the top of core TDP40B/8 (from 15.80-17.58 m; Fig. 14b).

The middle interval (cores TDP40B/8 through 22; Fig. 14b) contains assemblages that include Hayesites irregularis, Flabellites oblongus and Retecapsa angustiforata. The co-occurrence of these taxa defines NC6 of the uppermost Barremian-lower Aptian (Fig. 14b). The top of Conusphaera rothii was used to subdivide NC6 into subzones NC6B and NC6A by Bralower et al. (1993) and, although this species is rare and sporadic in TDP Site 40B, its top is found at $32 \mathrm{~m}$ (sample TDP40B/14-1, $0 \mathrm{~cm}$; Fig. 14b). Furthermore, a marked abundance decline in nannoconids occurs at $35 \mathrm{~m}$ (towards the top of Subzone NC6A; Fig. 14b), which is coincident with a decline in the neritic braarudosphaerid genera Micrantholithus and Braarudosphaera. A number of nannoconid acmes and declines have been documented from the Aptian and Albian (e.g., Herrle, 2002) and in several cases they have been linked with significant paleoceanographic perturbations, such as ocean anoxic events. A full understanding of the paleoecology of nannoconids remains elusive (Bown, 2005b), however, and the decline at TDP Site 40B, along with the braarudosphaerids, is intriguing. One possibility, supported by the position of this decline within NC6, is that it may be an expression of the early Aptian so-called 'nannoconid crisis' (Erba, 1994), which was associated with OAE 1a. That event was accompanied by an increase in large Assipetra terebrodentarius (subsp. youngii), which is also conspicuous (but not common) in cores TDP40B/13 through 8 (Fig. 14b).

\subsubsection{Chemostratigraphy}

The $\delta^{13} \mathrm{C}_{\text {carb }}$ and $\delta^{18} \mathrm{O}_{\text {carb }}$ of TDP Site $40 \mathrm{~B}$ range from $-6.1 \%$ to $-2.3 \%$ (average $=-3.3 \%$ o $\pm 0.7 \%$, 1 s.d.) and from $-7.2 \%$ to $-3.4 \%$ (average $=-4.5 \% \neq \pm 0.6 \%, 1$ s.d.), respectively. Although no clear stratigraphic patterns are observed in the two metrics, some fluctuations occur and, in some cases, they seem to be similar in magnitude (from 1 to $\sim 5 \%$ ) and slope (i.e., increasing or decreasing values) (Fig. 14b). The $\delta^{13} \mathrm{C}_{\text {org }}$ values range from $-27.8 \%$ to $-24.2 \%$ (average $=-26.3 \% \pm 0.8 \%$, 1 s.d.) and generally exhibit no clear stratigraphic patterns except for cores TDP40B/17 to 14 . Here, the $\delta^{13} \mathrm{C}_{\text {org }}$ profile gradually decreases by $\sim 1.5 \%$ and then increases by $\sim 2.5 \%$ up to the top of subzone NC6A in core TDP40B/14 (Fig. 14b). Superimposed on these fluctuations, a sharp increase in $\delta^{13} \mathrm{C}_{\text {org }}$ is detected in core TDP40B/16. Together, these $\delta^{13} \mathrm{C}_{\text {org }}$ changes occur near the nannoconid and braarudosphaerid declines highlighted above and investigations are underway to examine whether they are associated with OAE 1a. Higher in the section, two steps towards higher and lower values, respectively, occur near $15 \mathrm{~m}$ and $10 \mathrm{~m}$ (Fig. 14b). 


\section{Discussion}

In this section, we propose a new unit (Lindi Fm) for the Kilwa Group (Nicholas et al., 2006) and discuss the significance of the microfossil assemblages and chemostratigraphic trends observed in the Upper Cretaceous samples from the 2009 TDP sites.

\subsection{The Lindi Fm}

Cores recovered during 2007 to 2009 have provided a wealth of regional litho-, bio- and chemostratigraphic data from the Upper Cretaceous of southeastern Tanzania. We found that the post-Albian to preSantonian interval (1) showed key lithological differences (see below) relative to the overlying units, and (2) was both geographically more widespread and biostratigraphically more expanded (Jiménez Berrocoso et al., 2010, 2012; Wendler et al., 2011, 2013; Huber and Petrizzo, 2014) than appreciated in previous studies (e.g., Schlüter, 1997; Nicholas et al., 2006, 2007). For these reasons, we propose a new unit, the Lindi Fm, as the unit that forms the base of the Kilwa Group (Nicholas et al., 2006) in southeastern Tanzania (Fig. 2). We use the name 'Lindi' for the new formation since the majority of our data belong to subsurface sections and, less frequently, outcrops near Lindi, which is herein considered the type area of the Lindi Fm.

The Kilwa Group was proposed to represent a generally homogeneous sedimentary package dominated by mudstones that accumulated during a period of increased subsidence of a passive margin in southeastern Tanzania from the Late Cretaceous to Paleogene (Nicholas et al., 2006). Because clay and silt sized grains dominate the Lindi Fm (see Table 2 for lithologies of the Lindi Fm versus other units of the Kilwa Group), we include the Lindi Fm in the Kilwa Group. Nicholas et al. (2006) indicated that the Santonian-Maastrichtian Nangurukuru Fm represented the base of the Kilwa Group and suggested that its basal surface should lie at the lowest level of Santonian sediments. Below, a 'separate stratigraphic unit' (post-Albian to pre-Santonian) with one or more disconformities would overlie the Aptian-Albian Kihuluhulu and Kingongo Marls (Balduzzi et al., 1992; Nicholas et al., 2006). The Lindi Fm proposed here underlies the Nangurukuru Fm (Nicholas et al., 2006), includes the above-mentioned 'separate stratigraphic unit', and extends the lower limit of the Kilwa Group from the Santonian to at least the upper Albian (see below; Fig. 2).

\subsubsection{Lithologies}

Five distinct lithofacies were recognized in the upper Albian-upper Campanian TDP sediments drilled in 2007 and 2008 (Jiménez Berrocoso et al., 2010, 2012). Here, we integrate part of these lithofacies with the sediments cored in 2009 and establish one single facies association that defines the Lindi Fm (Table 3).

This facies association consists of the upper Albian to Coniacian lithofacies 2, 3, and 4 of Jiménez Berrocoso et al. $(2010,2012)$. Lithofacies 2 (and 4) represents mm- to cm-thick interbeds of dark gray to black claystones and siltstones ( $\sim 90 \%$ of the facies association), with common finely-laminated, possibly organic-rich, intervals (Fig. 17b, c). Discrete intervals with soft-sediment deformation (slightly inclined, convoluted, and highlydisturbed laminations) are common in the lower-middle Turonian, but they are rare or completely absent in the rest of the upper Albian-Coniacian. Lithofacies 3 exhibits cm-thick beds of brownish gray, lithified, fine- to coarsegrained sandstones ( $\sim 10 \%$ of the facies association; see fig. 5e, f of Jiménez Berrocoso et al., 2010). These sandstones are generally massive, but examples with wavy lamination at the top have sporadically been observed. Noteworthy is that, unlike the sandstones of lithofacies 1 of Jiménez Berrocoso et al. (2010, 2012), soft clasts were not observed in the sandstones of lithofacies 3. In other words, soft clasts seem to be only present in the sandstones of lithofacies 1. Because the sandstones of the upper part of TDP Site 33 (cores TDP33/1-10; see fig. 11 of Jiménez Berrocoso et al., 2012) do not show soft clasts and occur in lower Cenomanian siltstones, here we re-interpret that the upper part of TDP Site 33 belongs to lithofacies 3 of the Lindi Fm. Finally, whereas bioturbation mottling is rare or absent in the facies association of the Lindi Fm, planktonic microfossils (i.e., calcareous nannofossils and foraminifera) are common and exquisitely preserved in many intervals. Ammonite, inoceramid and gastropod shell debris are sporadically present. 


\subsubsection{Type section and biostratigraphy}

The facies association of the Lindi Fm is best observed in the sites drilled near Lindi. Among them, TDP Sites 22 and 24 (Jiménez Berrocoso et al., 2010), TDP Site 31 (Jiménez Berrocoso et al., 2012) and the bottom of TDP Site 39 (this study) together comprise a 335-m-thick composite section that spans the majority of the stratigraphy of the Lindi Fm (upper Albian to Coniacian) (Fig. 18), with good recovery in most of the intervals. We thus propose a subsurface composite stratotype for the Lindi Fm consisting of parts of these four sites (Fig. 18).

The oldest portion of the Lindi Fm belongs to TDP Site 24 (Figs 17d, e, 18), is assigned to the upper Albian Planomalina buxtorfi Zone (cores TDP24/27 to 25), and overlies an interval of the same age with mostly lithified sandstones (cores TDP24/28 to 30; see Section 5.1.4 for details of the base of the Lindi Fm). At this site, the sediments of the Lindi Fm are mainly composed of claystone and siltstone interbeds (lithofacies 2) and show a younger age of early Turonian (Whiteinella archaeocretacea Zone and UC6a; Fig. 19). A few layers of cm-thick, fine sandstones (lithofacies 3) occur near the top of the borehole (Fig. 18) and are similar to sandstone beds cored at equivalent stratigraphic positions in the nearby TDP Sites 24B and 26 (Jiménez Berrocoso et al., 2010). Contrary to data reported in Jiménez Berrocoso et al. (2010) for this site, the transition from the upper Albian P. buxtorfi Zone to the lower-middle Cenomanian Thalmanninella globotruncanoides Zone (previously identified as Rotalipora cushmani Zone in Jiménez Berrocoso et al., 2010) is now determined to be conformable. An unconformity, though, occurs in the upper part of the site, between the lower-middle Cenomanian T. globotruncanoides Zone and the lower Turonian W. archaeocretacea Zone (Fig. 18).

TDP Site 22 preserves Lindi Fm strata from the lower Turonian Whiteinella archaeocretacea Zone (and UC6b) to the lower-middle Turonian Helvetoglobotruncana helvetica Zone (still UC6b; Fig. 18) that consist of claystone and siltstone interbeds with finely-laminated, possibly organic-rich intervals (lithofacies 2; Jiménez Berrocoso et al., 2010). Common soft-sediment deformation is observed in the lower and middle parts of this borehole. The base of TDP Site 22 is similar in age (lower Turonian $W$. archaeocretacea Zone) to the top of TDP Site 24 (Fig. 18), although the nannofossils suggest a slight offset (older UC6a at TDP Site 24 versus UC6b at TDP Site 22). However, the absence of correlatable marker beds and/or foraminiferal bioevents prevents a tight correlation between the two sites. An ongoing high-resolution nannofossil study may resolve this situation further.

TDP Site 31 spans the lower-middle Turonian Helvetoglobotruncana helvetica Zone (and UC6b) to the Coniacian Dicarinella concavata Zone (UC9b) and shows the characteristic claystone and siltstone interbeds of the Lindi Fm in most of the cores (Fig. 18), with soft-sediment deformation mainly present in the lower-middle Turonian. A bed-by-bed correlation between the bottom of TDP Site 31 and the top of TDP Site 22, both portions assigned to the same age (lower-middle Turonian H. helvetica Zone and UC6b), is not possible due to the absence of distinctive marker beds and/or discrete foraminiferal bioevents, but the ongoing high-resolution nannofossil study may provide a greater degree of correlation. Note that Huber and Petrizzo (2014) proposed a refined the biostratigraphy for TDP Sites 22 and 31. In TDP Site 22, the section assigned to the lower Turonian Whiteinella archaeocretacea Zone in Huber and Petrizzo (2014) is thinner than in Jiménez Berrocoso et al. (2010). In TDP Site 31 , the lower part of the section, previously assigned to the $W$. archaeocretacea Zone (Jiménez Berrocoso et al., 2012), is now attributed to the lower-middle Turonian H. helvetica Zone in Huber and Petrizzo (2014) (Fig. 18).

The youngest portion of the Lindi Fm was recovered at TDP Site 39 and is assigned to the Coniacian Dicarinella concavata Zone and UC10 (cores TDP39/29 to 40; Figs. 12, 18). Correlation of this site with TDP Site 31 is based on the datum base Pseudotextularia nuttalli (Fig. 18), although the nannofossils indicate a gap between the top of TDP Site 31 and the base of TDP Site 39, based on the respective absence and then presence of Micula staurophora. At TDP Site 39, the Lindi Fm (cores TDP39/29 to 40) mainly exhibits olive gray to olive black, silty claystones, with some laminated, darker and more clay-rich intervals (cores TDP Site 39/36 to 40; Fig. 17b), similar to the laminated mudstones of the Turonian boreholes (e.g., TDP Sites 24, 22 and 31; see Section 5.1.4 for boundaries of the Lindi Fm).

Other TDP sites assigned to the Lindi Fm have been drilled near Lindi (e.g., TDP Sites 26 and 33) and Kilwa (e.g., TDP 38), the two localities separated by $\sim 120 \mathrm{~km}$. Also, surface exposures, albeit of generally low quality, and petroleum wells between Kilwa and Lindi have shown similar lithologies spanning the same biostratigraphic intervals as those here associated with the Lindi Fm (see Moore et al., 1963; Kent et al., 1971; 
Gierlowski-Kordesch and Ernst, 1987; Ernst and Schlüter, 1989; Balduzzi et al., 1992; Ernst and Zander, 1993; Mpanda, 1997). As emphasized by Nicholas et al. (2006), this situation suggests a remarkable lateral and stratigraphic continuity of the units of the Kilwa Group, including the Lindi Fm, across southeastern Tanzania.

\subsubsection{Depositional setting}

The apparent lateral continuity of the Lindi Fm and the consistent presence of an open marine biota (e.g., common planktonic microfossils and sporadic ammonites and inoceramids) suggest that the Lindi Fm was deposited in an outer shelf-upper slope setting that extended at least $\sim 120 \mathrm{~km}$ along the Tanzanian margin. The predominance of clay- and silt-grained lithologies and the complete absence of storm-related sedimentary structures (e.g., hummocky-cross lamination) suggest that this depositional setting experienced conditions of relatively low energy most of the time and was located below the storm-wave base level. Dominant sedimentary processes were surfaceto mid-water flows that held fine particles in suspension until dilution of the flows allowed these particles to settle. Much less frequent were the sedimentary processes that formed the massive sandstones (lithofacies 3) of the Lindi Fm. They are interpreted as due to discrete periods of higher energy and transport of sand offshore by bottom currents. The fact that some of the sandstones are top-laminated suggests that these currents could have been turbulent flows.

Similar sedimentary conditions could have occurred during deposition of the Santonian-Maastrichtian TDP Sites 23, 28, 32, 35 and 37 (Jiménez-Berrocoso et al., 2010, 2012; Falzoni and Petrizzo, 2011; Petrizzo et al., 2011; Falzoni et al., 2013). Yet, a remarkable difference between these sites and the Lindi Fm (upper Albian-Coniacian) is the relative abundance of bioturbation. Common bioturbation in the Santonian-Maastrichtian (Jiménez Berrocoso et al., 2010, 2012, herein) suggests periods of increased oxygenation and/or nutrients at the seafloor for burrowing organisms. This interval is also associated with higher general abundance of nannofossils and/or lower sedimentary dilution of nannofossil assemblages. Lower levels of burrowing activity are indicated during deposition of the Lindi Fm by its undisturbed $\mathrm{mm}$ - to $\mathrm{cm}$-thick interbeds of claystones and siltstones (lithofacies 2), often showing finelylaminated intervals. Furthermore, unlike the Santonian-Maastrichtian sites, the Lindi Fm has common intervals with soft-sediment deformation in the lower-middle Turonian that indicate formation of slump-prone deposits (JiménezBerrocoso et al., 2010, 2012).

\subsubsection{Top and bottom boundaries}

Establishing a physical boundary between the Lindi Fm and the overlying Nangurukuru Fm is difficult because of the similarity in dominant grain sizes; both units are dominated by clay and silt (Nicholas et al., 2006; Jiménez Berrocoso et al., 2010, 2012). Similarly, whereas the Lindi Fm generally has lower $\% \mathrm{CaCO}_{3}$ than the Nangurukuru Fm (Fig. 19) and there are other subtle but key lithological changes in moving from the Lindi Fm into the Nangurukuru Fm (see Tables 2 and 3), there is no sharp physical contact between the two units. Thus, a gradational top boundary is proposed for the Lindi Fm and it is placed in cores 28 to 30 of TDP Site 39 (Figs. 12, 18), near the boundary between the Dicarinella concavata and D. asymetrica Zones, and where nannofossils become more abundant in the younger sediments. Above core TDP39/30, calcareous, clayey siltstones are dominant, whereas lithologies below correspond to progressively darker, silty claystones, with the distinct laminated intervals of the Lindi Fm present in cores TDP39/36 to 40 (Figs. 12, 17b). A sharp increase in $\% \mathrm{CaCO}_{3}$ from the Lindi Fm into the Nangurukuru Fm occurs close to the same biozonal boundary (Fig. 12) and may be similarly used to recognized the top portion of the Lindi Fm. Investigations are underway to understand the origin of this $\% \mathrm{CaCO}_{3}$ increase. It may represent an important change in sedimentation and/or paleoceanographic conditions within the basin, since the samples analysed from the sites of the Lindi Fm (e.g., TDP Sites 21, 26, 29, 30, 31, 33, 34, 36, 38, 39 ) tend to have lower $\% \mathrm{CaCO}_{3}$, and higher \%TOC, than those of the Nangurukuru Fm (e.g., TDP Sites 28, 32, 35, 37, 39; Fig. 19).

The oldest bottom boundary of the Lindi Fm is in the lowest portion of core 27 (Fig. 17d) of TDP Site 24 (Fig. 18), in contact with an underlying interval with light gray, lithified, fine to coarse sandstones alternating with greenish gray siltstones (cores TDP24/28 to 30; Fig. 17e). This lithological contrast (Fig. 17d, e) is accompanied by a major change in microfossil preservation, with most foraminifera in the underlying sandstone interval showing 
shell recrystallization and calcite or pyrite infilling, compared to the abundance of excellent preservation in the Lindi Fm (Jiménez Berrocoso et al., 2010, 2012). Because both the lowest portion of the Lindi Fm and the underlying sediments are assigned to the upper Albian P. buxtorfi Zone (Figs 18, 20), a conformable bottom contact is determined for the Lindi Fm at TDP Site 24.

Similar to TDP Site 24, TDP Sites 21, 33 and 36 have lithified sandstones underlying the Lindi Fm. However, these sandstones are barren of microfossils and the overlying portions of the Lindi Fm range from the early Cenomanian to the early Turonian (Fig. 20). A possibility to explain this contact is that post-depositional tectonism faulted the bottom of the Lindi Fm at TDP Sites 21, 33 and 36 and produced a structural contact with underlying lithified sandstones of pre-Cenomanian age (Fig. 20). This scenario is supported by the recognition of structural complexities (e.g., surface faulting, repeated stratigraphy in TDP Site 21) in the area of these sites (Jiménez Berrocoso et al., 2010, 2012). A hiatus and/or erosion of unknown duration at the base of, or within, the Lindi Fm at these sites is possible (based on the age range of such a bottom), but this cannot be evaluated without age determinations for lithified sandstones and underlying sediments. Regardless, a complete and conformable basal contact of the Lindi Fm is observable in TDP Site 24 and should be considered the oldest portion (late Albian) of this unit.

\subsection{Significance of the planktonic foraminifera}

The abundance and diversity of planktonic foraminifera from most samples of the 2009 season enable age control for all recovered intervals, except for the sandstone units at the bottom of TDP Sites 36 (Fig. 5), 40A and 40B (Fig. 14a, b), which are barren of microfossils. Good to excellent foraminiferal preservation in the lower-middle Turonian of TDP Site 36 and moderate to excellent preservation in the middle Turonian of TDP Site 38 (Fig. 10) will enable reliable carbon and oxygen stable isotope measurements. In contrast, moderate to good foraminiferal preservation is observed in TDP Sites 37 (lower Maastrichtian-middle Paleocene; Fig. 8a, b), 39 (ConiacianSantonian; Fig. 12), and 40A and 40B (Barremian-middle Albian; Fig. 14a, b), in which nearly all tests are infilled with calcite, a situation that likely precludes interpretation of isotopic results as approximating values in equilibrium with contemporaneous seawater.

A biostratigraphically complete Coniacian-Santonian sequence (TDP Site 39; Fig. 12), an expanded lowerupper Maastrichtian section (TDP Site 37; Figs 8a, b), and a section spanning part of the Barremian-middle Albian (TDP Sites 40A and 40B; Fig. 14a, b) were recovered for the first time in Tanzania in 2009. Despite frequent calcite infilling of shells in TDP Sites 37 and 39, shell preservation is unusually good compared to Coniacian-Santonian and Maastrichtian foraminifera from localities elsewhere. Detailed study of the planktonic assemblages of these sites will present an excellent opportunity for characterizing evolutionary changes and reconstructing the phylogenetic history from these time periods. The Barremian-middle Albian of TDP Sites 40A and 40B is interrupted with at least three unconformities (Fig. 14a, b). In addition to the effects of these unconformities, study of the foraminiferal assemblages from these boreholes is hampered by severe shell infilling, wall recrystallization, and absence or rarity of age-diagnostic species.

\subsection{Significance of the calcareous nannofossils}

The TDP sites drilled in 2009 have filled in significant gaps in the Cretaceous stratigraphy of southeastern Tanzania. Such a situation will be used to study the high-resolution nannofossil biostratigraphy of a composite Cenomanian-Maastrichtian Tanzanian section, albeit incomplete most significantly in the upper Cenomanian and upper Maastrichtian, with the intention of documenting new, and highlighting extended ranges of established, stratigraphically-useful taxa, due to the oftentimes exquisite preservation in these sediments, for use as a lowlatitude biostratigraphic reference section. Work is in progress to tie this composite section in with (sub)stage boundary stratotype sections, so that we can address the mis-match between the age-assignments for nannofossil and planktonic foraminifera zones that can be seen throughout this and the previous TDP syntheses of Jiménez Berrocoso et al. $(2010,2012)$. In tandem with these works, a related study will document the shifts in assemblage proportions that will shed light on paleoceanographic changes in the surface waters that will help us to interpret the isotopic data in terms of long-term environmental change. 
The combination of excellent nannofossil preservation and expanded sedimentary intervals is being used to examine evolutionary patterns that have previously been obscured by indifferent and patchy preservation and interrupted sedimentation, and has also revealed new taxa that provide insights into the evolutionary roots of certain Cenozoic taxa. Scanning electron microscopy is revealing architectural features previously unseen in nannofossils of this age and is also providing insights into the ecological relationships between taxa deposited as fecal pellets.

\subsection{Chemostratigraphic trends}

Consistent with extreme global warmth in the Turonian and Santonian, the $\delta^{18} \mathrm{O}_{\text {carb }}$ of TDP Sites 36,38 and 39 generally falls between $-3.5 \%$ and $-5 \%$ (Figs $5,10,12$ ). The $\delta{ }^{18} \mathrm{O}_{\text {carb }}$ slightly increases to $\sim-3 \%$ and remains relatively constant throughout much of the Maastrichtian of TDP Site 37 (Fig. 8a, b), reflecting cooler conditions at this time. The concurrent $1.5 \%$ increase in $\delta^{13} \mathrm{C}_{\text {carb }}$ and $\sim 0.5 \%$ increase in $\delta^{13} \mathrm{C}_{\text {org }}$ in the Maastrichtian site, relative to those of the Turonian-Santonian, may also be related to a global shift in climate during the Maastrichtian or to local changes in paleoceanographic conditions.

Turonian trends in the isotopic composition of bulk carbonate and organic carbon are apparent and comparable among various TDP sites. A broad negative excursion in the $\delta^{13} \mathrm{C}_{\text {org }}$ was found near the Whiteinella archaeocretacea-Helvetoglobotruncana helvetica boundary (close to, but above, the C-T boundary) of TDP Sites 30 and 34 (Jiménez Berrocoso et al., 2012). A similar negative excursion in the $\delta^{13} \mathrm{C}_{\text {org }}$ is present across the same biozonal boundary of TDP Site 36 (Fig. 5a) and indicates coeval changes in the carbon reservoir basin wide. The magnitude of this excursion at TDP Site 36 is $\sim 2 \%$ (Fig. 5a), as opposed to the $\sim 1-1.5 \%$ at Pont d' Issole (Vocontian Basin, SE France) (Jarvis et al., 2011). Also, in contrast to Pont d' Issole, which exhibits positive $\delta^{13} \mathrm{C}_{\text {org }}$ and $\delta{ }^{13} \mathrm{C}_{\text {carb }}$ excursions preceding the $W$. archaeocretacea- $H$. helvetica boundary, identified by many as due to OAE2 (e.g., Jarvis et al., 2006, 2011), we do not see similar positive shifts in TDP Sites 34 or 30 (Jiménez Berrocoso et al., 2012) and only a thin $W$. archaeocretacea interval was cored in TDP Site 36 (Fig. 5a). Note, however, that TDP Sites 21 (lowermost Turonian-Coniacian), 24 (upper Albian-lower Turonian), and 26 (middleupper Cenomanian to lower Turonian) were interpreted to exhibit part of the OAE2 positive $\delta^{13} \mathrm{C}_{\text {org }}$ excursion, which was interrupted by a hiatus (Jiménez Berrocoso et al., 2010). At TDP Sites 30 and 34, other than a lack of positive $\delta^{13} \mathrm{C}_{\text {org }}$ or $\delta^{13} \mathrm{C}_{\text {carb }}$ excursions lower in the $W$. archaeocretacea Zone, relative expansion of the $W$. archaeocretacea Zone (from $\sim 55-85 \mathrm{~m}$ thick) is obvious, as this zone is only $\sim 6 \mathrm{~m}$ thick in Pont d' Issole (Jarvis et al., 2011). The thick $W$. archaeocretacea Zone in Tanzania may be related to either a delayed first appearance of $H$. helvetica or an unusually high sedimentation rate (Jiménez Berrocoso et al., 2010, 2012), whereas the lack of evidence of an OAE2 excursion in such thick sections continues to be a puzzling aspect of the Tanzanian record. It should be noted that many other carbon isotope excursions (see Jarvis et al., 2006) also are apparently absent in Tanzania.

\section{Conclusions}

Six new TDP boreholes drilled in southeastern Tanzania range from the Barremian-middle Albian (TDP $40 \mathrm{~A}$ and 40B) and the Turonian-middle Paleocene (TDP Sites 36, 37, 38 and 39). Results demonstrate predominance of excellent microfossil preservation, as observed elsewhere in the region, and that the Upper Cretaceous succession is relatively thick and continuous. Study of these and previous TDP sites, enables definition of a new unit, the Lindi Fm (upper Albian-Coniacian) at the base of the Kilwa Group. The Lindi Fm (335 m in composite thickness) extends $\sim 120 \mathrm{~km}$ along the Tanzanian margin and was deposited at an outer-shelf to upperslope setting, as inferred from the predominance of clay- and silt-grain lithologies, absence of storm-related sedimentary structures, and consistent presence of open marine fauna and flora (e.g., planktonic microfossils, ammonites). Minor cm-thick sandstones, frequent undisturbed fine lamination, common soft-sediment deformation in the lower-middle Turonian, rare to absent bioturbation, and relatively low $\% \mathrm{CaCO}_{3}$ but high organic carbon (up to $2.6 \%$ in the Turonian) are distinctive features of the Lindi Fm compared to the overlying Nangurukuru Fm.

Good to excellent foraminiferal shell preservation in TDP Sites 36 and 38 (lower-middle Turonian) enhances confidence that geochemical signals in these specimens reflect original values. Relatively poorer shell preservation in TDP Sites 37 (lower Maastrichtian-middle Paleocene), 39 (Coniacian-Santonian) and 40A and 40B (Barremian-middle Albian) reduces the potential for obtaining primary geochemical signatures. However, shell 
preservation in these sites is sufficient for reliable biostratigraphic and paleoecological interpretations. In addition, the 2009 expedition constitutes the first time that a biostratigraphically complete Coniacian-Santonian section (TDP Site 39) and intervals within the Barremian-middle Albian (TDP Sites 40A and 40B) have been recovered in Tanzania and publicly documented, results that will have implications for both regional petroleum geology and regional to global biostratigraphy. Unfortunately, the 2009 TDP sites did not recovered a complete C-T or K-Pg boundary interval. Sandstones barren of microfossils were found below a relatively thick lower-middle Turonian section (TDP Site 36), while a hiatus and/or a faulted contact is present between upper Maastrichtian mudstones and middle Paleocene brecciated carbonates (TDP Site 37).

The bulk sediment isotopic composition from the new sites was consistent with data from previous TDP expeditions and with global evidence for extreme warmth during the Turonian-Santonian (i.e., $\delta^{18} \mathrm{O}_{\text {carb }}$ between $3.5 \%$ and $-5 \%$ in TDP Sites 36,38 and 39 ) relative to the Maastrichtian (i.e., $\delta^{18} \mathrm{O}_{\text {carb }}$ near $-3 \%$ in TDP Site 37 ). Finally, a negative $\delta^{13} \mathrm{C}_{\text {org }}$ excursion, detected across the $W$. archaeocretacea-H. helvetica planktonic foraminiferal zonal boundary of TDP Site 36 correlates with similar shifts found in other lower-middle Turonian TDP boreholes. This excursion occurs close to, but above, the C-T boundary interval and probably resulted from local processes. Without recovery of a complete C-T boundary interval in Tanzania, it is not possible to test whether this negative $\delta^{13} \mathrm{C}_{\text {org }}$ shift was related to the recovery phase of OAE2.

\section{Acknowledgments}

The Tanzania Petroleum Development Corporation and the Tanzanian Commission for Science and Technology are acknowledged for logistical support and permission to carry out this research in the field. We appreciate the generous hospitality and valuable technical assistance of Emma Msaky, Frank Mayagilo and Uyubu. Fieldwork and drilling were funded by a USA National Science Foundation grant to KGM and BTH (EAR 0642993) and a Smithsonian Walcott Fund grant to BTH. JAL was funded by the NERC (Grant NE/G004986/1). TDP Site 37 and TDP Sites 40A and 40B were partially funded by a Royal Society University Research Fellowship held by HKC and SAR, respectively. AJB was partially funded by JAL. Financial support to MRP was provided by MIUR-Prin 2007-2007W9B2WE001 and PUR 2008 of the Università degli Studi di Milano. The PhD program of the Università degli Studi di Milano is acknowledged for funding FF. AJB did the sedimentological and facies analysis. BTH, MRP, HC, FF, HB and AM did the planktonic foraminiferal biostratigraphy. JAL and PRB did the calcareous nannofossil biostratigraphy. IW did the benthic foraminiferal analysis. KGM, SJH, SR and AM carried out the geochemical measurements. All co-authors collaborated on writing the manuscript.

\section{References}

Ando, A., Huber, B.T., Premoli Silva, I., 2013. Paraticinella rohri (Bolli, 1959) as the valid name for the latest Aptian zonal marker species of planktonic foraminifera traditionally called bejaouaensis or eubejaouaensis. Cretaceous Research 45, 275-287.

Balduzzi, A., Msaky, E., Trincianti, E., Manum, S.B., 1992. Mesozoic Karoo and post-Karoo Formations in the Kilwa area, southeastern Tanzania - a stratigraphic study based on palynology, micropalaeontology and well log data from the Kizimbani Well. Journal of African Earth Sciences 15, 405-427.

Berggren, W. A., Kent, D. V., Swisher, I. C. C., and Aubry, M. P., 1995, A Revised Cenozoic Geochronology and Chronostratigraphy, in Berggren, W. A., Kent, D. V., and Hardenbol, J., eds., Geochronology, Time Scales and global stratigraphic correlation: A unified Temporal Framework for an Historical Geology, 54, Society for Sedimentary Geology, Special Publication, 129-212.

Berggren, W.A., Pearson, P.N., 2005. A revised tropical to subtropical Paleogene planktonic foraminiferal zonation. Journal of Foraminiferal Research 35, 279-298.

Bernaola, G., Martin-Rubio, M., Baceta, J.I., 2009. New high resolution calcareous nannofossil analysis across the Danian/Selandian transition at the Zumaia section: comparison with South Tethys and Danish sections. Geologica Acta 7, 7992.

Bolli, H.M., Beckmann, J.P., Saunders, J.B., 1994. Benthic foraminiferal biostratigraphy of the Southern Caribbean region. Cambridge University Press, 408 pp.

Bown, P.R., 2005a. Palaeogene calcareous nannofossils from the Kilwa and Lindi areas of coastal Tanzania (Tanzania Drilling Project 2003-2004). Journal of Nannoplankton Research 27, 21-95.

Bown, P.R., 2005b. Early to mid-Cretaceous calcareous nannoplankton from the northwest Pacific Ocean, Leg 198, Shatsky Rise. Proceedings of the Ocean Drilling Program - Scientific Results 198, 103, ISSN 0884-5883.

Bown, P.R., Lees, J.A., Young, J.R., 2004. Calcareous nannofossil evolution and diversity through time. In: H.R. Thierstein \& J.R. Young (Eds). Coccolithophores: From molecular process to global impact. Springer-Verlag, pp. 481-508. 
Bown, P.R., Dunkley Jones, T. 2006. New Palaeogene calcareous nannofossil taxa from coastal Tanzania: Tanzania Drilling Project Sites 11 to 14. Journal of Nannoplankton Research 28, 17-34.

Bown, P.R., Dunkley Jones, T., Lees, J.A., Pearson, P.N., Randell, R., Coxall, H.K., Mizzi, J., Nicholas, C., Karega, A., Singano, J., Wade, B.S., 2008. A calcareous microfossil Konservat-Lagerstätte from the Paleogene Kilwa Group of coastal Tanzania. GSA Bulletin 120, 3-12.

Bown, P.R., Pearson, P.N., 2009. Calcareous plankton evolution and the Paleocene/Eocene thermal maximum event: New evidence from Tanzania. Marine Micropaleontology 71, 60-70.

Bralower, T.J., Sliter, W.V., Arthur, M.A., Leckie, R.M., Allard, D., Schlanger, S.O., 1993. Dysoxic/anoxic episodes in the Aptian-Albian (Early Cretaceous). Geophysical Monograph 77, 5-37.

Burnett, J.A. (with contributions from Gallagher, L.T. and Hampton, M.J.), 1998. Upper Cretaceous. In: Bown, P.R. (Ed.). Calcareous Nannofossil Biostratigraphy. British Micropalaeontological Society Series, Chapman and Hall/Kluwer Academic Press, pp. 132-199.

Cotton, L., Pearson, P.N., 2011. Extinction of larger benthic foraminifera at the Eocene/Oligocene boundary. Palaeogeography, Palaeoclimatology, Palaeoecology 311, 281-296.

Erba, E., 1994. Nannofossils and superplumes: The early Aptian "nannoconid crisis". Paleoceanography 9, 483-501.

Ernst, G., Schlüter, T., 1989. The Upper Cretaceous of the Kilwa Region, coastal Tanzania. Workshop Geol. Tanzania Rev. Res. Progr., University of Köln, Abstr., Cologne, pp. 1-3.

Ernst, G., Zander, J., 1993. Stratigraphy, facies development, and trace fossils of the Upper Cretaceous of southern Tanzania (Kilwa District). In: Geology and Mineral resources of Somalia and surrounding areas, Inst. Agron. Oltremare Firenze, Relaz. E Monogr. 113, Firenze, pp. 259-278.

Falzoni F., Petrizzo M.R., 2011. Taxonomic overview and evolutionary history of Globotruncanita insignis (Gandolfi, 1955). Journal of Foraminiferal Research 41, 371-383.

Falzoni, F., Petrizzo, M.R., MacLeod, K.G., Huber, B.T., 2013. Santonian-Campanian planktonic foraminifera from Tanzania, Shatsky Rise and Exmouth Plateau: Species depth ecology and paleoceanographic inferences. Marine Micropaleontology $103,15-29$.

Gierlowski-Kordesch, E., Ernst, G., 1987. A flysch trace assemblage from the Upper Cretaceous shelf of Tanzania. In: Matheis, G., Schandelmeier, H. (Eds.). Current Research in African Earth Sciences 217-222.

Gradstein, F.M., Ogg, J.G., Smith, A.G. (Eds.). 2004. A Geologic Time Scale 2004. Cambridge Univ. Press, New York., 589 pp.

Handley, L., Pearson, P.N., McMillan, I.K, Pancost, R.D., 2008. Large terrestrial and marine carbon and hydrogen isotope excursion in a new Paleocene/Eocene boundary section from Tanzania. Earth and Planetary Science Letters 275, 17-25.

Handley, L., O'Halloran, A., Pearson, P.N., Hawkins, E., Nicholas, C.J., Schouten, S., McMillan, I.K., Pancost, R.D., 2012. Changes in the hydrological cycle in tropical East Africa during the Paleocene-Eocene Thermal Maximum. Palaeogeography, Palaeoclimatology, Palaeoecology 329-330, 10-21.

Haynes, S., Huber, B.T., MacLeod, K.G., in press. Evolution and phylogeny of mid-Cretaceous (Albian-Coniacian) biserial planktonic foraminifera.

Herrle, J.O., 2002. Mid-Cretaceous paleoceanographic and paleoclimatologic implications on black shale formation of the Vocontian Basin and Atlantic. Evidence from calcareous nannofossils and stable isotopes. Tub. Mikropalaeontol. Mitt. 27, $114 \mathrm{pp}$.

Huber, B.T., MacLeod, K.G., Tur, N.A., 2008. Chronostratigraphic framework for Upper Campanian-Maastrichtian sediments on the Blake Nose (subtropical North Atlantic). Journal of Foraminiferal Research 38, 162-182.

Huber, B.T., Leckie, R.M., 2011. Planktic foraminiferal species turnover across deep-sea Aptian/Albian boundary section. Journal of Foraminiferal Research, 41, 53-95 pp.

Huber, B.T., Petrizzo, M.R., 2014. Evolution and taxonomic study of the Cretaceous planktonic foraminifer genus Helvetoglobotruncana Reiss, 1957. The Journal of Foraminiferal Research 44, 40-57.

Jarvis, I., Gale, A.S., Jenkyns, H.C., Pearce, M.A., 2006. Secular variation in Late Cretaceous carbon isotopes: a new $\delta^{13}$ C carbonate reference curve for the Cenomanian-Campanian (99.6-70.6 Ma). Geological Magazine 143, 561-608.

Jarvis, I., Lignum, J.S., Gröcke, D.R., Jenkyns, H.C., Pearce, M.A., 2011. Black shale deposition, atmospheric $\mathrm{CO}_{2}$ drawdown, and cooling during the Cenomanian-Turonian Oceanic Anoxic Event. Paleoceanography 26, PA3201.

Jenkyns, H. C., 2010. Geochemistry of oceanic anoxic events. Geochem. Geophys. Geosyst. 11, Q03004.

Jiménez Berrocoso, Á., MacLeod, K.G., Huber, B.T., Lees, J.A., Wendler, I., Bown, P.R., Mweneinda, A.K., Isaza Londoño, C., Singano, J., 2010. Lithostratigraphy, biostratigraphy and chemostratigraphy of Upper Cretaceous sediments from southern Tanzania: Tanzania drilling project sites 21-26. Journal of African Earth Sciences 57, 47-69.

Jiménez Berrocoso, Á., Huber, B.T., MacLeod, K.G., Petrizzo, M.R., Lees, J.A, Wendler, I., Coxall, H., Mweneinda, A.K., Falzoni, F., Birch, H., Singano, J.M., Haynes, S., Cotton, L., Wendler, J., Bown, P.R., Robinson, S.A., Gould, J., 2012. Lithostratigraphy, biostratigraphy and chemostratigraphy of Upper Cretaceous and Paleogene sediments from southern Tanzania: Tanzania Drilling Project Sites 27-35. Journal of African Earth Sciences 70, 36-57.

Kapilima, S., 2003. Tectonic sedimentary evolution of the coastal basin of Tanzania during the Mesozoic times. Tanzania Journal of Sciencies 29, 1-16.

Kejato, H., 2003. The geology and petroleum potential of Tanzania. Tanzania Petroleum Development Corporation, Dar-esSalaam.

Kennedy, W.J., Gale, A.S., Bown, P.R., Caron, M., Davey, R.J., Grocke, D., Wray, D.S., 2000. Integrated stratigraphy across the Aptian-Albian boundary in the Marnes Bleues, at the Col de Pre-Guittard, Arnayon (Drome), and at Tartonne (Alpes de 
Haute Provence), France: a candidate Global Boundary Stratotype Section and Boundary Point for the base of the Albian Stage. Cretaceous Research 21, 591-720.

Kent, P.E., Hunt, J.A., Johnstone, D.W., 1971. The Geology and Geophysics of Coastal Tanzania. Institute of Geological Sciences Geophysical Paper No.6, 1-101.HMSO, London.

Key, R.M., Smith, R.A., Smelor, M., Sæther, O.M., Thorsnes, T., Powell, J.H., Njange, F., Zandamela, E.B., 2008. Revised lithostratigraphy of the Mesozoic-Cenozoic succession of the onshore Rovuma Basin, northern coastal Mozambique. South African Journal of Geology 111, 89-108.

Lees, J.A., 2007. New and rarely reported calcareous nannofossils from the Late Cretaceous of coastal Tanzania: outcrop samples and Tanzania Drilling Project Sites 5, 9 and 15. Journal of Nannoplankton Research 29, 39-65.

Lees, J.A., Bown, P.R., in review. Novel Cretaceous calcareous nannofossil taxa from the Turonian of Tanzania. Journal of Nannoplankton Research.

MacLeod, K.G., Huber, B.T., Jiménez Berrocoso, Á., Wendler, I. 2013. A stable and hot Turonian without glacial $\delta^{18} \mathrm{O}$ excursions is indicated by exquisitely preserved Tanzanian foraminifera. Geology 41, 1083-1086.

Martini, E., 1971. Standard Tertiary and Quaternary calcareous nannoplankton zonation. In: A. Farinacci (Ed.). Proceedings of the Second Planktonic Conference Roma 1970. Edizioni Tecnoscienza, Rome 2, 739-785.

Mpanda, S., 1997. Geological development of the East African coastal basin of Tanzania. Stockholm Contributions in Geology $45,1-127$.

Moore, W.R., McBeath, D.M., Linton, R.E., Terris, A.P., Stoneley, R., 1963. Geological Survey of Tanganyika Quarter Degree Sheet 256 \& 256E. 1:125 000 Kilwa. First ed. Geological Survey Division, Dodoma.

Nicholas, C.J., Pearson, P.N., Bown, P.R., Dunkley Jones, T., Huber, B.T., Karega, A., Lees, J.A., McMillan, I.K., O’Halloran, A., Singano, J., Wade, B.S., 2006. Stratigraphy and sedimentology of the Upper Cretaceous to Paleogene Kilwa Group, southern coastal Tanzania. Journal of African Earth Sciences 45, 431-466.

Nicholas, C.J., Pearson, P.N., McMillan, I.K., Ditchfield, P.W., Singano, J.S., 2007. Structural evolution of coastal Tanzania since the Jurassic. Journal of African Earth Sciences 48, 273-297.

Pearson, P.N., Ditchfield, P.W., Singano, J., Harcourt-Brown, K.G., Nicholas, C.J., Olsson, R.K., Shackleton, N.J., Hall, M.A., 2001. Warm tropical sea surface temperatures in the Late Cretaceous and Eocene epochs. Nature 413, 481-487.

Pearson, P.N., Nicholas, C.J., Singano, J.M., Bown, P.R., Coxall, H.K., van Dongen, B.E., Huber, B.T., Karega, A., Lees, J.A., Msaky, E., Pancost, R.D., Pearson, M., Roberts, A.P., 2004. Paleogene and Cretaceous sediment cores from the Kilwa and Lindi areas of coastal Tanzania: Tanzania Drilling Project Sites 1-5. Journal of African Earth Sciences 39, 25-62.

Pearson, P.N., Nicholas, C.J., Singano, J.M., Bown, P.R., Coxall, H.K., van Dongen, B.E., Huber, B.T., Karega, A., Lees, J.A., MacLeod, K., McMillan, I.K., Pancost, R.D., Pearson, M., Msaky, E., 2006. Further Paleogene and Cretaceous sediment cores from the Kilwa area of coastal Tanzania: Tanzania Drilling Project Sites 6-10. Journal of African Earth Sciences 45, 279-317.

Pearson, P.N., van Dongen, B.E., Nicholas, C.J., Pancost, R.D., Schouten, S., Singano, J.M., and Wade, B.S., 2007. Stable warm tropical climate through the Eocene epoch. Geology, 35, 211-214.

Pearson, P.N., McMillan, I.K., Singano, J.M., Wade, B.S., Jones, T.D., Coxall, H.K., Bown, P.R., Lear, C.H., 2008. Extinction and environmental change across the Eocene-Oligocene boundary in Tanzania. Geology 36, 179-182.

Pérez Rodríguez, I., Lees, J.A., Larrasoaña, J.C., Arz, J.A., Arenillas, I., 2012. Planktonic foraminiferal and calcareous nannofossil biostratigraphy and magnetostratigraphy of the uppermost Campanian and Maastrichtian at Zumaia, northern Spain. Cretaceous Research 37, 100-126.

Petrizzo, M.R., Falzoni, F., Premoli Silva, I., 2011. Identification of the base of the lower-to-middle Campanian Globotruncana ventricosa Zone: comments on reliability and global correlations. Cretaceous Research 32, 387-405.

Petrizzo M.R., Huber B.T., Gale A.S., Barchetta A., Jenkyns H.C., 2012. Abrupt planktic foraminiferal turnover across the Niveau Kilian at Col de Pré-Guittard (Vocontian Basin, southeast France): new criteria for defining the Aptian/Albian boundary. Newsletters on Stratigraphy 45, 55-74.

Petrizzo M.R., Huber B.T., Gale A.S., Barchetta A., Jenkyns H.C., 2013. Erratum: Abrupt planktic foraminiferal turnover across the Niveau Kilian at Col de Pré-Guittard (Vocontian Basin, southeast France): new criteria for defining the Aptian/Albian boundary. Newsletters on Stratigraphy 46, 93-93.

Robaszynski, F., Caron, M., 1995. Foraminifères planktoniques du Crétacé: commentaire de la zonation Europe-Méditerranée. Société géologique de France 166, 681-692.

Salman, G., Abdula, I., 1995. Development of the Mozambique and Ruvuma sedimentary basins, offshore Mozambique. Sedimentary Geology 96, 7-41.

Sliter, W.V., 1989. Biostratigraphic zonation for Cretaceous planktonic foraminifers examined in thin section. Journal of Foraminiferal Research 19, 1-19.

Roth, P.H., 1978. Cretaceous nannoplankton biostratigraphy and oceanography of the northwestern Atlantic Ocean. Initial Reports of the DSDP 44, 731-760.

Schlüter, T., 1997. Geology of East Africa. Borntraeger, Stuttgart, 512 pp.

Stewart, D.R.M., Pearson, P.N., Ditchfield, P.W., Singano, J.M., 2004. Miocene tropical Indian Ocean temperatures: evidence from three exceptionally preserved foraminiferal assemblages in Tanzania. Journal of African Earth Sciences 40, 173-190.

Thomas, M., 2007. Petroleum potential of Permian rift basins in East Africa. The Selous Basin - Tanzania (Karroo PermoTriassic): Dominion Petroleum presentation, $24 \mathrm{pp}$. 
van Dongen, B.E., Talbot, H.M., Schouten, S., Pearson, P.N., Pancost, R.D., 2006. Well preserved Palaeogene and Cretaceous biomarkers from the Kilwa area, Tanzania. Organic Geochemistry 37, 539-557.

Varol, O., 1998. Paleogene. In: Bown, P.R. (Ed.). Calcareous Nannofossil Biostratigraphy. British Micropalaeontological Society Series, Chapman and Hall/Kluwer Academic Press, pp. 200-224.

Veeken, P.C.H., Titov, K.V., 1996. Gravity modelling along a seismic line across the Mandawa basin, southeastern Tanzania. Journal of African Earth Sciences 22, 207-217.

Wade, B.S., Pearson, P.N., 2008. Planktonic foraminiferal turnover, diversity fluctuations and geochemical signals across the Eocene/Oligocene boundary in Tanzania. Marine Micropaleontology 68, 244-255.

Wade, B.S., Pearson, P.N., Berggren, W.A., and Pälike, H., 2011, Review and revision of Cenozoic tropical planktonic foraminiferal biostratigraphy and calibration to the geomagnetic polarity and astronomical time scale: Earth-Science Reviews $104,111-142$.

Williams, L., 2009. The Songo Songo gas field, Tanzania: increasing reserves and expanding gas distribution. $8^{\text {th }}$ Petroleum Exploration Society of GB/Houston Geological Society Conference on African Exploration and Production.

Wendler, I., Huber, B.T., MacLeod, K.G., Wendler, J.E., 2011. Early evolutionary history of Tubulogenerina and Colomia: New species from exceptionally preserved Turonian sediments from East Africa. Journal of Foraminiferal Research 41, 384-400.

Wendler, I., Huber, B.T., MacLeod, K.G., Wendler, J.E., 2013. Stable oxygen and carbon isotope systematics of exquisitely preserved Turonian foraminifera from Tanzania-Understanding isotopic signatures in fossils. Marine Micropaleontology 102, 1-33.

Wendler, J., Bown, P.R., 2013. Exceptionally well-preserved Cretaceous microfossils reveal new biomineralization styles. Nature Communications 4, doi:10.1038/ncomms3052.

\section{Table and Figure captions}

Table 1. Maximum, minimum and mean depths $(\mathrm{m})$ of core samples with or without foraminiferal First Appearance Datum (FAD) and Last Appearance Datum (LAD), along with estimated ages according to Robaszynski and Caron (1995), Gradstein et al. (2004), Berggren and Pearson (2005), Huber et al. (2008) and Petrizzo et al. (2011). Lowest and Highest Occurrences (LOs and HOs) represent observations of age-diagnostic species, the stratigraphic ranges of which are truncated in the TDP boreholes due to unconformities or barren intervals. The range truncation indicates that age estimates for the LOs and HOs are less or greater than the FAD and LAD ages, respectively. ${ }^{a}$ Gradstein et al. (2004); ${ }^{b}$ predates age of Zone P4b used by Berggren and Pearson (2005); ${ }^{\circ}$ Berggren and Pearson (2005); ${ }^{\mathrm{d}}$ Huber et al. (2008); ${ }^{\mathrm{e}}$ predates Albian-Cenomanian boundary age of Gradstein et al. (2004); ${ }^{\mathrm{f}}$ Robaszynski and Caron, 1995.

Table 2. Different stratigraphic units of the Kilwa Group, along with the main and secondary lithological characteristics (Nicholas et al., 2006; this study). ${ }^{a}$ Color of weathered sediments; ${ }^{b}$ color of fresh sediments.

Table 3. Facies association of the Lindi Fm (lithofacies 2, 3 and 4) versus other lithofacies defined during the 2006 to 2009 TDP field seasons (lithofacies 1 and 5) (Jiménez Berrocoso et al., 2010, 2012).

Figure 1. Location of Cretaceous and Paleogene-Neogene sediments between Kilwa and Lindi in southeastern Tanzania.

Figure 2. Comparison of different stratigraphic units proposed for the Upper Cretaceous-Paleogene in southeastern Tanzania and northeastern Mozambique (onshore and offshore) according to (1) Nicholas et al. (2006) and this study, (2) Mpanda (1997), Kapilima (2003), Kejato (2003) and Thomas (2007), and (3) Key et al. (2008). Note position of the Lindi Fm in the upper Albian to Coniacian.

Figure 3. Stratigraphic extent of the TDP sites drilled prior to 2007 and in 2007 to 2009, together with main stratigraphic units.

Figure. 4a. Simplified geological map of the Lindi region (modified from Nicholas et al., 2007; Jiménez Berrocoso et al., 2010), showing distribution of the TDP sites. See Fig. $4 \mathrm{~b}$ for map legend.

Figure. 4b. Map legend for Fig. 4a.

Figure 5a. Integrated lithostratigraphy, planktonic foraminiferal and calcareous nannofossil biostratigraphy and chemostratigraphy of TDP Site 36 . Lower limit of weathering is at the top of core 13 . The black arrow in the lower part of the $\delta^{13} \mathrm{C}_{\text {org }}$ profile denotes the decreasing isotopic trend across the W. archaeocretacea-H. helvetica boundary. Unexamined interval: unexam. Symbols are given in Fig. 5 b.

Figure. 5b. Key to logs of Figs. 5a, 8a-b, 10, 12, 14a and 14b. 
Figure 6. Core photographs of TDP Site 36 (lower-middle Turonian). (a) $\mathrm{mm}$ - to $\mathrm{cm}$-thick interbedded, sandy siltstones and claystones in core TDP36/29. (b) cm-thick layer of massive, lithified siltstones with gradational bottom contact in core TDP36/15. (c) Slightly inclined lamination in core TDP36/24. (d) Highly disturbed lamination in core TDP36/13. (e) Undulated contact between the mudstones of the Lindi Fm and the underlying barren sandstones in core TDP36/43. (f) Loaded surface within the sandstone interval underlying the Lindi Fm in core TDP36/46.

Figure 7. Simplified geological map of the Kilwa peninsula, modified from Nicholas et al. (2007). See Fig. 4b for map legend.

Figure 8a. Integrated lithostratigraphy, planktonic foraminiferal and calcareous nannofossil biostratigraphy and chemostratigraphy of TDP Site 37. Lower limit of weathering is in core 11. Symbols are given in Fig. 5b.

Figure 8b. Lower part of TDP Site 37 (see upper part in Fig. 8a). Symbols are given in Fig. 5b.

Figure 9. Core photographs of TDP Site 37 (middle Paleocene-lower Maastrichtian). (a) Bioclastic limestones with vuggy porosity in core TDP37/2. (b) Brecciated limestones in core TDP Site 37/8. (c) and (d) poorly-sorted limestone clasts and sandy matrix of cores TDP Site 37/11 and 12, respectively; white rectangle in (c) represents position of washed-residue sample for biostratigraphy. (e) and (f) olive gray, monotonous, calcareous claystones in cores TDP37/37 and 50 .

Figure 10. Integrated lithostratigraphy, planktonic foraminiferal and calcareous nannofossil biostratigraphy, and chemostratigraphy of TDP Site 38. Lower limit of weathering is at the top of core 8. Unexamined interval: unexa. Symbols are given in Fig. 5b.

Figure 11. Core photographs of TDP Site 38 (lower-middle Turonian). (a) Weathered claystones in core TDP38/5; note calcite vein fracture towards the middle of the picture. (b) Weakly-bedded claystones in core TDP38/9.

Figure 12. Integrated lithostratigraphy, planktonic foraminiferal and calcareous nannofossil biostratigraphy and chemostratigraphy of TDP Site 39. Lower limit of weathering is at the top of core 14. Symbols are given in Fig. $5 \mathrm{~b}$.

Figure 13. Core photographs of TDP Site 39 (Coniacian to Santonian). (a) Dark greenish gray, massive, calcareous, clayey siltstones in core TDP39/14; note the mm-thick layers of carbonated-cemented siltstones on the left-hand side of the picture. (b) and (c) Examples of dark gray intervals with abundant bioturbation (Chondrites) alternating with lighter intervals with rare bioturbation in cores TDP39/18 and 20. (d) Detailed view of the white rectangle in (c), with abundant bioturbation in the darker interval of the core compared to the lighter part. (e) and (f) Carbonatecemented siltstone layers (mm- to cm-thick and white coloured) in core TDP39/34; note in (f) the ripple-like structure at the top of a carbonate-cemented layer.

Figure 14. Integrated lithostratigraphy, planktonic foraminiferal and calcareous nannofossil biostratigraphy and chemostratigraphy of TDP Site 40A (a) and 40B (b). Lower limit of weathering is in core 13 of both sites. Symbols are given in Fig. 5b.

Figure 15. Core photographs of TDP Site 40A and 40B (Barremian to middle Albian). (a) Greenish black, massive to weakly bedded, calcareous siltstones in core TDP40A/11. (b) Conglomeratic, calcareous sandstones with mudclasts (between $0.87 \mathrm{~cm}$ and $0.92 \mathrm{~cm}$ ) in core TDP40A/9 (see also Fig. 16b). (c) Greenish black, calcareous claystones with moderate to abundant bioturbation (see Fig. 16c) in core TDP40A/12. (d) Greenish black, massive, calcareous claystones, with pyrite nodules in core TDP40A/17. (e) Polygenic conglomerates in core TDP40A/23. (f) Grayish black, massive to weakly-bedded, calcareous sandstones in core TDP40A/28.

Figure 16. Thin-section views (in normal light) of the lithologies cored at TDP Site 40A (Barremian to middle Albian). (a) Calcareous siltstone of core TDP40A/10 showing abundant angular to sub-rounded quartz (white grains) and minor disseminated pyrite (dark brown to black grains) within a carbonate matrix. (b) Calcareous sandstone in core TDP40A/8 (see Fig. 15b), with abundant rounded to sub-rounded quartz (white grains) and minor bioclasts (Bc). (c) Calcareous claystone in core TDP40A/13 showing evidence of bioturbation (e.g., light circular shape surrounded by darker carbonate matrix in the left hand side of the picture; see Fig. 15c). (d) Abundant angular to sub-angular quartz (white grains) and minor bioclasts (Bc) of the conglomerates in core TDP40A/23 (see Fig. 15e). 
Figure 17. Selected core photographs that show (a) and (b) transition between the Nangurukuru Fm (calcareous claystones, core TDP39/27, D. asymetrica Zone) into the Lindi Fm (laminated mudstones, core TDP39/40, D. concavata Zone), (c) the Lindi Fm (laminated mudstones, core TDP36/11, H. helvetica Zone), (d) the oldest bottom of the Lindi Fm (dark gray claystones, core TDP24/27, P. buxtorfi Zone), and (e) sandstones and claystones underlying the Lindi Fm (core TDP24/28, P. buxtorfi Zone).

Figure 18. Correlation of TDP Sites 24, 22, 31 and 39 showing the entire stratigraphy of the Lindi Fm (shaded gray) from the upper Albian P. buxtorfi Zone (TDP Site 24) to the Coniacian D. concavata Zone (TDP Site 39).

Figure 19. Cross-plot of $\% \mathrm{CaCO}_{3}$ versus $\% \mathrm{TOC}$ (total organic carbon) from the Upper Cretaceous TDP sites. Note generally lower $\% \mathrm{CaCO}_{3}$ and higher \%TOC in the Lindi Fm than in the Nangurukuru Fm.

Figure 20. Bottom of the Lindi Fm at TDP Sites 33, 36, 24 and 21 (see geographic distribution of these sites in Fig. 4a). Note conformable bottom contact of the Lindi Fm at TDP Site 24 versus interpreted faulted bottom contacts at TDP Sites 33, 36, and 21 (see detailed explanations in the main text). 
1) Onshore Tanzania (Mandawa \& Rovuma)

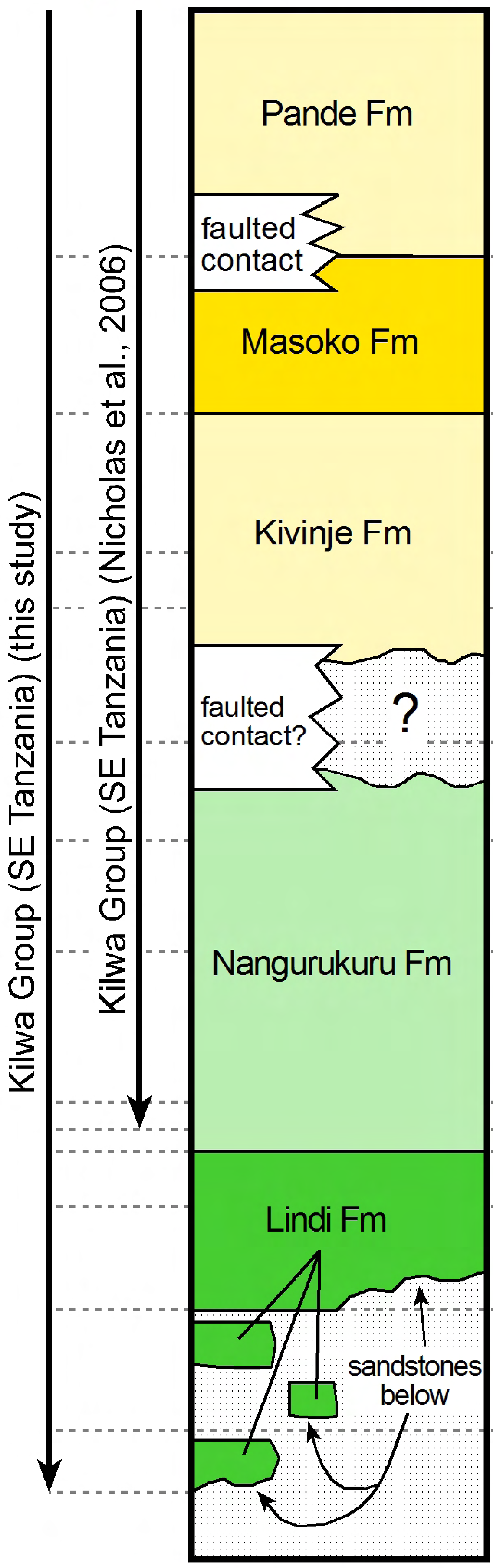

see Table 2 for a description of these units

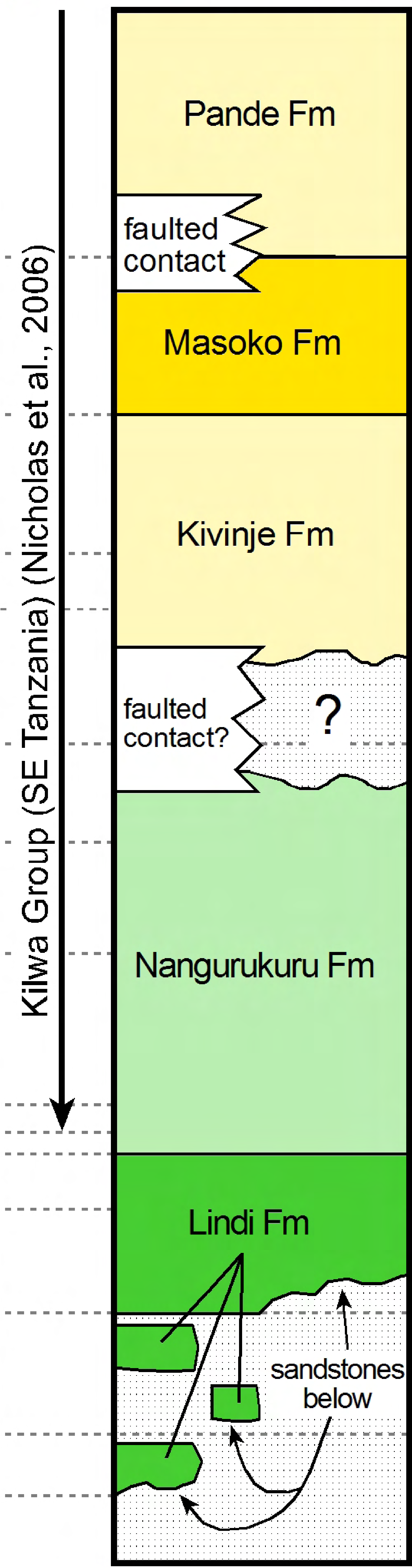

2) On-/offshore

Tanzania (Mandawa \& Rovuma)

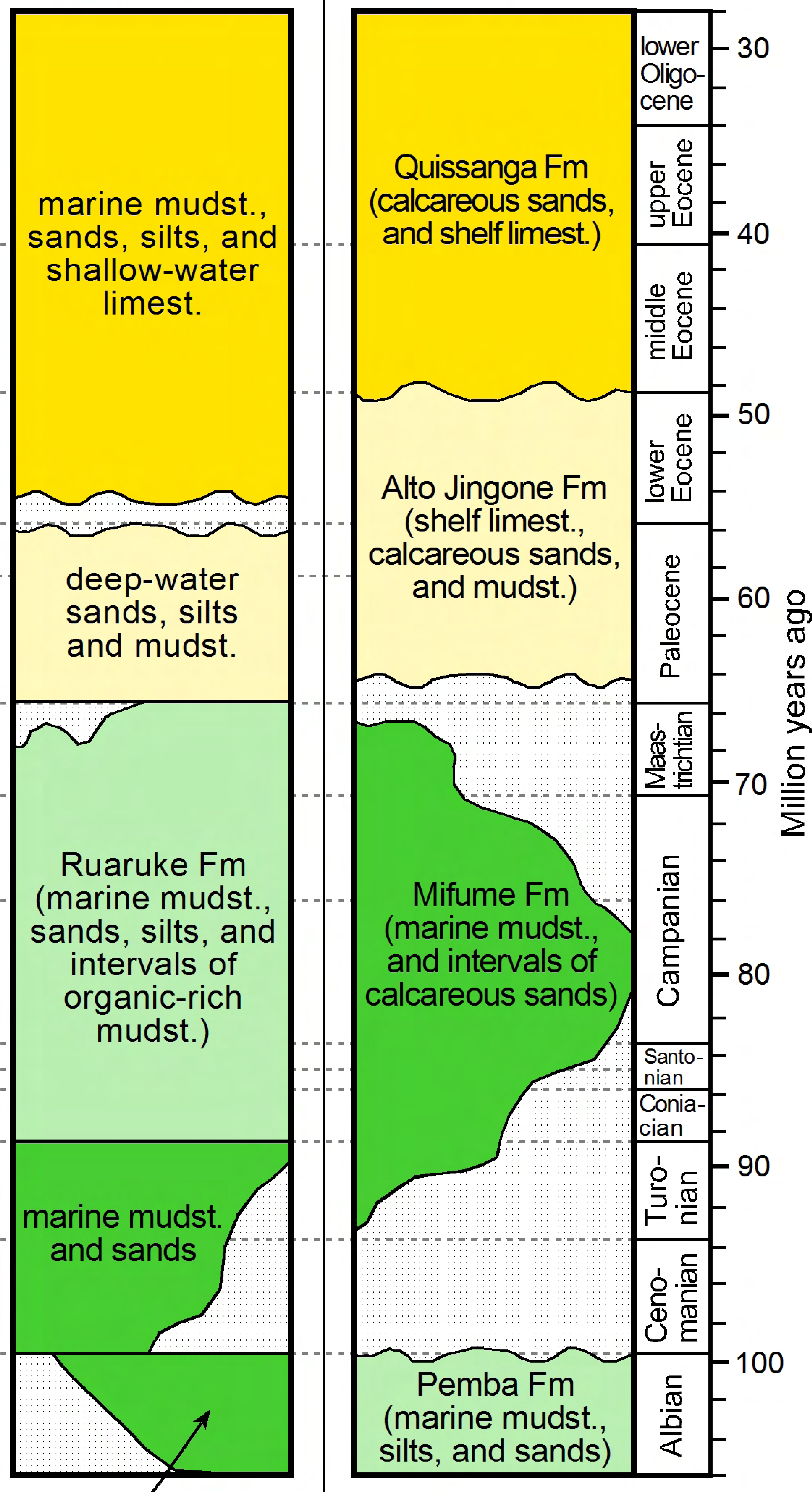

3) On-/offshore Mozambique (Rovuma)

(Rovuma) ower -30 Oligo-

Quissanga Fm (calcareous sands, marine mudst., 
$\because \because$ Miocene or younger

sandy limestones

Miocene clays

\section{Pande Fm}

P14a-P21 (E13 - O4) (upper Eocene

MIm - lower Oligocene)

\section{Masoko Fm}

P10 - P13 (E8 - E12) (middle Eocene)

\section{Lindi Fm}

P4 - P5 (P4 - E2) (upper Paleocene -

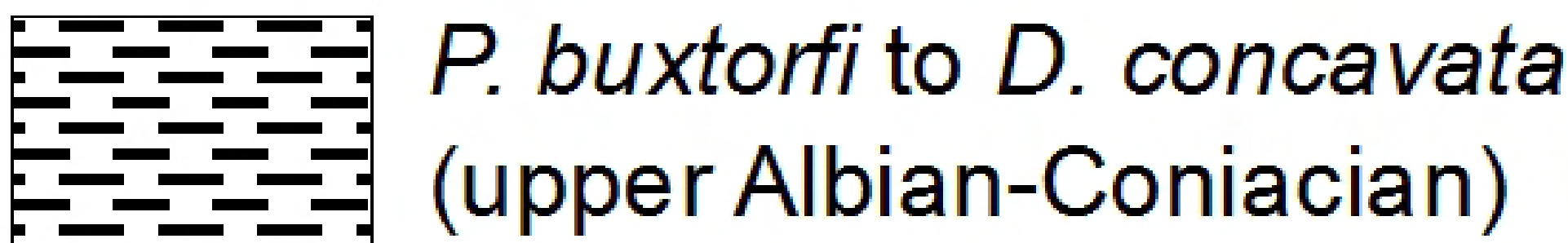
lower Eocene) 


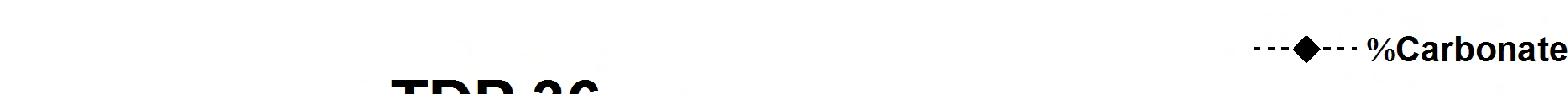

Nannos Forams

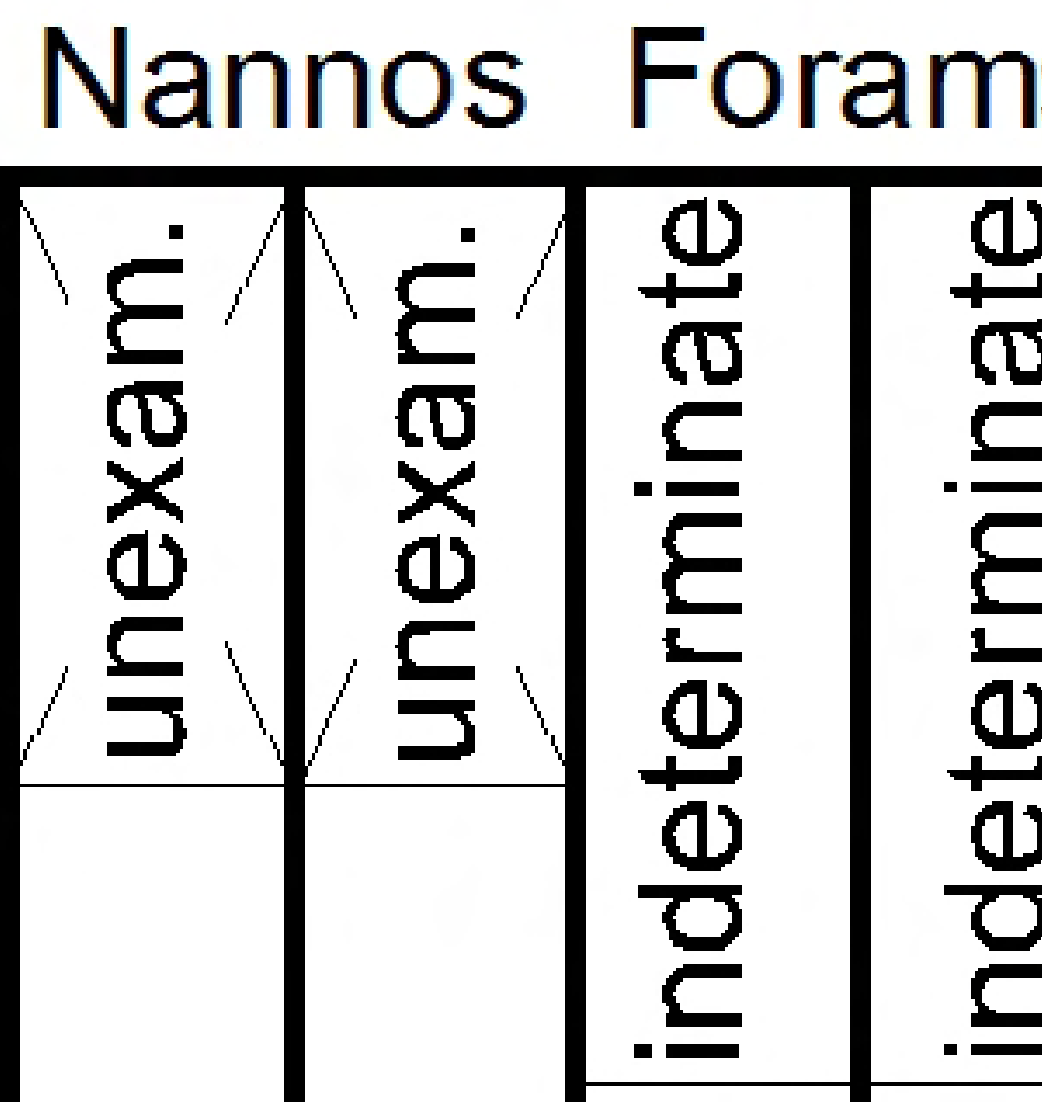

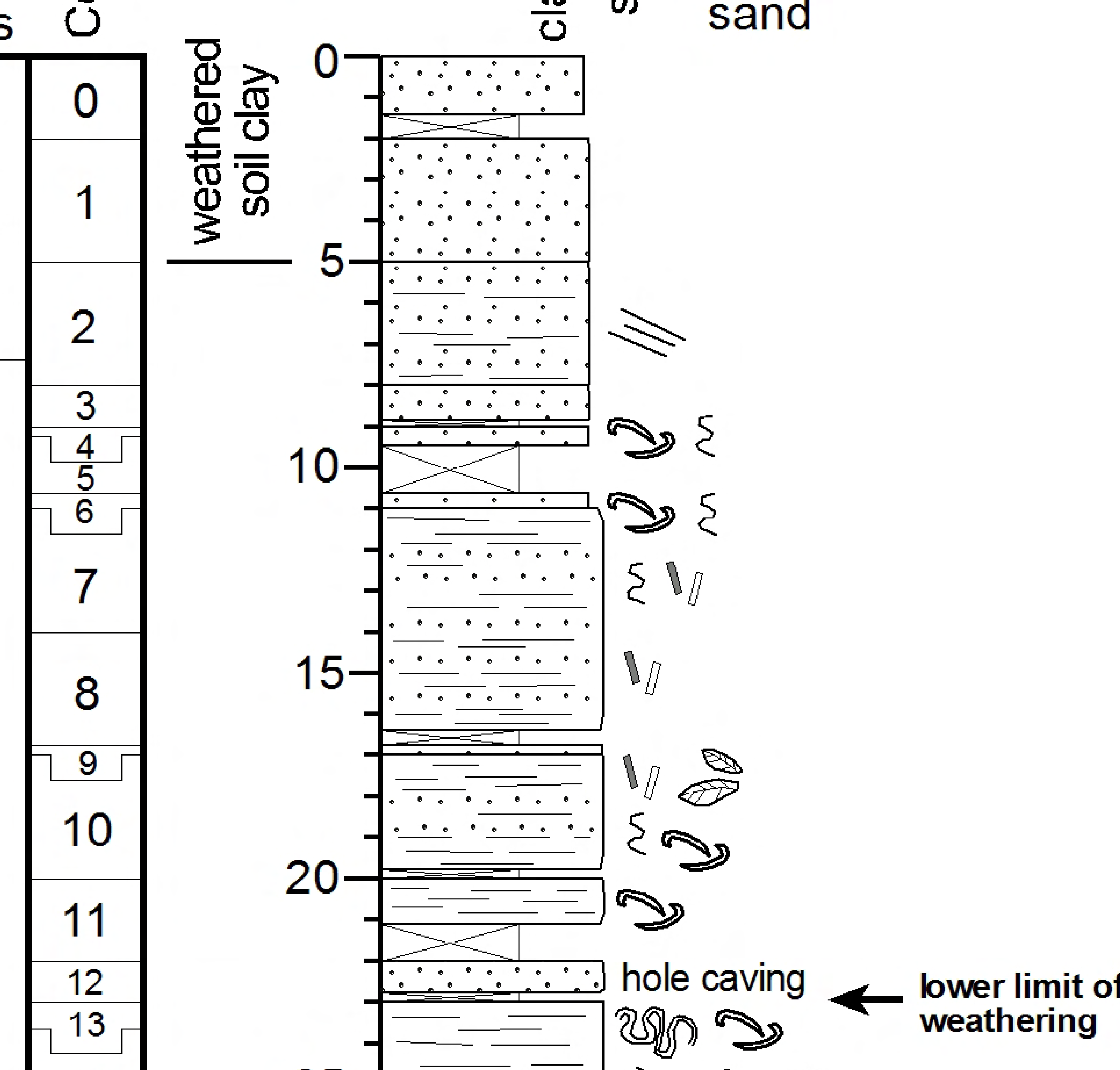

$25 \overline{\bar{E}} \approx$ =

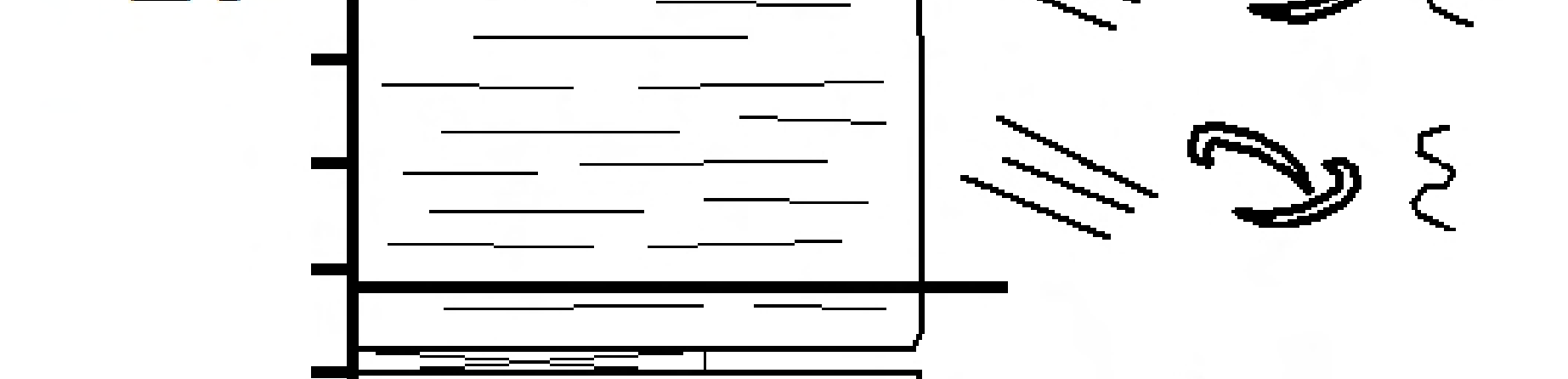

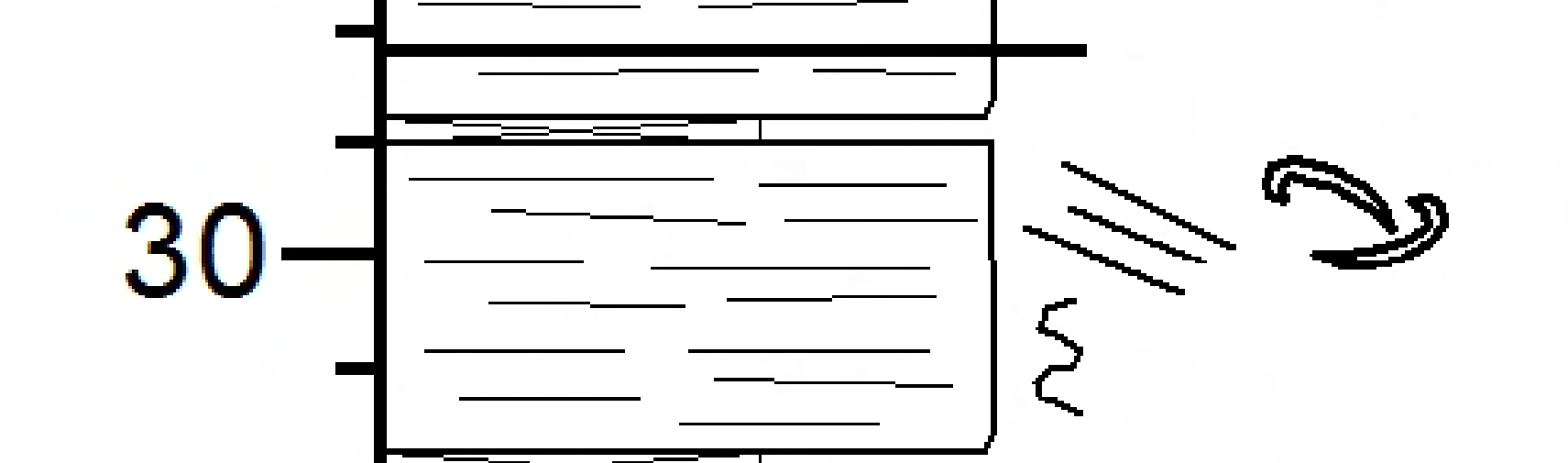

$\approx$
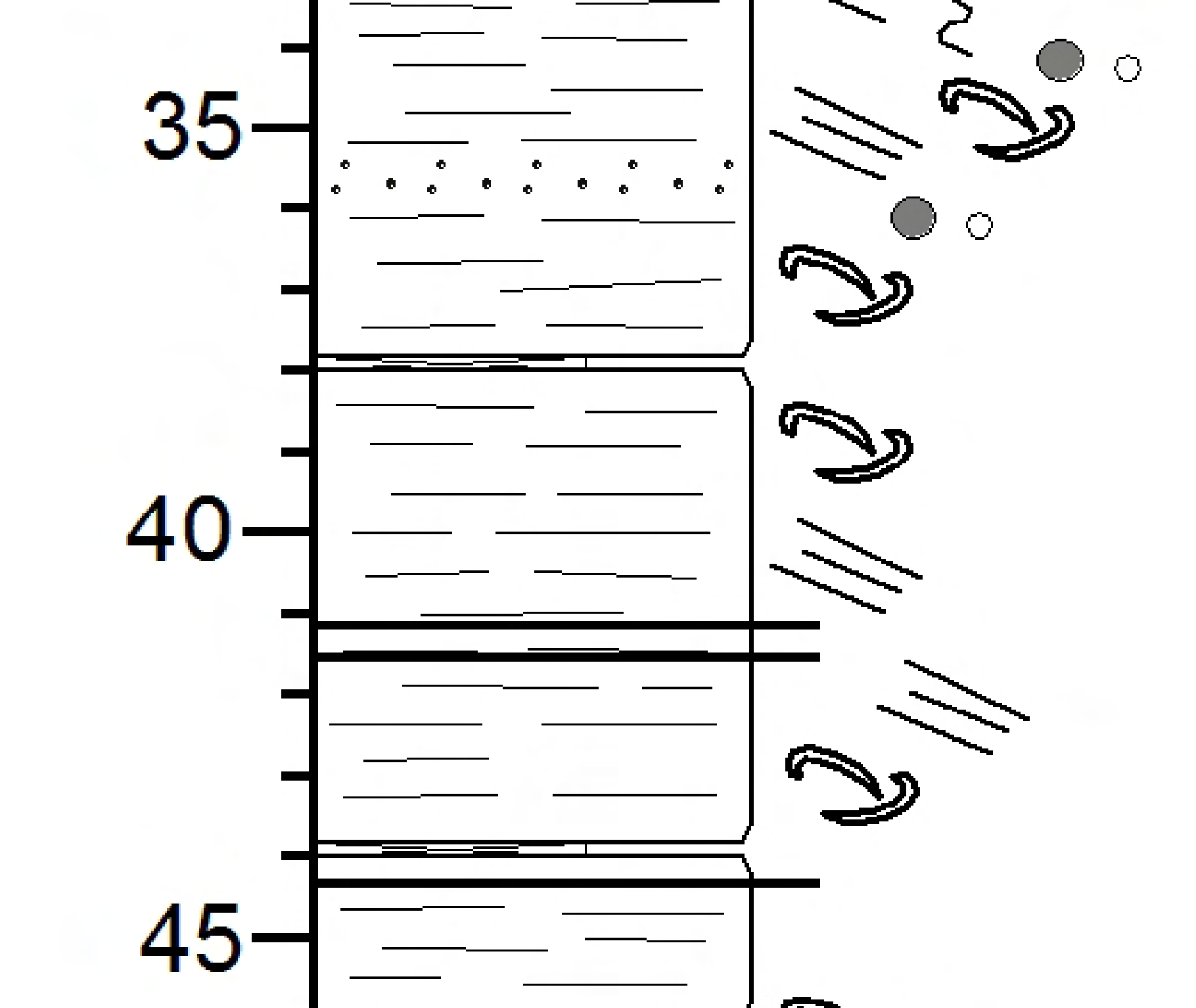

$\%$ Carbonate

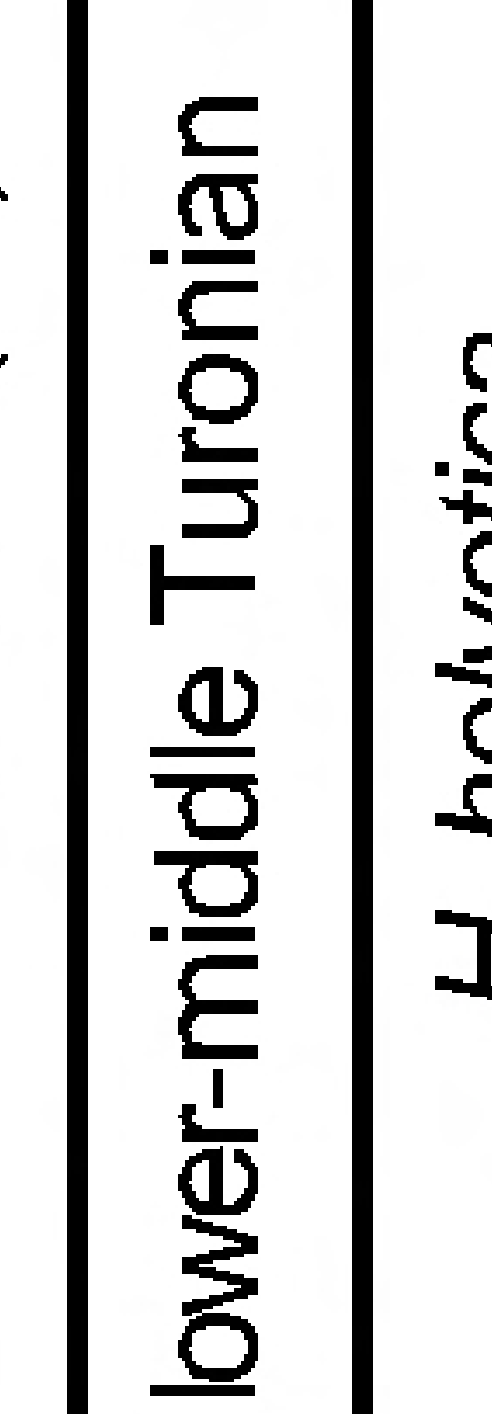

这

$\stackrel{F}{-}$

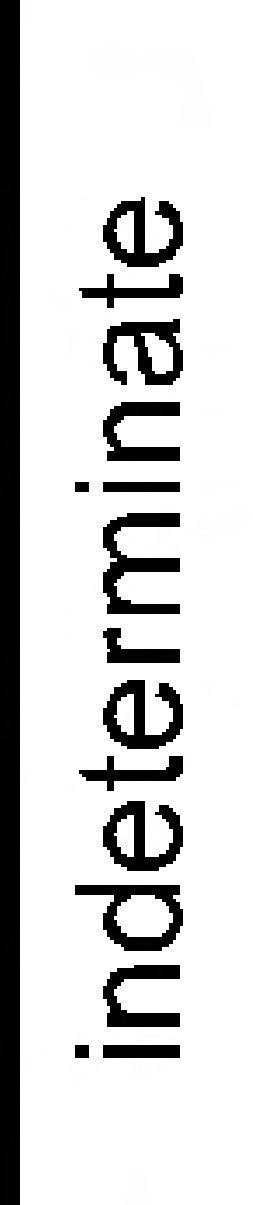

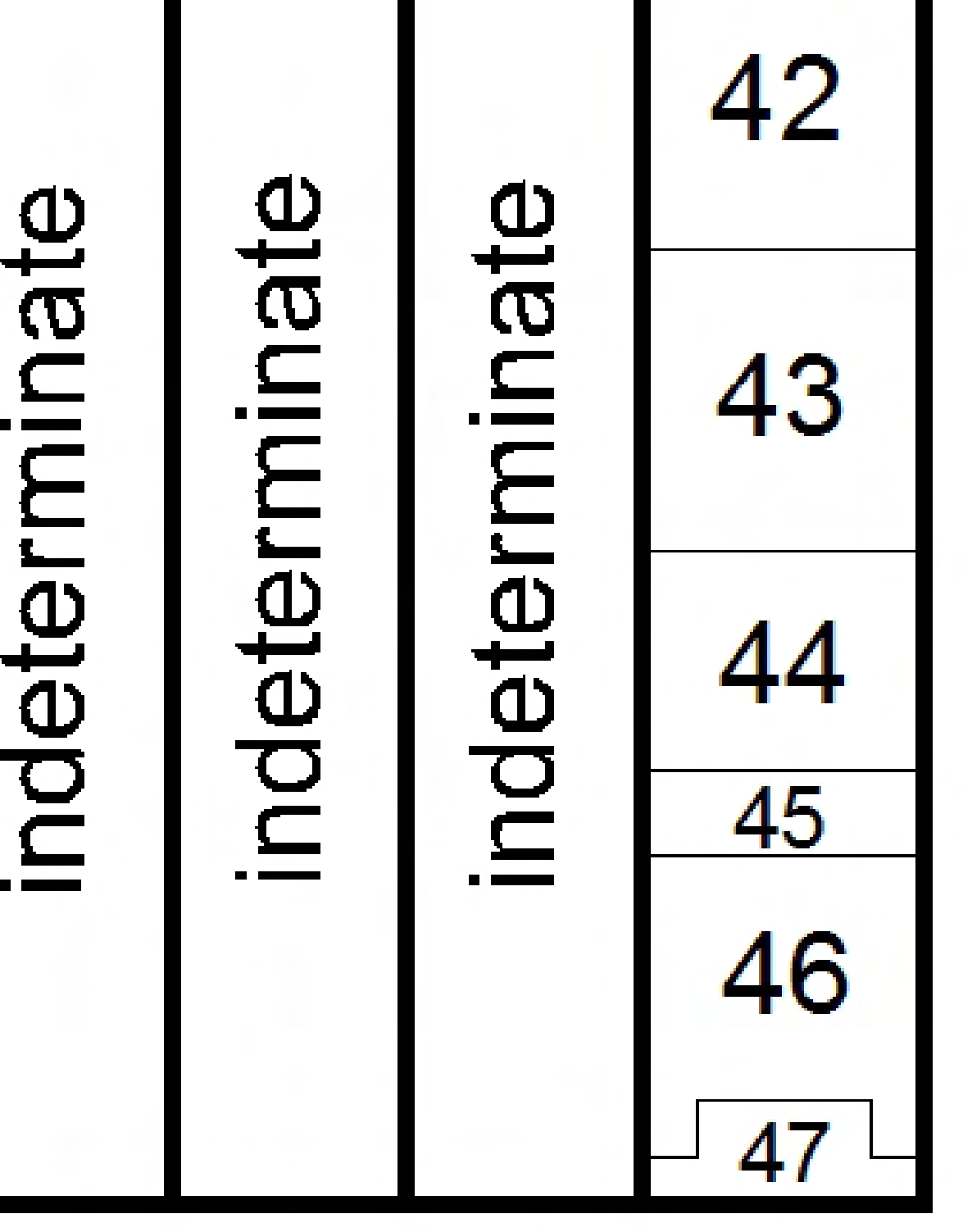

0
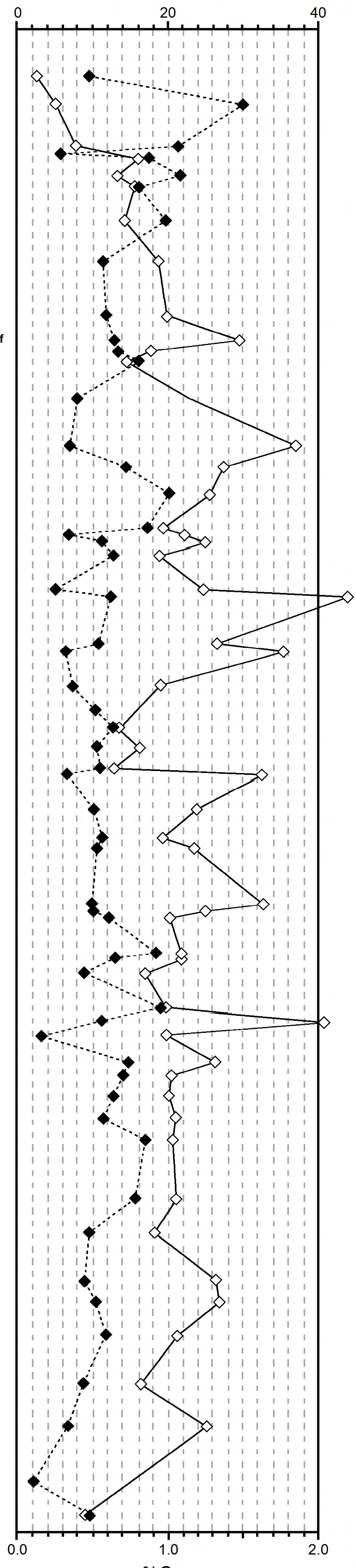

$\% \mathrm{C}_{\text {org }}$ $\delta^{13} \mathrm{C}_{\text {carb }}-\delta^{18} \mathrm{O}_{\text {carb }}$

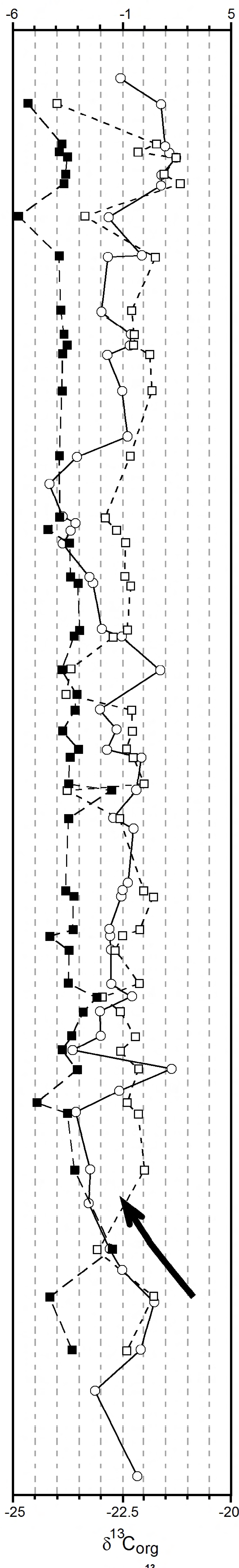



lamination
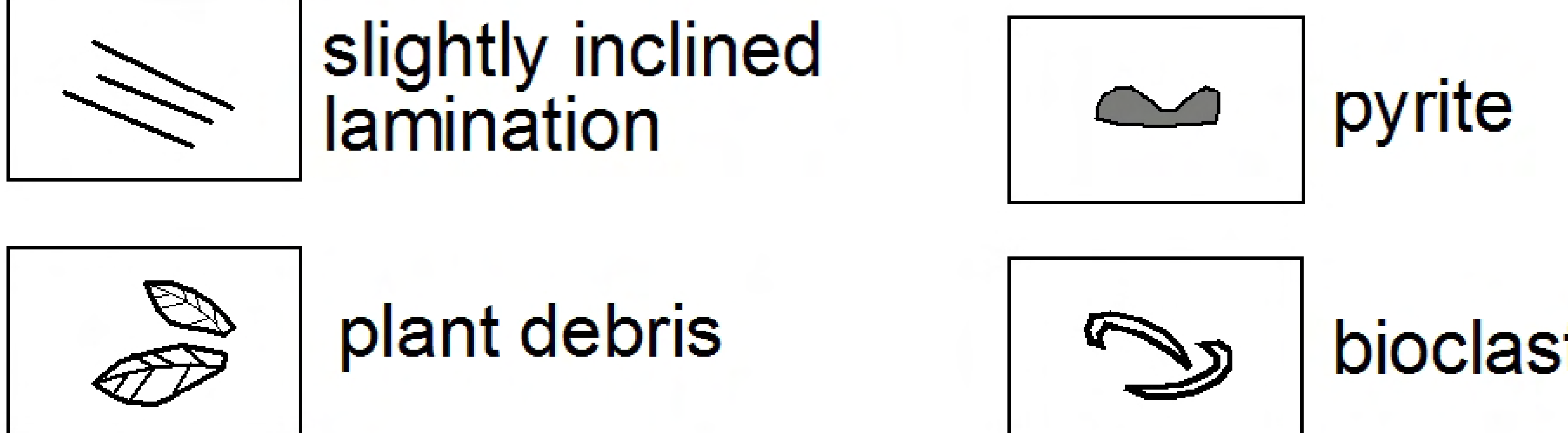

plant debris

$\sum$ bioturbation

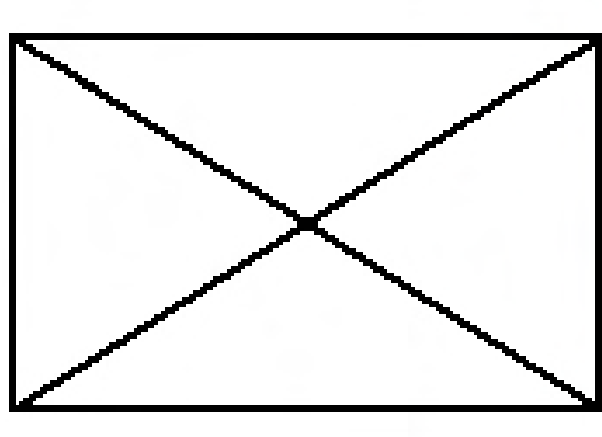

unrecovered interval

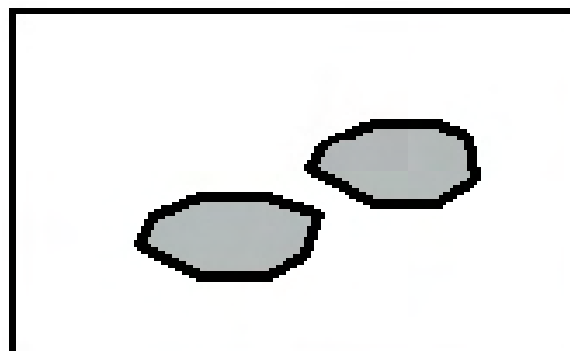

dissolution vugs

vein fractures
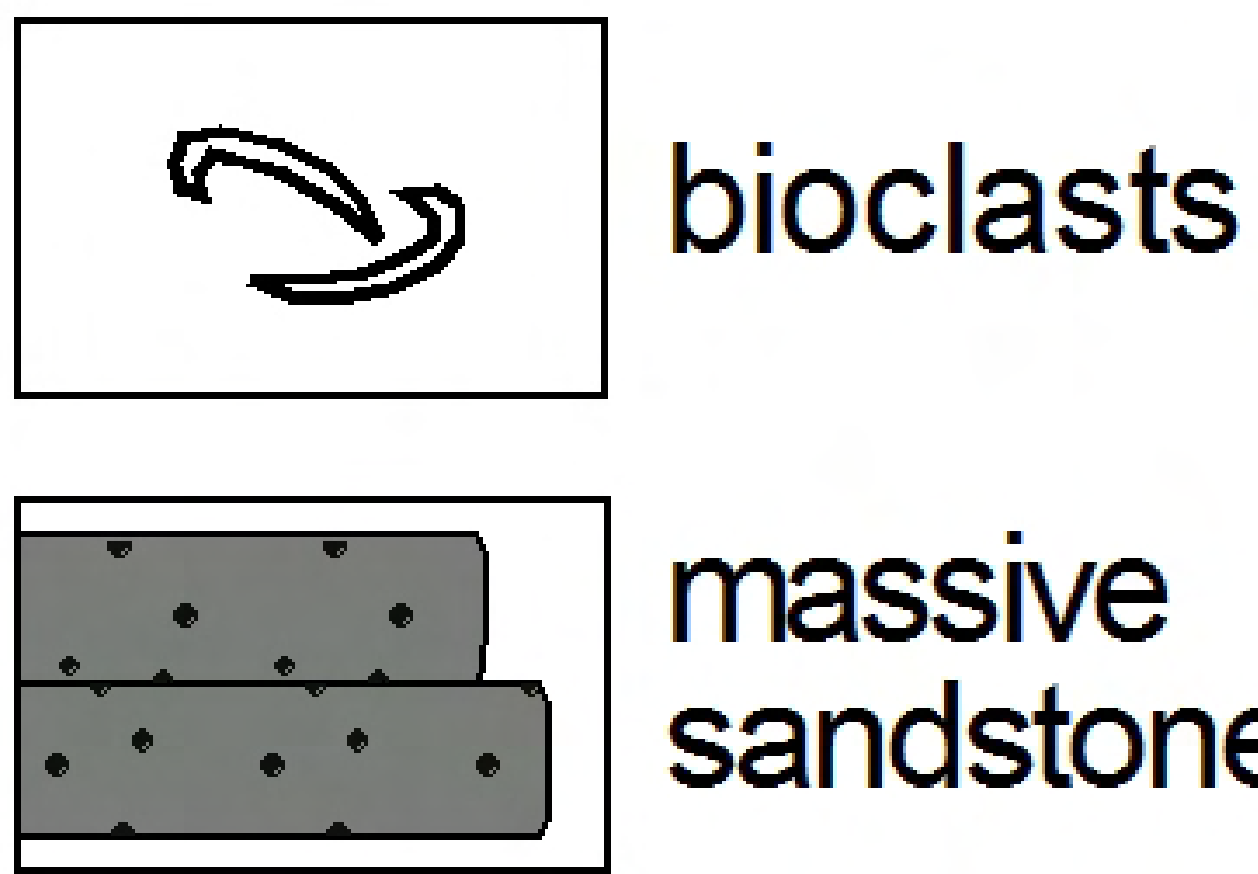

massive sandstones

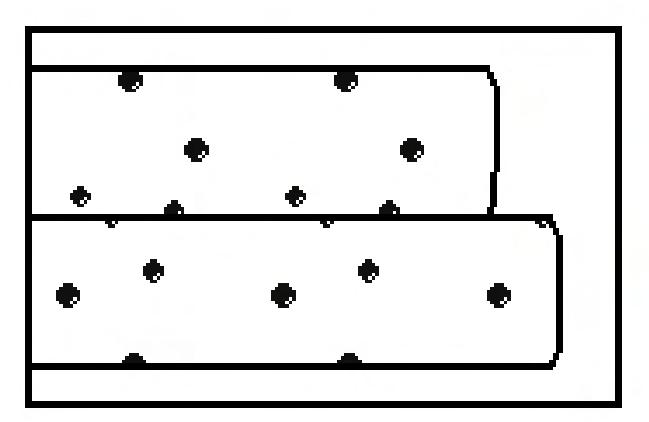

massive bedset

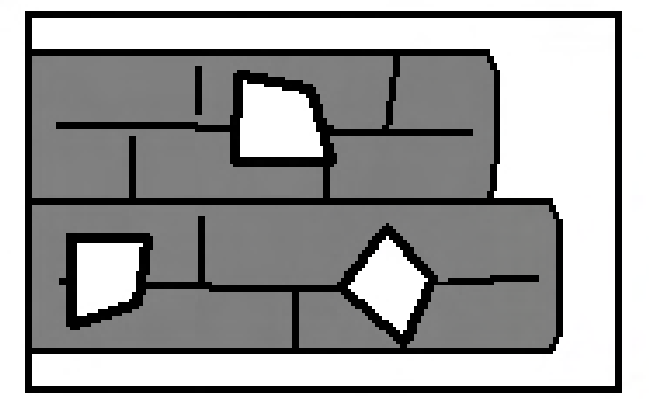

conglomeratic limestones layers or partings

slightly laminated or bedded bedset

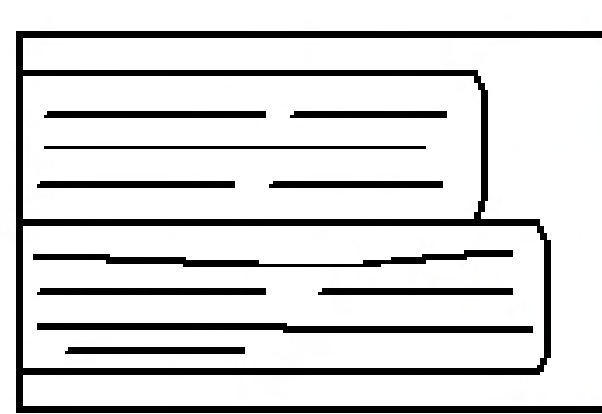

laminated bedset
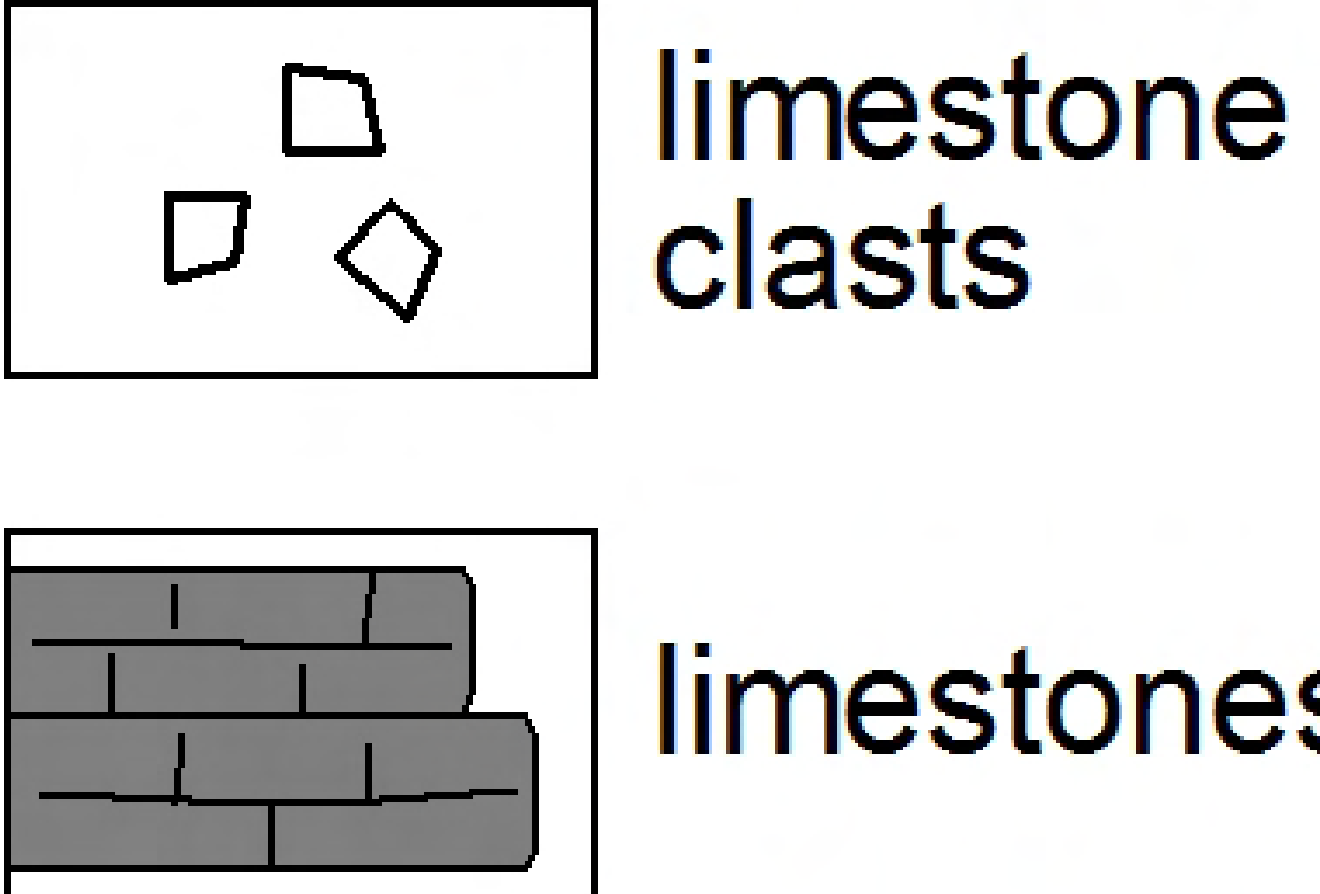

limestones

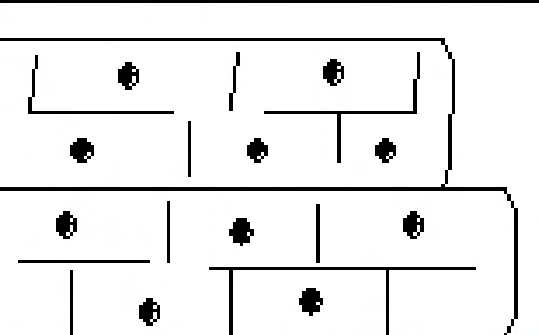

calcareous sandstone bedset 


\section{l.}

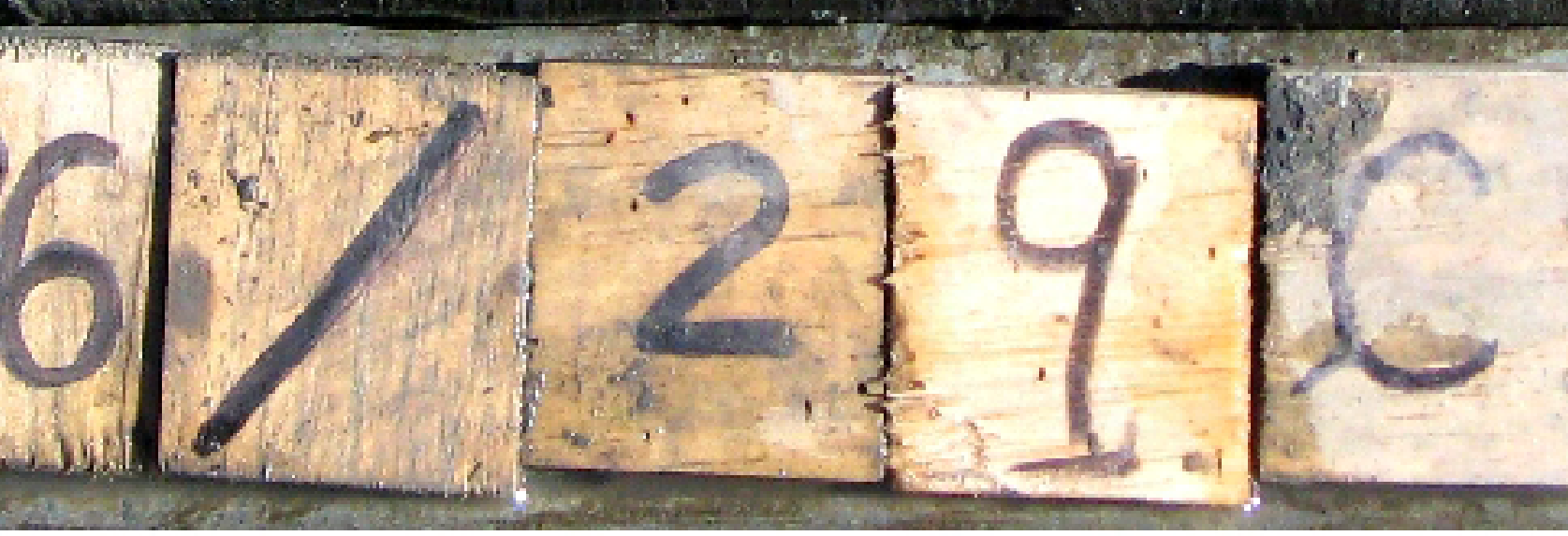

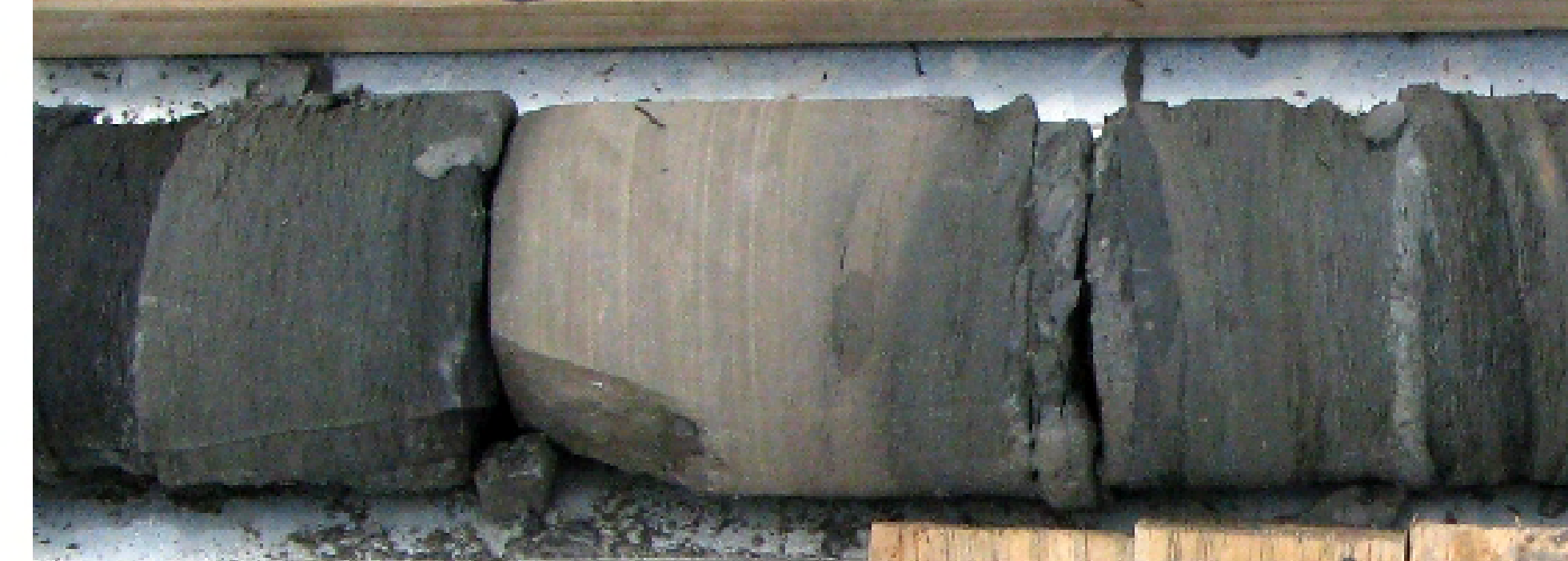

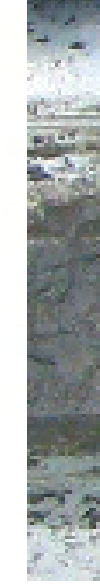

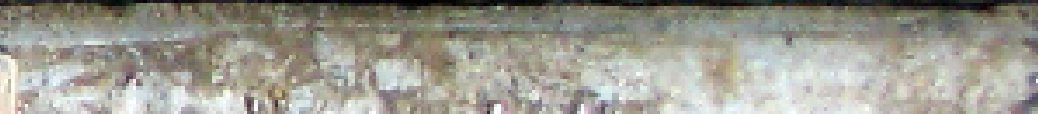

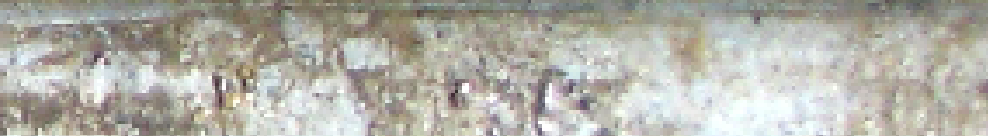

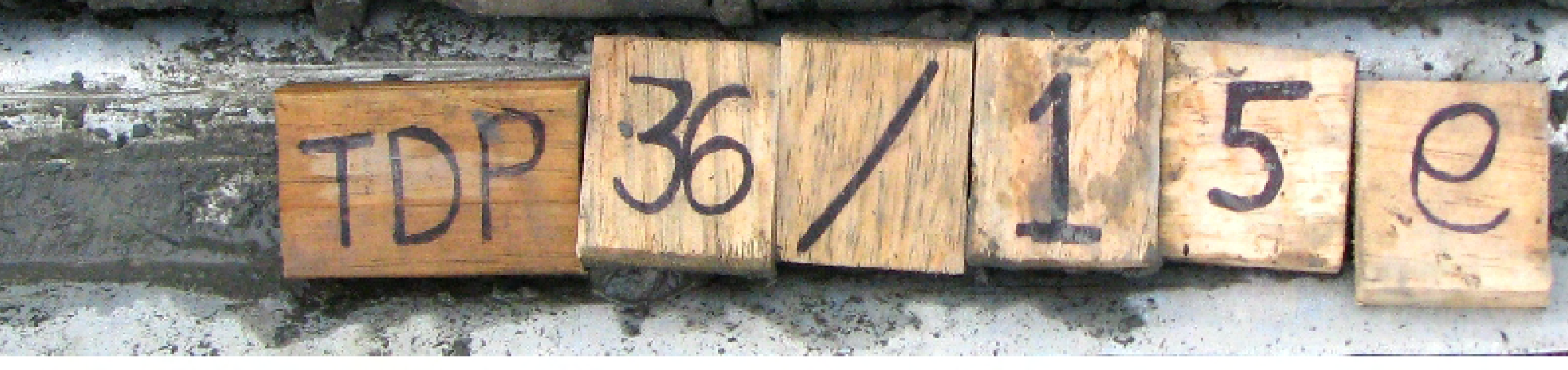

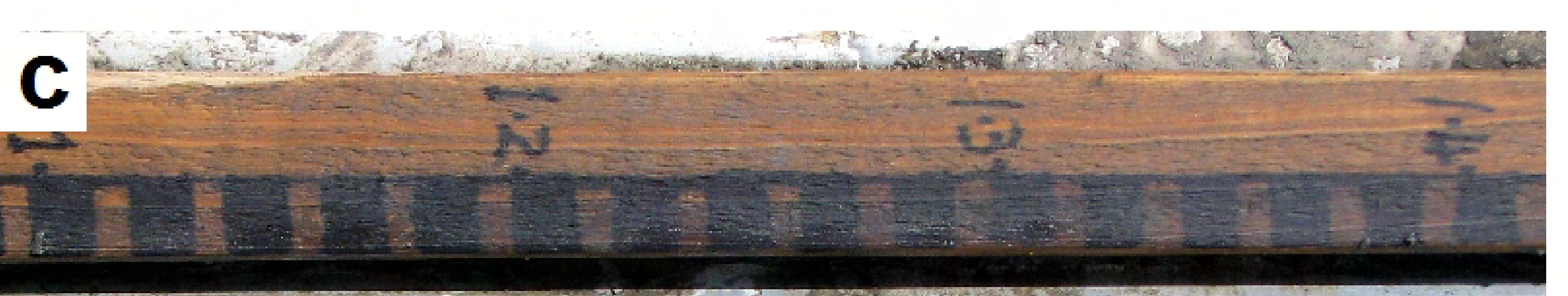

d 운 (x)

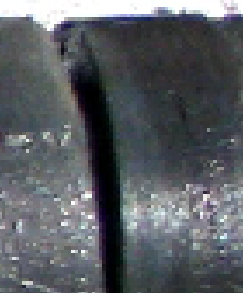

s.

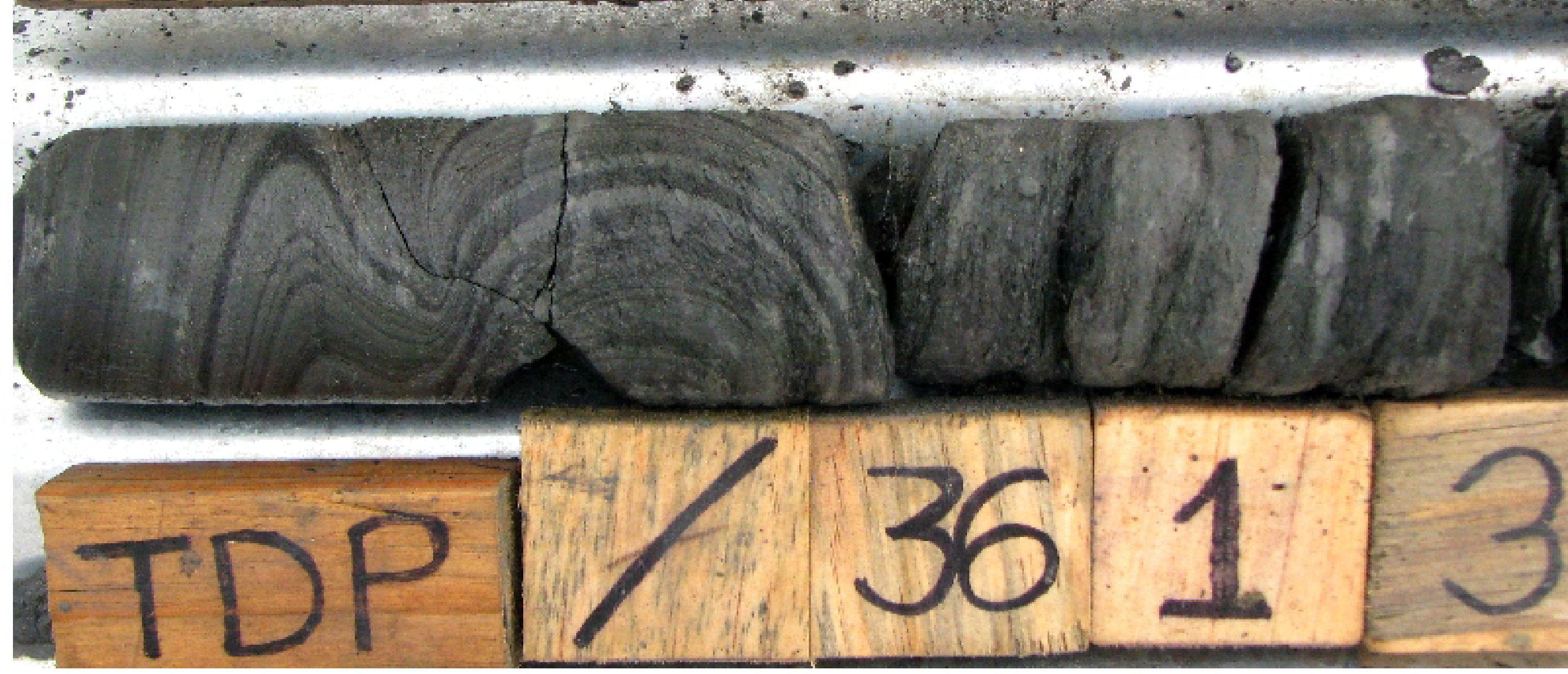

TDP $36 / / 12$ 4 IC $\overline{3}$

$10 \mathbf{f}$

ज

Tr

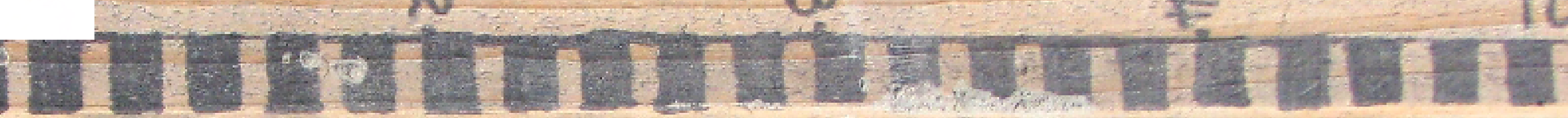
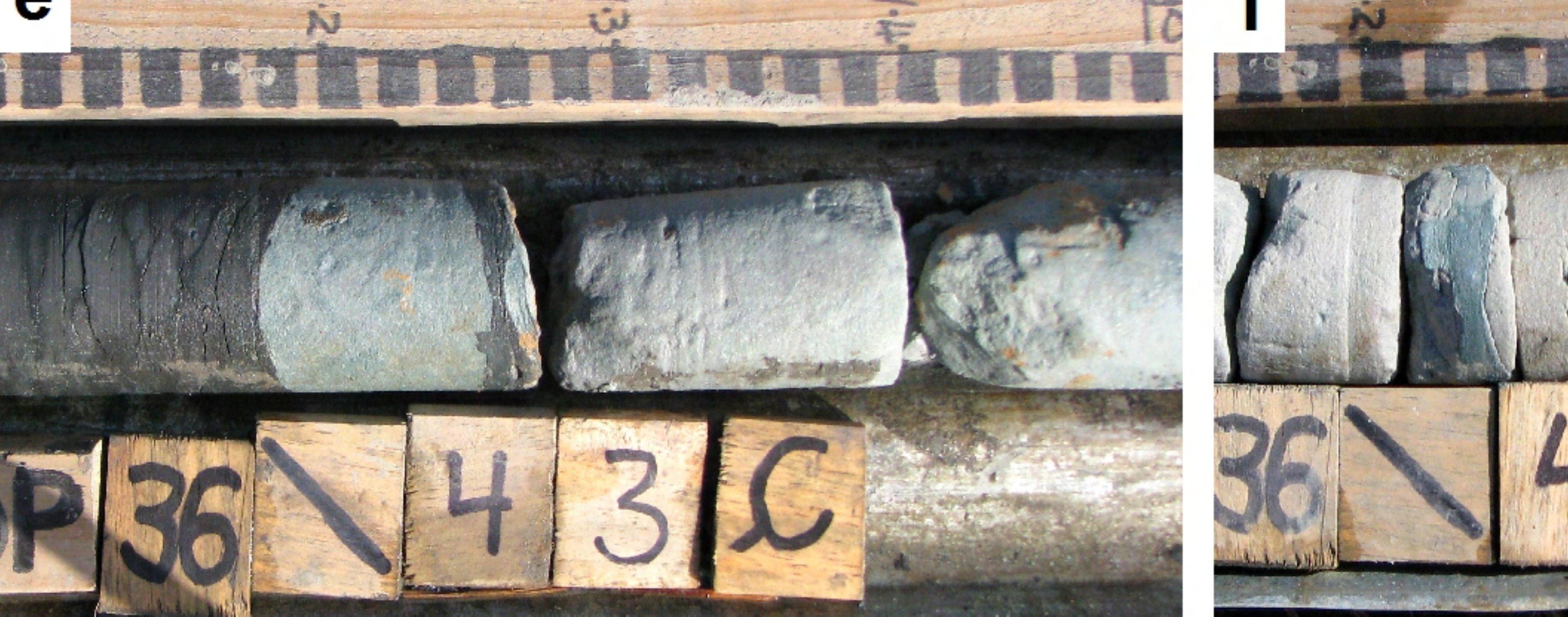

4 blc

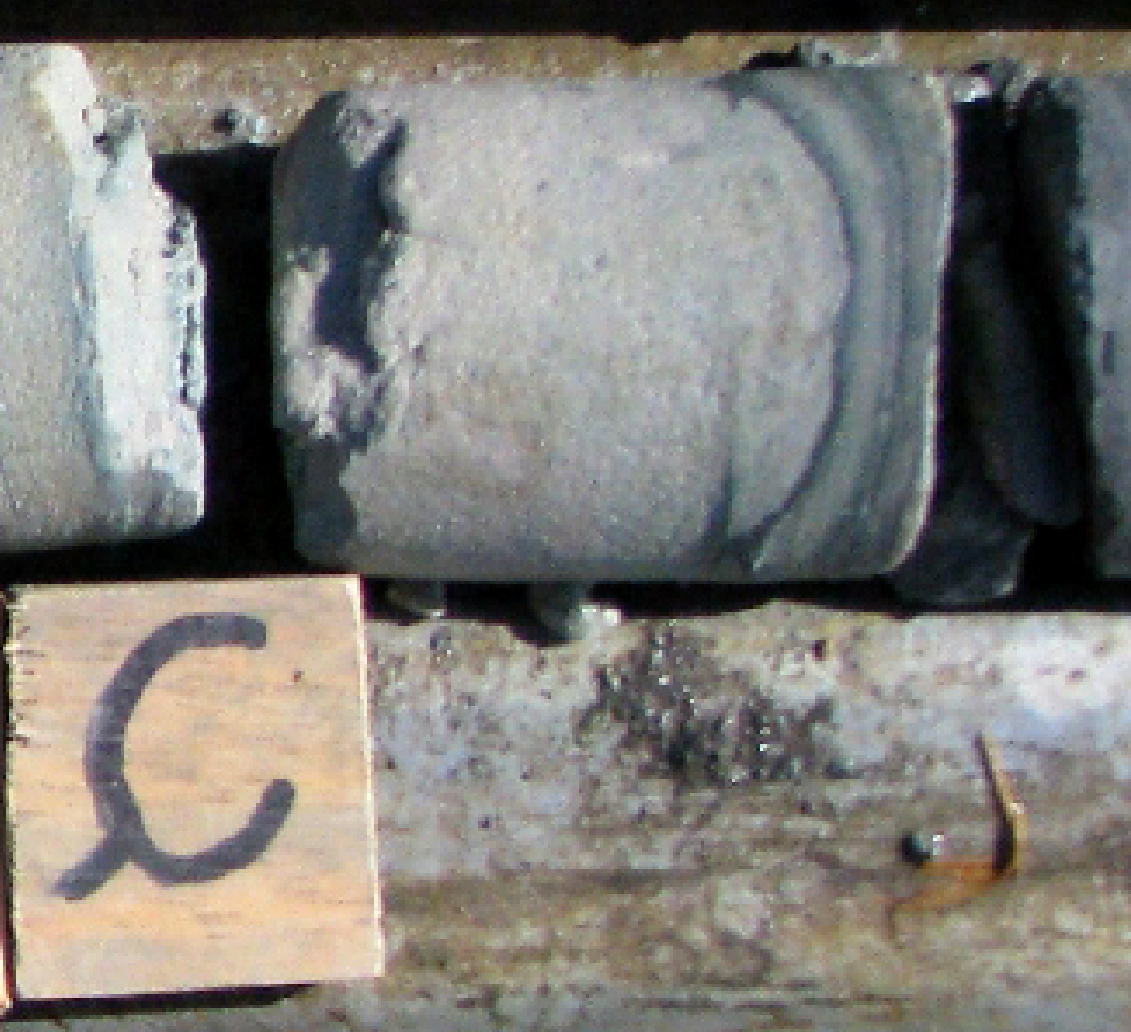




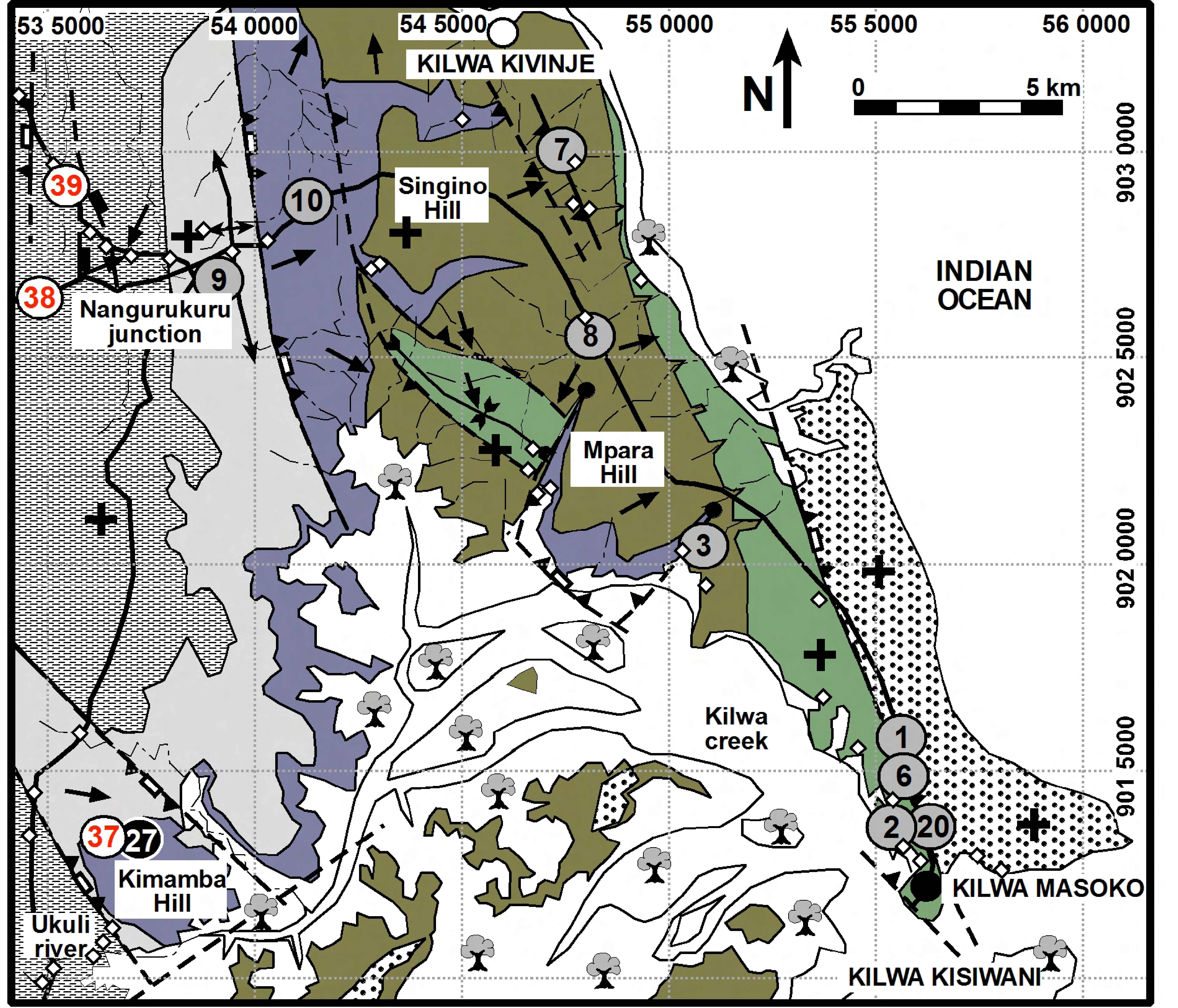

main road

seasonal streams

general dip direction of beds (all $<10^{\circ}$ )

- horizontal bedding

x mangrove swamp

$\diamond$ outcrop samples collected prior to 2007 drilling season
(37) 2009 TDP Site

272008 TDP Site

(2) TDP Site prior

$+\rightarrow$ extensional fault

$4 \Omega 4$ extensional fault contraction
- 1 contractional fault

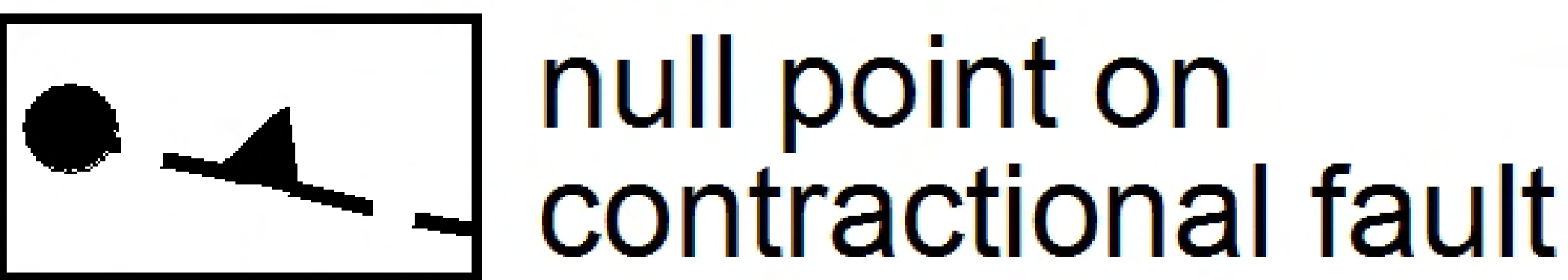
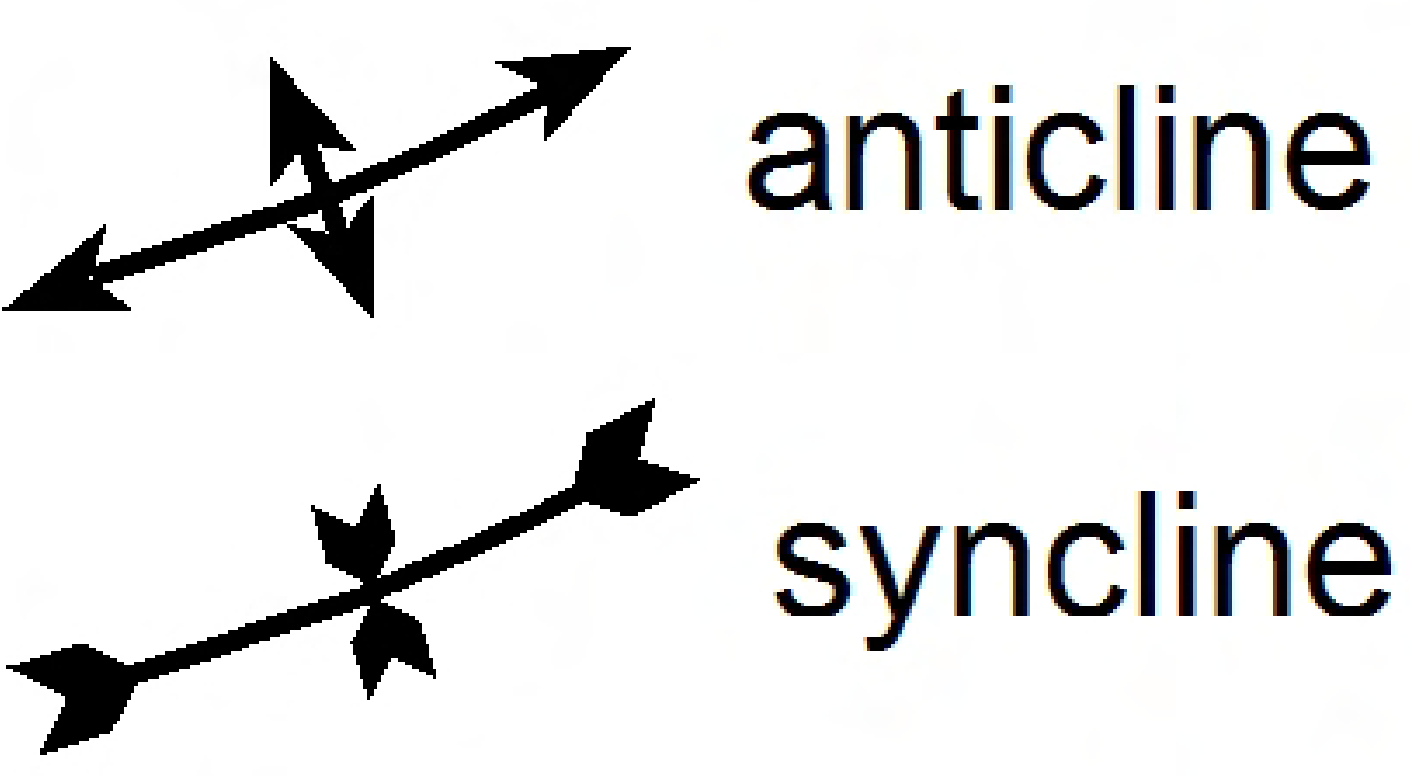
TDP 37 (continuation)

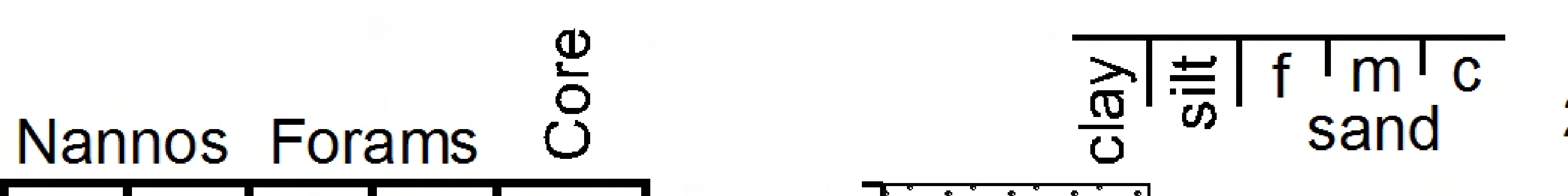
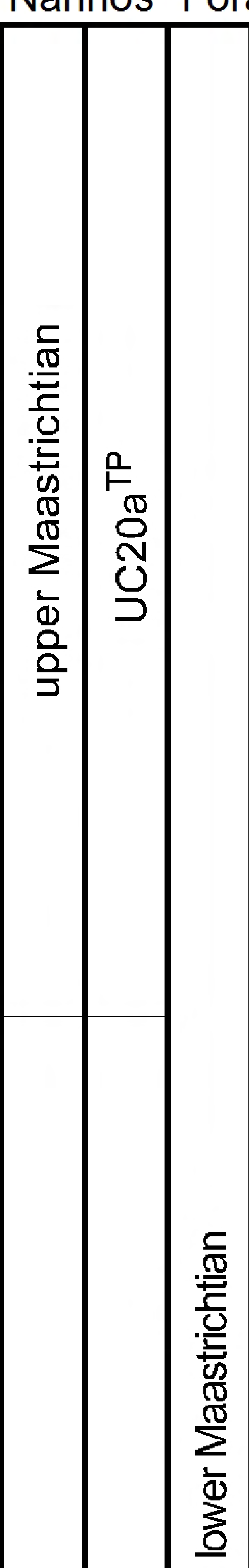

$\cdots \bullet$ \% Carbonate

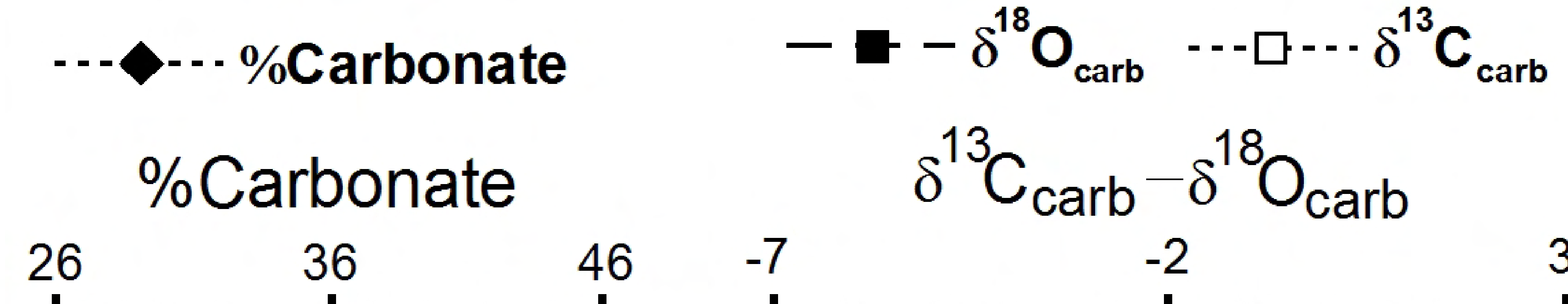




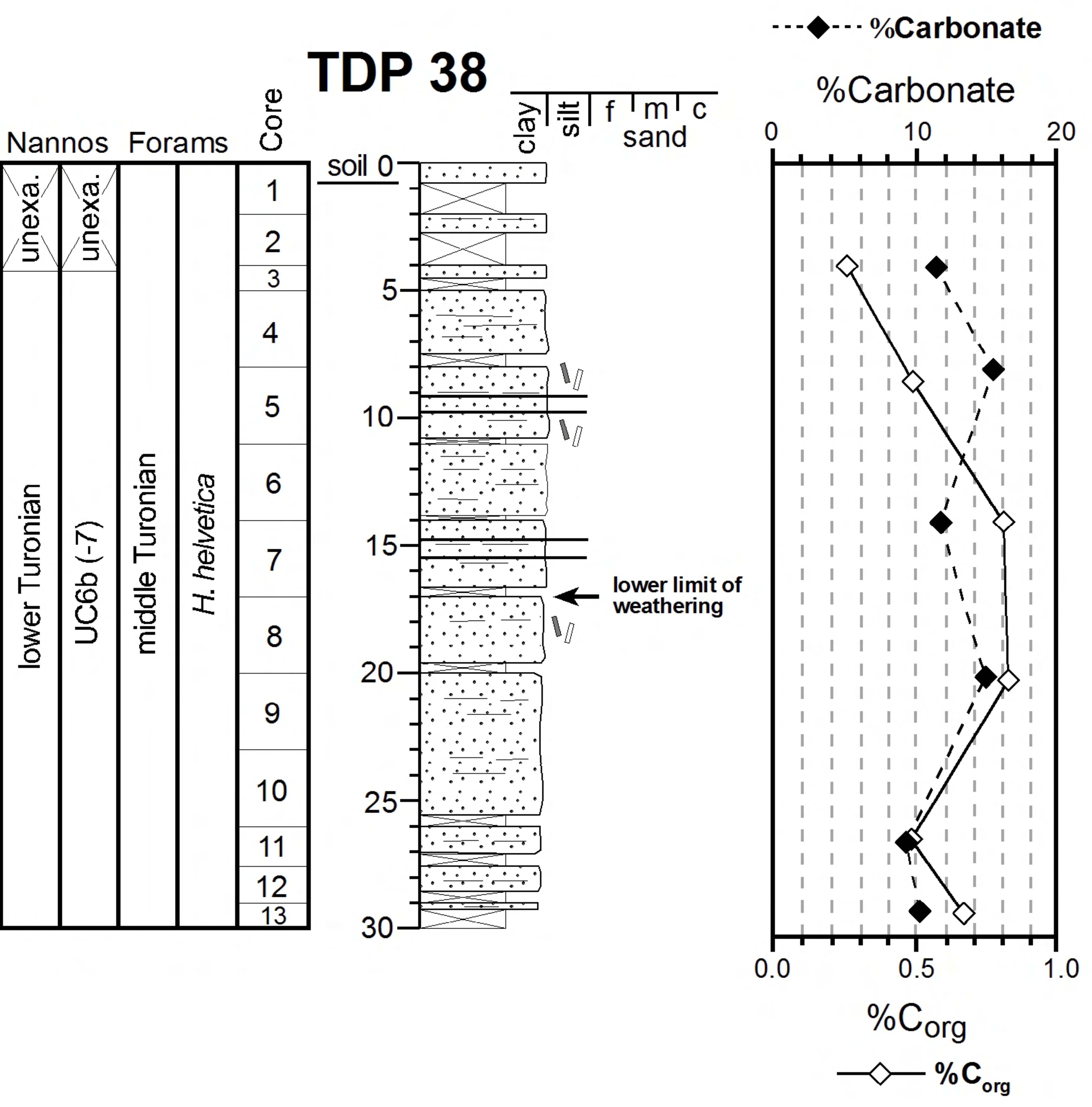




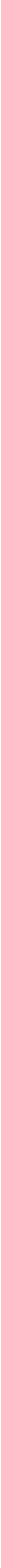


인 $\frac{\pi}{2} 1$

$\frac{07 \because \because \because \because 9}{-\because \because \because \because \because 9}$

25

$\therefore \because \because \because{ }^{2}$

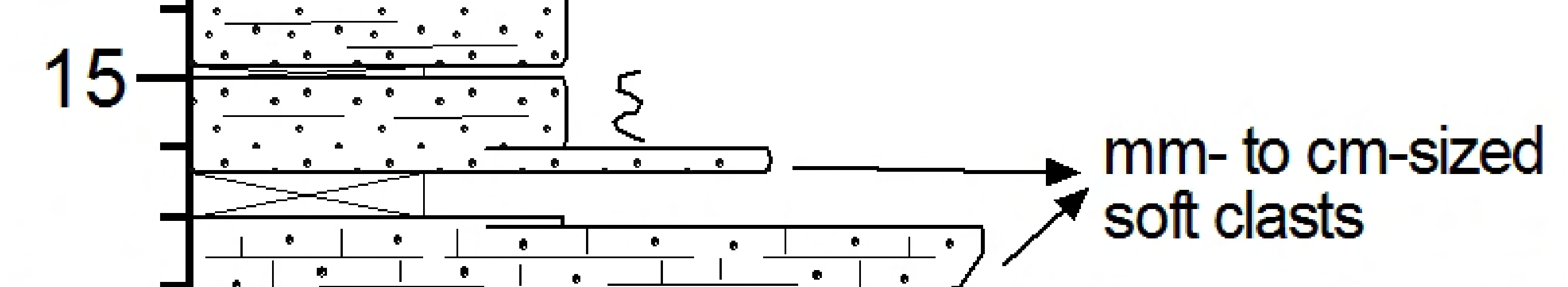

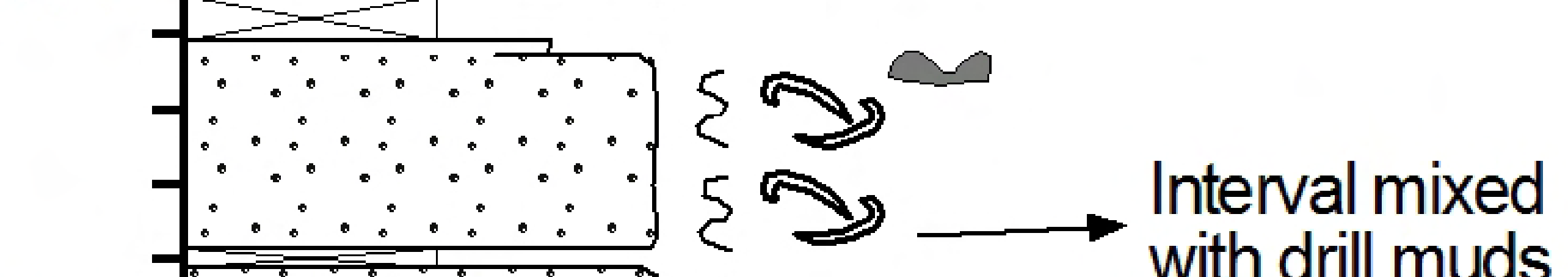

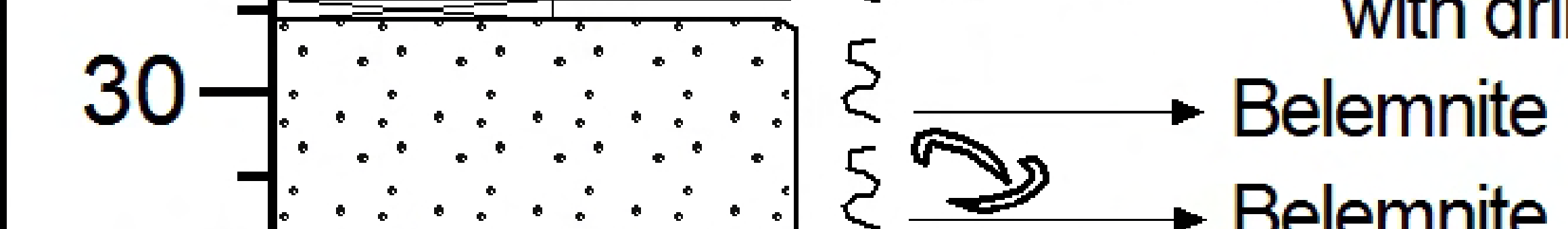

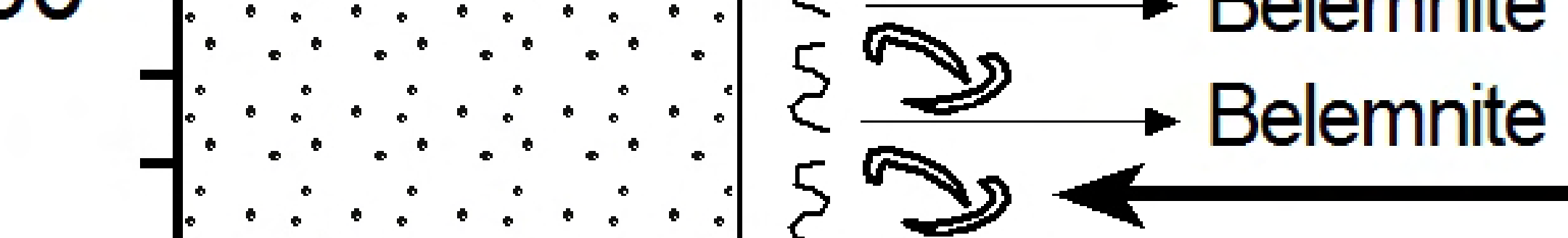

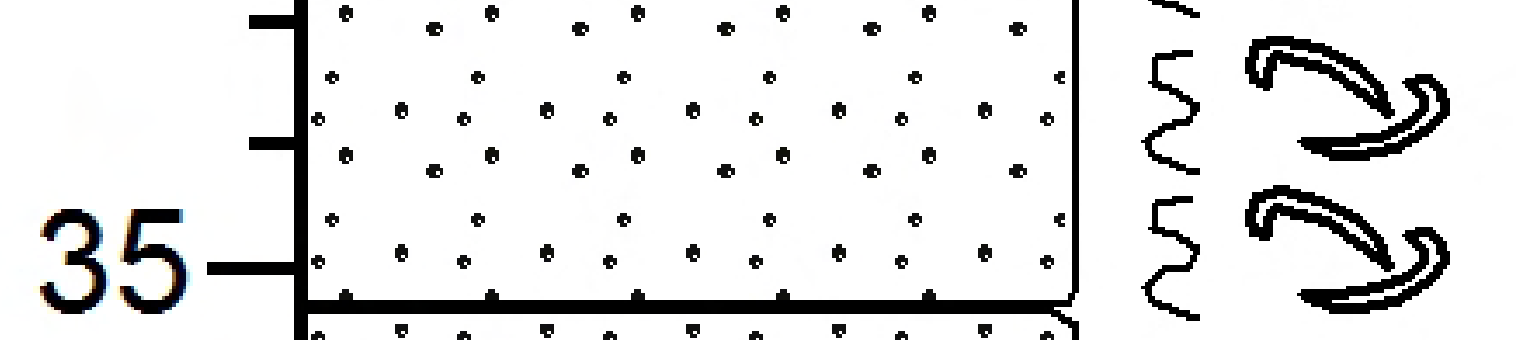

lower limit of weathering

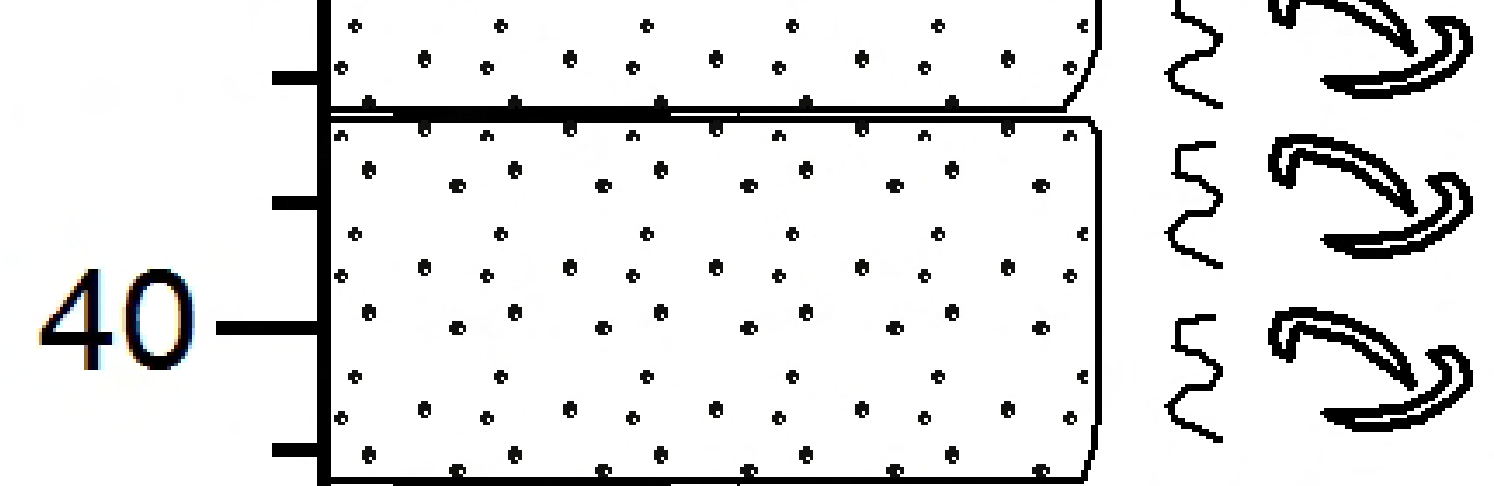

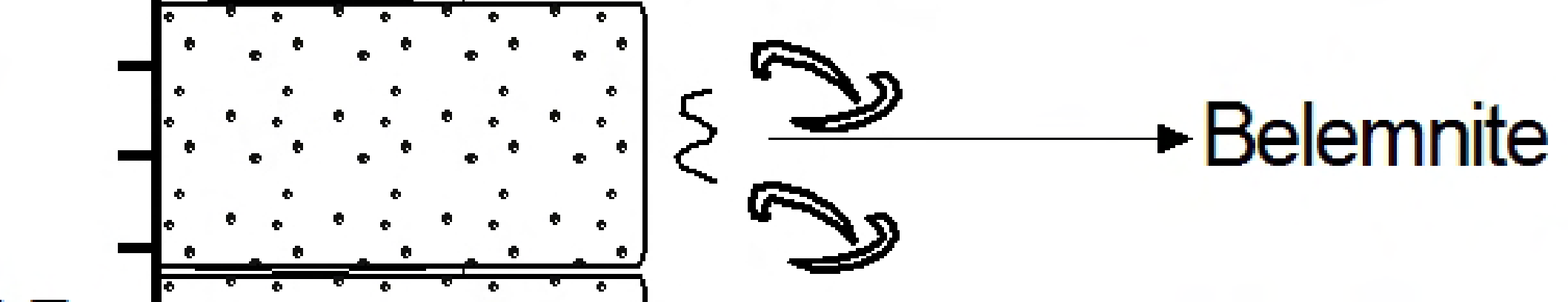

$\longrightarrow$ Ammonite

55

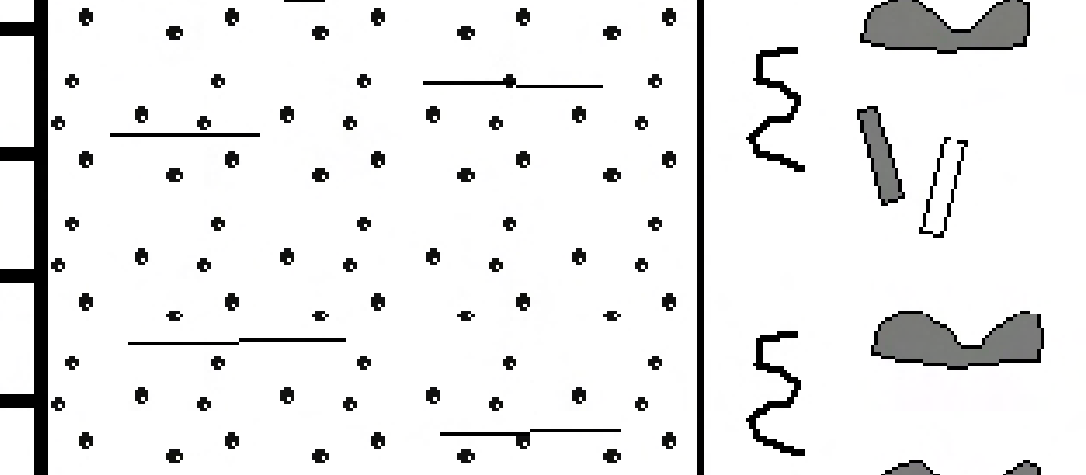

65

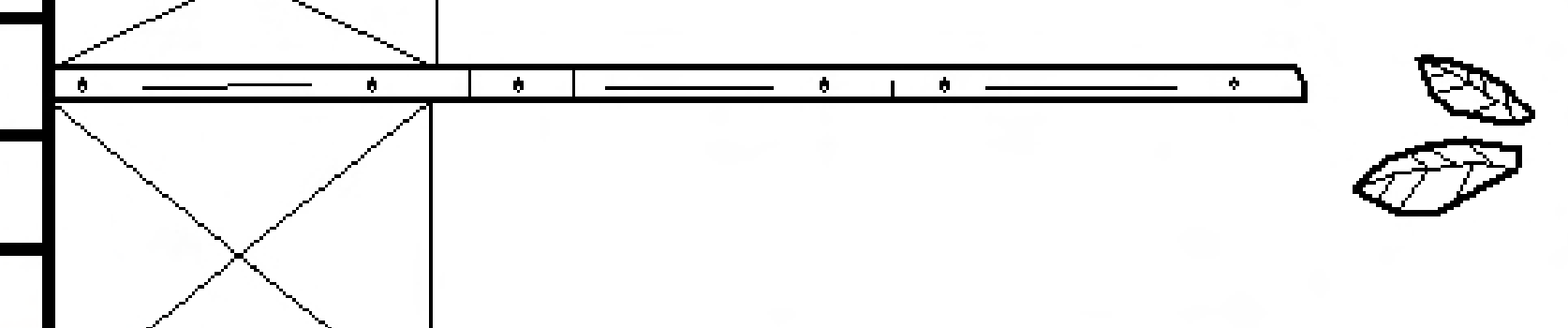

$70-$
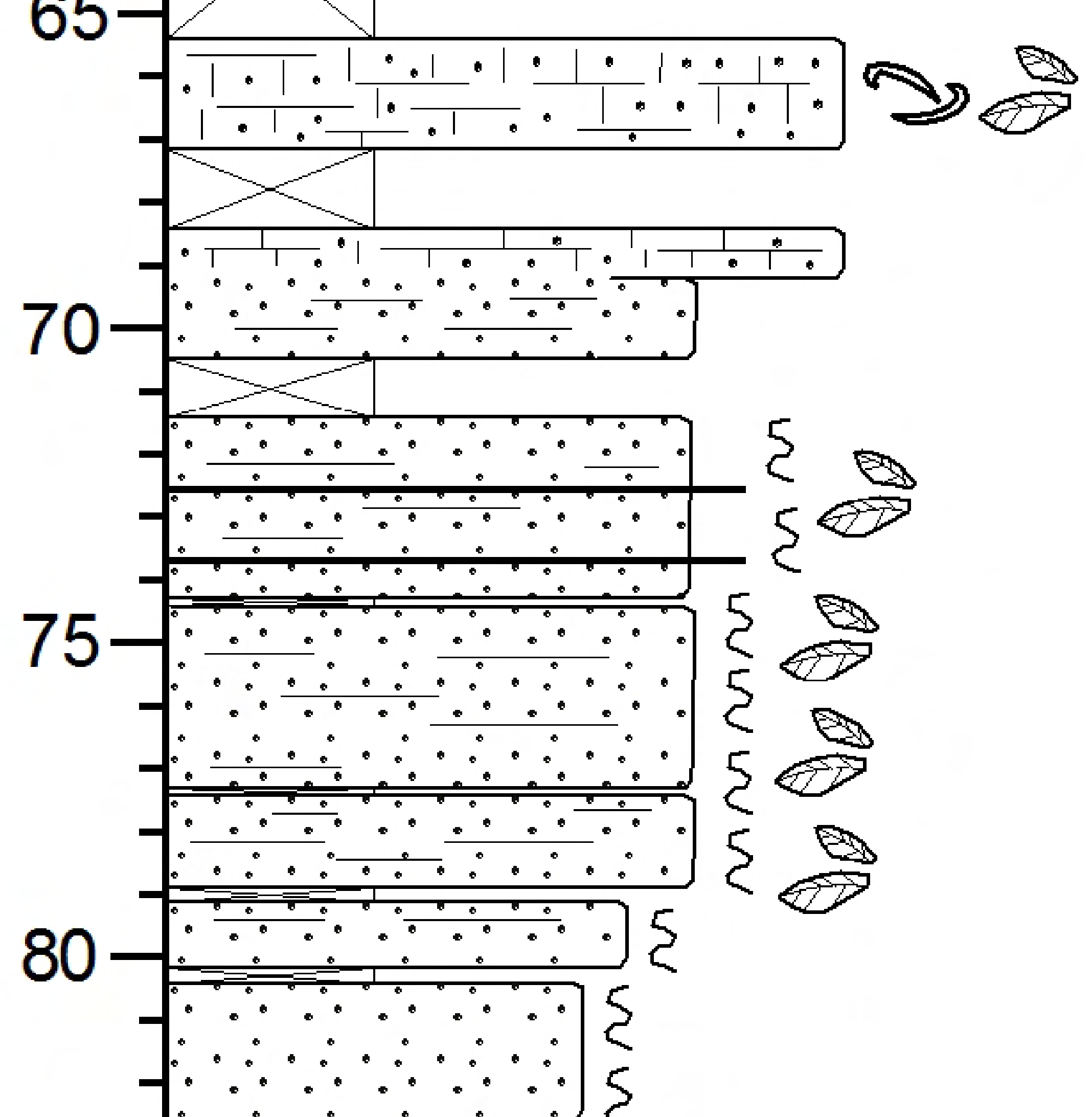


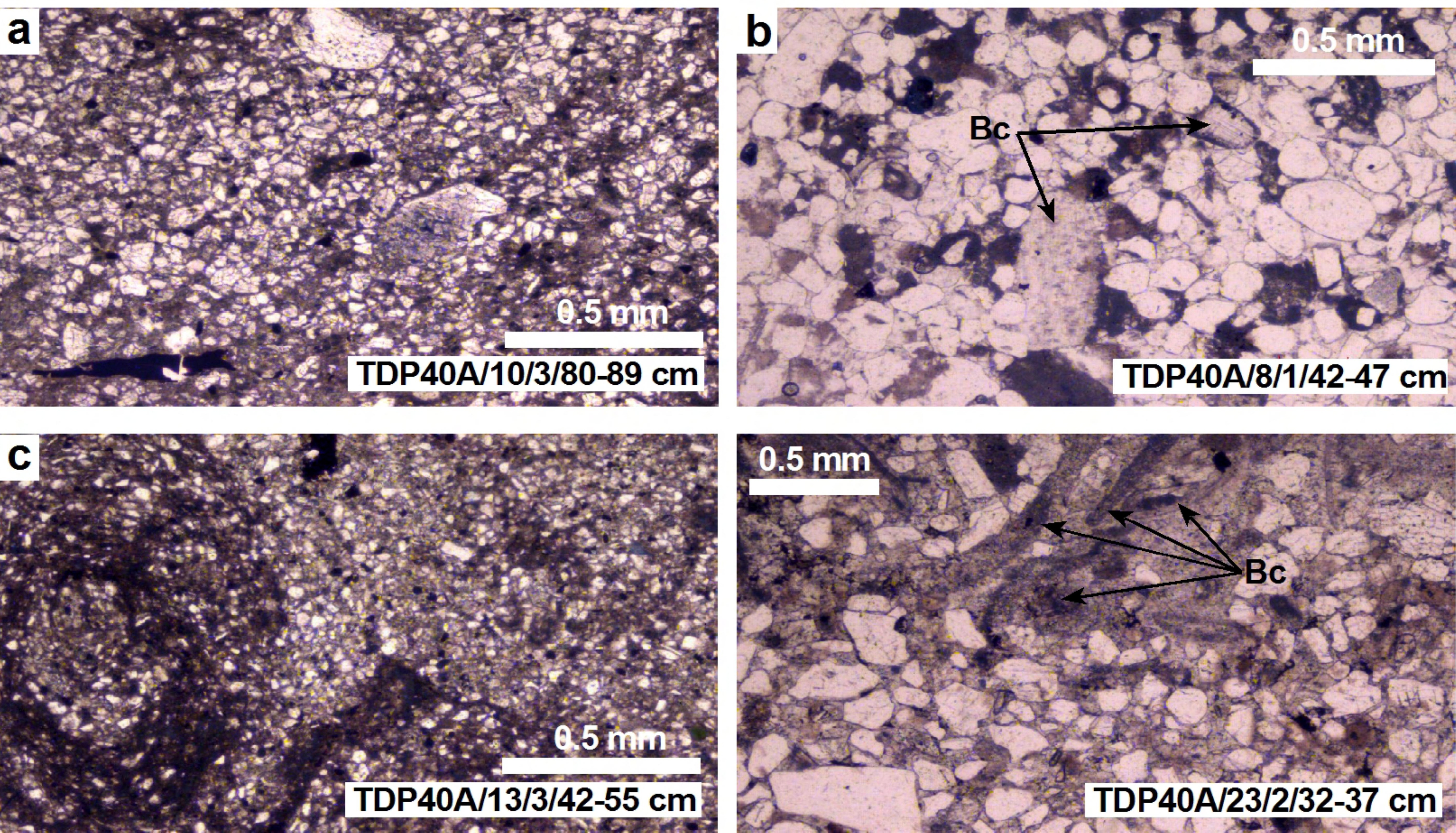


0
0

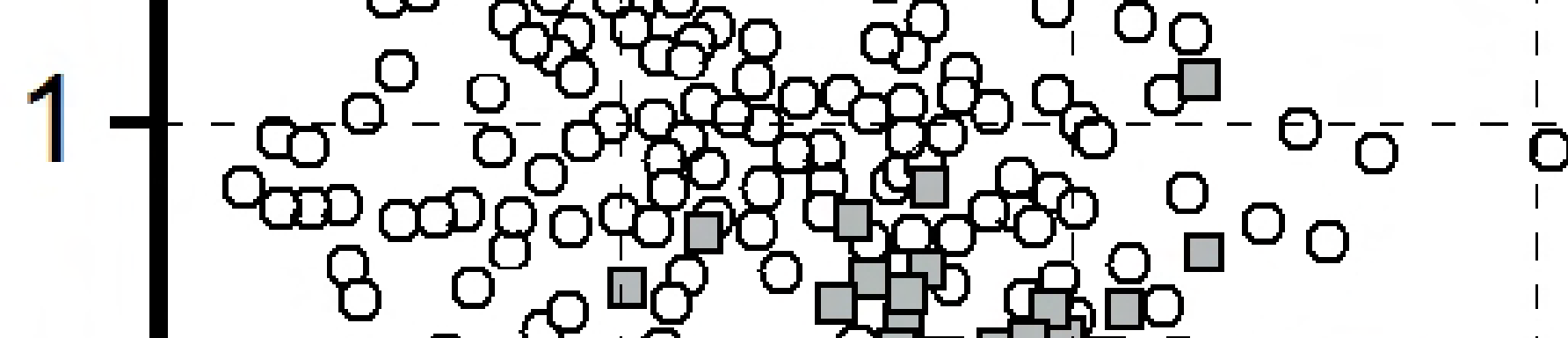

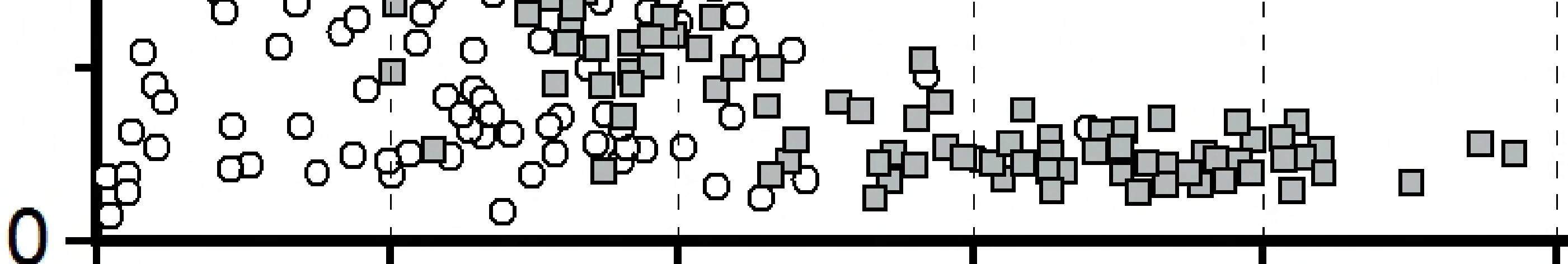

0

10

20

30

40

50

$\% \mathrm{CaCO}_{3}$

$\square$ Nangurukuru Fm

$\mathrm{O}$ Lindi Fm 


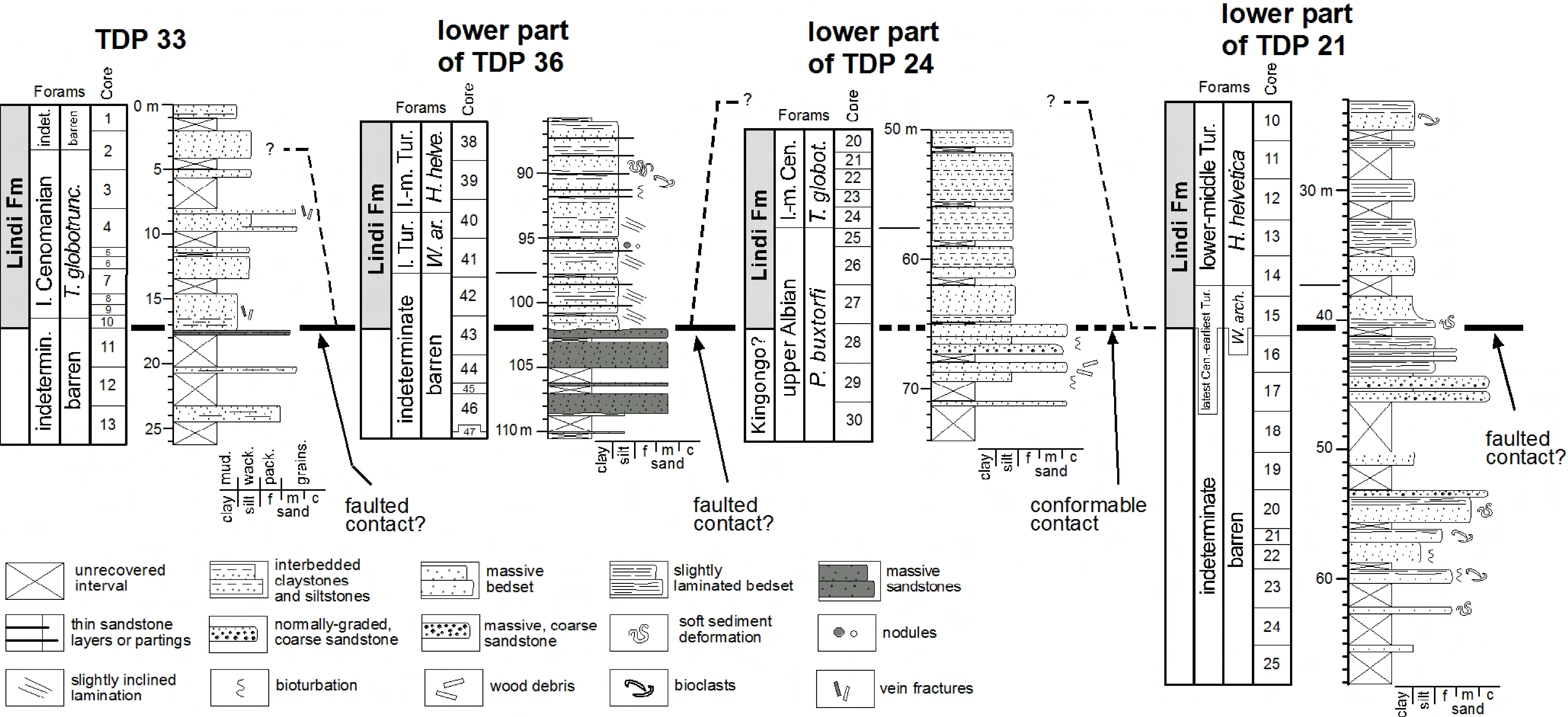

